Федеральное государственное бюджетное обравовательное учреждение высшего образования «Адыгейский государственный университет»

АУТЛЕВА Ф.А., ЧИТАО И.А., ХАТХЕ А.А., СИМБУЛЕТОВА Р.К.

\title{
УЧЕБНО-МЕТОДИЧЕСКОЕ ПОСОБИЕ
}

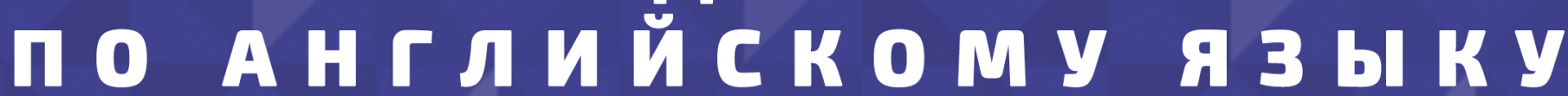

АЛЯ СТУАЕНТОВ 1-2 КУРСОВ

НЕЯЗЫКОВЫХ ФАКУЛЬТЕТОВ 
Аутлева, Ф.А.

Учебно-методическое пособие по английскому языку для студентов 1-2 курсов неязыковых факультетов. [Электронный ресурс]: учебное электронное издание / Ф.А. Аутлева, И.А. Читао, А.А. Хатхе, Р.К. Симбулетова Электрон. дан. (3,8 Мб). - Майкоп: ЭлИТ, 2016. - 1 электрон. опт. диск (CD-R).

doi: 10.18411/elit-010. http://www.dx.doi.org/10.18411/elit-010.

\title{
Публикуется по решению редакционно-издательского совета Адыгейского государственного университета
}

\author{
РЕЦЕНЗЕНТЫ: \\ Пафова Ф.А. - кандидат филологических наук, доцент \\ Таранова Л.А. - кандидат педагогических наук
}

Настоящее пособие предназначено для студентов 1-2 курсов неязыковых факультетов, владеющих основами английской фонетики, грамматики, лексики.

Пособие рассчитано на 180 аудиторных часов.

Материал пособия разделён на вводно-фонетический курс, состоящий из 7 уроков, $и$ основной. Вводный курс охватывает следуюший фонетический материал: алфавит, типь чтения ударных гласных, возможные варианты чтения английских гласных и буквосочетаний с ними, непроизносимые согласные, английские согласные звуки, имеющие несколько вариантов написания, словесное и фразовое ударение. Множественное число и притяжательный падеж существительных, числительные, модальные глаголь, времена неопределённого вида - таков грамматический материал, включённый в вводно-фонетический курс.

Материал основного курса разделён на 5 уроков, посвященных следующим темам: образование (1-2 A, В, C, D), Великобритания, (уроки: 3 A, B, C), столица Великобритании, Aдыгея. 


\section{ОГЛАВЛЕНИЕ}

ПРЕДИСЛОВИЕ .........................................................................................................................................................4

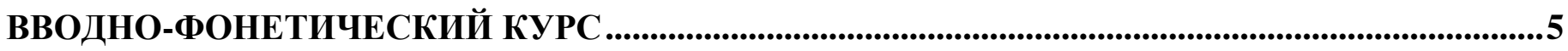

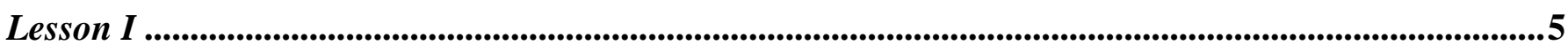

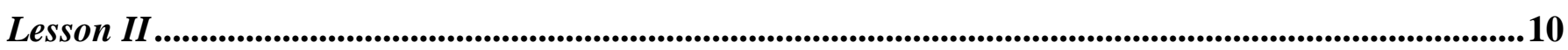

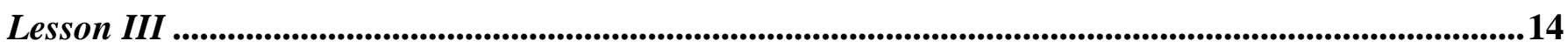

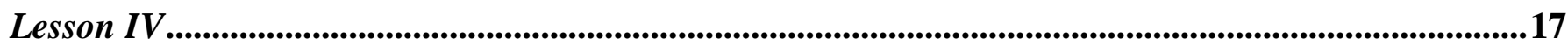

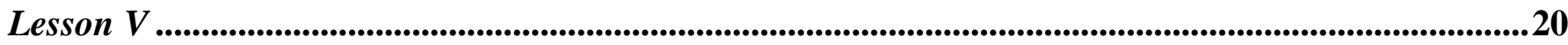

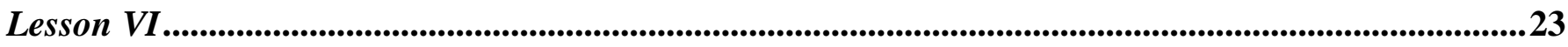

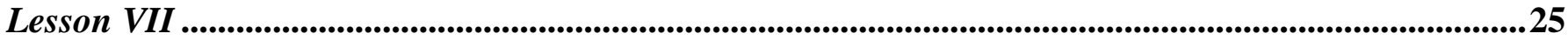

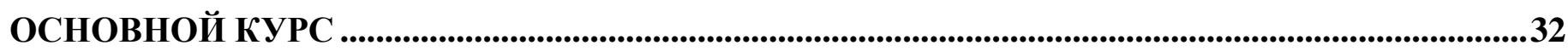

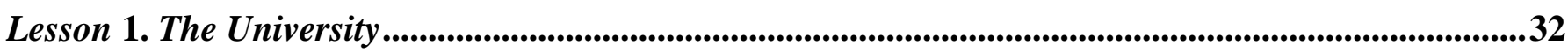

Lesson 2 A. Some Aspects of British Education ....................................................................................................39

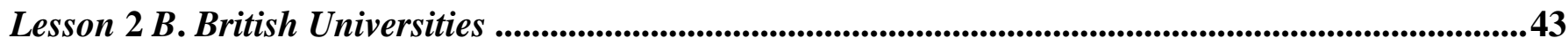

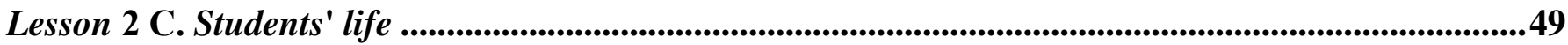

Lesson 2 D. Оксфорд, как он есть ............................................................................................................56

Lesson 3 A. Great Britain. Geographical position ................................................................................60

Lesson 3 B. Great Britain. Economy and largest cities ...................................................................66

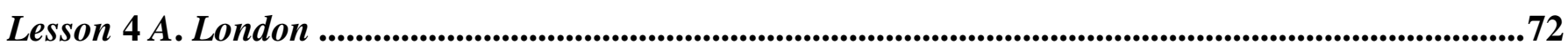

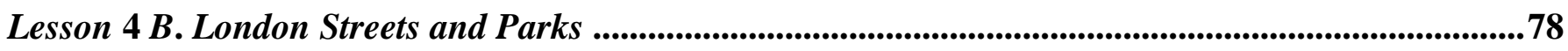

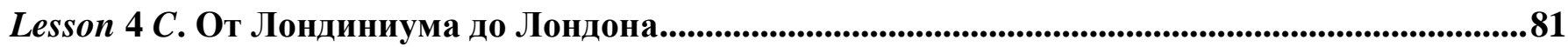

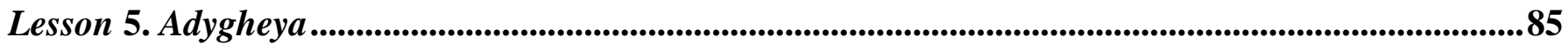

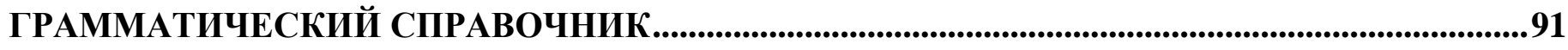

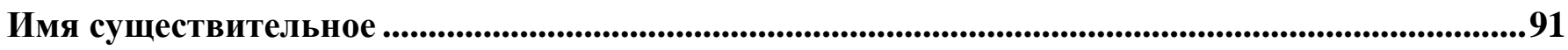

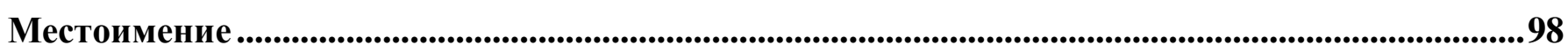

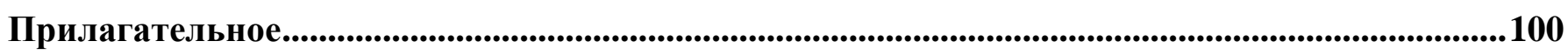

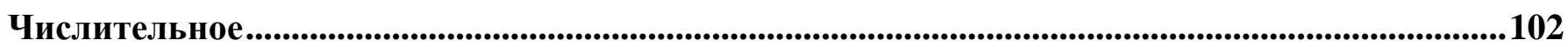

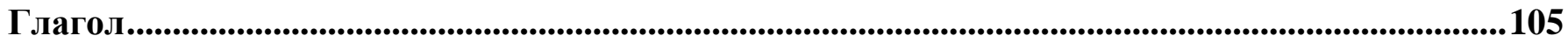

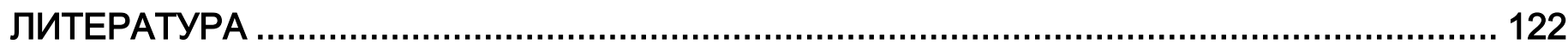




\section{ПРЕДИСЛОВИЕ}

Настоящее пособие предназначено для студентов 1-2 курсов неязыковых факультетов, владеющих основами английской фонетики, грамматики, лексики.

Пособие рассчитано на 180 аудиторных часов.

Материал пособия разделён на вводно-фонетический курс, состоящий из 7 уроков, и основной. Вводный курс охватывает следующий фонетический материал: алфавит, типы чтения ударных гласных, возможные варианты чтения английских гласных и буквосочетаний с ними, непроизносимые согласные, английские согласные звуки, имеющие несколько вариантов написания, словесное и фразовое ударение. Множественное число и притяжательный падеж существительных, числительные, модальные глаголы, времена неопределённого вида - таков грамматический материал, включённый в вводно-фонетический курс.

Материал основного курса разделён на 5 уроков, посвященных следующим темам: образование (1-2 A, B, C, D), Великобритания, (уроки: 3 A, B, С), столица Великобритании, Адыгея.

Каждый урок основного курса состоит из следующих разделов:

1. Предтекстовые упражнения в основном на словообразование с лексическим комментарием и повторение фонетики;

2. Упражнения к тексту: найти производные, синонимы, антонимы,

английские эквиваленты, выразить высказывание одним словом, закончить предложение по тексту, составить предложение из данных слов, заполнить пропуски словами из текста;

3. Упражнения на развитие разговорных навыков: ответить на вопросы, составить диалог, составить аннотацию к русскому тексту и перевести её на английский язык. Последний вид работы вторы включили в отдельный раздел, поскольку рассматривают перевод как дальнейшую ступень (период) обучения, а не средство для раскрытия смысла. Навыки перевода отрабатываются на примерах, заимствованных из общественно-политической и научной литературы;

4. Грамматические упражнения тоже выделены в отдельный раздел. Это позволяет преподавателю строить занятия в зависимости от уровня подготовленности студентов и количества часов, отведённых для занятий по английскому языку на данном факультете.

Каждый грамматический раздел завершается упражнениями на перевод с русского языка на английский для закрепления грамматических трудностей. В некоторых уроках есть упражнения на повторение грамматического материала, изученного раньше.

Грамматический курс изучается параллельно с учебными текстами и охватывает следующие аспекты: времена, залог, неличные формы глагола (Participle, Infinitive).

Тексты и упражнения интересны в познавательном отношении и стимулируют умственную активность студентов, побуждая к обсуждению.

Данная работа явилась результатом многолетнего труда коллектива авторовпреподавателей кафедры иностранных языков и проверена практикой преподавания на естественном, физическом, математическом и других факультетах. 


\section{ВВОДНО-ФОНЕТИЧЕСКИЙ КУРС}

\section{Lesson I}

Phonetics: ABC; 4 types of stressed vowels reading; combinations with " $h "$; word stress.

Grammar: Personal, possessive, demonstrative pronouns; "to be" in the Present

Indefinite, its functions in the sentence (notional, link-verb, auxiliary, modal verb)

\begin{tabular}{|c|c|c|c|}
\hline Буквы & $\begin{array}{c}\text { Алфавитное } \\
\text { название }\end{array}$ & Чтение & Примеры \\
\hline$A a$ & {$[e i]$} & & \\
\hline $\begin{array}{l}B b \\
C c\end{array}$ & [bi:] & $\begin{array}{c}{[b]} \\
{[s] \text { before e,i,y; }} \\
{[[] \text { before } 2 \text { vowels }}\end{array}$ & $\begin{array}{l}\text { Biology, book, club } \\
\text { city, peace, principle } \\
\text { social, official }\end{array}$ \\
\hline & [si:] & $\begin{array}{l}{[\mathrm{k}]} \\
[t]]\end{array}$ & Canada, come, mercury concerto, cembalo \\
\hline$D d$ & [di] & {$[d]$} & day, student, adult \\
\hline $\mathrm{Ee}$ & {$[i]$} & & \\
\hline$F f$ & [ef] & $\begin{array}{l}{[f]} \\
{[g]}\end{array}$ & $\begin{array}{l}\text { family, } \text { faculty } \\
\text { go, grant }\end{array}$ \\
\hline Gg & [dzii] & $\begin{array}{l}\text { [d]] before } e, i, y \text { in words of } \\
\text { Greek and Latin orgin: }\end{array}$ & Geography, general \\
\hline $\begin{array}{c}H h \\
\text { li }\end{array}$ & $\begin{array}{l}{[\text { eit]] }} \\
{[a i]}\end{array}$ & {$[h]$} & have, hostel \\
\hline$J j$ & ['] & [d3] & join, enjoy, joint \\
\hline Kk & [kei] & {$[k]$} & peak, work, king \\
\hline $\boldsymbol{L I}$ & {$[e l]$} & [1] & language, tell, library \\
\hline$M m$ & [em] & {$[m]$} & Moscow, mountain, myth \\
\hline$N n$ & {$[e n]$} & {$[n]$} & North, institute \\
\hline Oo & [ou] & & \\
\hline$P p$ & {$[p i]$} & {$[\boldsymbol{P}]$} & people, parents \\
\hline$Q q$ & [kju:] & $q u[k w]$ & quick, square \\
\hline $\boldsymbol{R} r$ & {$[a: r]$} & {$[r]$} & $\begin{array}{l}\text { rule, respond, right } \\
\text { system, student }\end{array}$ \\
\hline Ss & [es] & $\begin{array}{l}\text { [z] after vowels, voiced } \\
\text { consonants, intervocal: }\end{array}$ & goes, physics \\
\hline $\begin{array}{c}T t \\
U u\end{array}$ & $\begin{array}{l}{[t i]} \\
{[j u:]}\end{array}$ & {$[t]$} & unity, trade \\
\hline$V v$ & {$[v i]$} & {$[v]$} & victory, live \\
\hline$W w$ & ['d/Nblju:] & $\begin{array}{l}{[w]} \\
{[k s]}\end{array}$ & $\begin{array}{l}\text { winter, water } \\
\text { exercise, fox }\end{array}$ \\
\hline$X x$ & [eks] & {$[\Gamma]$} & xerox [ziorəks], \\
\hline Yy & [wai] & [gz] before stressed vowels: & $\begin{array}{l}\text { xylophone, xylonite } \\
\text { exam, example }\end{array}$ \\
\hline$Z z$ & [zed] & [z] & zero, zone \\
\hline
\end{tabular}


some combinations with $-h$ -

[t]] child, chair

[k] chemistry, architect

ch [d3] spinach [spinid3], sandwich ['sǽnwid3], Greenich [grinid3]

[S] chauffeur [ Joufə], ruche [ru:S], chandelier [Sǽndi'lie]

канделябр, люстра,

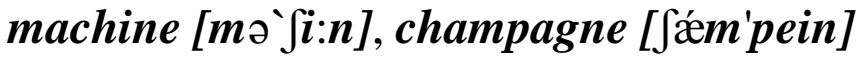

ph [f] physics, phone

sh [J] share, shape

th $[\Theta]$ think, thank

[ð] with, the, this, those, then

wh+o [h] who, whom, whole

wh+e,i,y,a [w] when, white, what

four types of stressed vowels reading

\begin{tabular}{|c|c|c|c|c|}
\hline Vowels & $\begin{array}{l}\text { 1-st type of } \\
\text { reading (open) }\end{array}$ & $\begin{array}{l}\text { 2- type of reading } \\
\text { (closed })\end{array}$ & $\begin{array}{c}\text { III- type }(-r+ \\
\text { con })\end{array}$ & $I V-$ type $(-r+$ vowel $)$ \\
\hline$A a$ & $\begin{array}{l}\text { [ei] name } \\
\text { fate }\end{array}$ & $\begin{array}{l}\text { [ǽ] land } \\
\text { fat, map }\end{array}$ & $\begin{array}{l}{[a:] c a r} \\
\text { star }\end{array}$ & $\begin{array}{l}{[\varepsilon ə] \text { care }} \\
\text { stare }\end{array}$ \\
\hline $\mathbf{E e}$ & $\begin{array}{l}\text { [i:] she } \\
\text { he }\end{array}$ & $\begin{array}{l}{[e] \text { ten }} \\
\text { extend }\end{array}$ & $\begin{array}{l}\text { [॰:] her } \\
\text { mercury }\end{array}$ & $\begin{array}{l}\text { [iכ] here } \\
\text { severe }\end{array}$ \\
\hline $\begin{array}{l}I i \\
Y y\end{array}$ & $\begin{array}{c}\text { [ai] type } \\
\text { tide }\end{array}$ & $\begin{array}{r}{[i] \operatorname{six}} \\
\text { myth }\end{array}$ & $\begin{array}{l}\text { [ə:] girl } \\
\text { bird }\end{array}$ & $\begin{array}{l}\text { [aio] iron } \\
\text { tired }\end{array}$ \\
\hline Oo & $\begin{array}{c}{[o u] \text { pole }} \\
\text { go }\end{array}$ & $\begin{array}{l}\text { [o] long } \\
\text { rock }\end{array}$ & $\begin{array}{l}\text { [о:] North } \\
\text { sport }\end{array}$ & $\begin{array}{l}\text { [0:] more } \\
\text { core }\end{array}$ \\
\hline $\boldsymbol{U} \boldsymbol{u}$ & $\begin{array}{c}\text { [ju:] student } \\
\text { music }\end{array}$ & $\underset{\text { bus }}{[\wedge] \text { must }}$ & $\begin{array}{l}\text { [ə:] turn } \\
\text { surface }\end{array}$ & $\begin{array}{c}\text { [juə] cure } \\
\text { pure } \\
\text { secure murial }\end{array}$ \\
\hline
\end{tabular}




\section{Словесное ударение}

- выделение одного или двух слогов среди других.

В двухсложных словах ударение падает на 2-ой слог с конца. college ['kolidz] summer ['s^mə]

vital ['vaitl] navy ['neivi]

В трёхсложных словах ударение падает на 3-й слог с конца, при этом гласная ударного слога читается как в закрытом слоге.

'mineral ['minərəl] elephant ['elifənt]

В многосложных словах ударение падает не только на 3-й слог, но и на 5-й, 7-й, т.е. на каждый третий слог, считая от предшествующего третьего. Один слог имеет главное ударение, другой - второстепенное.

responsibility [risponsə'biliti]

В словах, оканчивающихся на tion, ic [al], ударение падает на слог, предшествующий суффиксу.

restore [ris'to:]

restoration [restorei]n]

Хотя глагольные суффиксы ate, y, ize не ударны, гласный звук в них не редуцируется.

to deligate ['deligeit] a deligate ['deligit] существительное,

to decorate, to occupy, to centralize

\section{Phonetic Exercises}

Ex. I. What letter is the following?

[ei]

A [ai],

[i:]

[dzei]

G [dzi:]

[eit $\left.\int\right]$

[dzi:]

$J$ [dzei]

[eit]] [wai|

I [ai]

[ei]

[ju:]

W [wai]

['d $\wedge$ bliu: ]

[dzi:]

H [eks]

[eit]] [i:]

E [ai]

[ei]

[vi:]

V [ju:]

[wai] [i:]

$\begin{array}{ll}U & {[j u:]}\end{array}$

[wai]

[wai]

Y [ju:]

[ai] [si:]

S [es]

[eks]

[es]

C [si:]

[eks]

Ex. II. Which letter is the following?
[dzi]
$\begin{array}{lll}B & & S \\ C & \text { [si:] } & C\end{array}$
$\boldsymbol{A} \quad \boldsymbol{A}$
$A \quad G$
G $\quad \boldsymbol{Y}$
$Y \quad U$
$\begin{array}{ll}U & W \\ H & \end{array}$
$\boldsymbol{G} \quad \boldsymbol{X}$
$\begin{array}{lll}I & {[i:]} & E \\ Y & & Y\end{array}$
$\begin{array}{lll}J & {[j u:]} & I \\ Q & & U\end{array}$
$\begin{array}{ll}U^{[}[\text {eit] } & H \\ J\end{array}$
Y
$Y \quad Q$
$\begin{array}{lll}J & V\end{array}$ 
Ex. III. Read the following words. Mind the underlined letter.

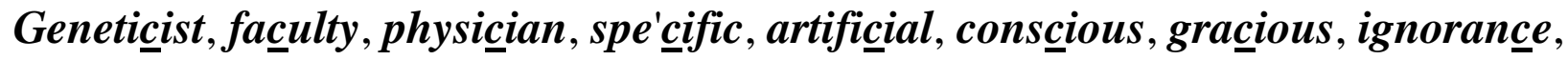

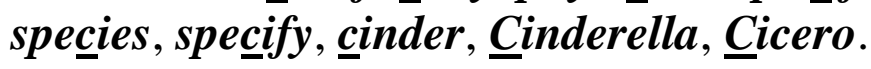

Ex. IV. State the proper reading of " $g$ " $\mid g]$ or $\left[d_{3}\right]$

Great, gymnasium, geologist, 'origin, 'genes, ago, 'pigeon, huge, change, piggy.

$E x . V$. Read the following pair of words. Mind the reading of " $x$ ".

\begin{tabular}{|c|c|c|c|c|}
\hline ex'hibit & e'xecutive & e'xert & $e^{\prime x a m i n e}$ & 'expert \\
\hline 1 & 2 & 3 & 4 & 5 \\
\hline exhi'bition & 'execute & excuse & expe'dition & e'xample \\
\hline 'exercise & e'xcile & exit & 'xylophone & 'xylonite \\
\hline 6 & 7 & 8 & 9 & 10 \\
\hline$e^{\prime x a g e e r a t e}$ & $e^{\prime} x u l t$ & $e^{\prime} x i s t$ & 'xerox & 'xylograph \\
\hline
\end{tabular}

Ex. VI. Underline the words in which the given sound is pronounced.

$[\Theta]$ they, though, thought, than, thank, then, thence, them, theme, there, that, these, those [k] chain, chlorine, chemical, cheque, chin, Christ, Christmas, chequer, technique [h] wheel, when, whole, whoop, white, whale, what, whence, where, whetstone, whey, whip, whirl, whisper

\section{Ex. VII. Read the following.}

but-bat-bate, cut-cat-cate, lump-lamp-lame, butter-batter-better, luster-latter-letter, bank-bunk-bent, pudency-pure-purr, cupid-cure-cur, car-care-current, per-peri-perfect, stir-stereo-swirl, bath-bathe-butter, lark-luck-lake, sandwich-send-sunny

\section{Grammar Exercises}

\section{Ex. I. Use the proper form of "to be". Translate the sentences into Russian.}

1. I (to be) a first-year student of the same faculty. 2. Her sister (to be) a part-time student. 3. They (to be) interested in the History of Russia. 4. My aunt and uncle (to be) physicians. They (to be) off duty today. 5. Their daughter (to be) my cousin. 6. My elder brother (to be) not a student. He (to be) a physicist. His daughter (to be) my niece. 7. My sister (to be) an engineer. Her two sons (to be) my nephews. 8. We (to be) fond of arts subjects. 9. Our students (to be) on duty today.

\section{Ex. II. Insert suitable personal and possessive pronouns.}

1. The girl is from Russia. is Russian.

language is Russian. 2. Those engineers are from Japan. are Japanese. language is Japanese. 3 . The driver is

from France. Canada. is French. Germany. are Canadians. are Germans. language is French. 4. My sister and I are from language is English. 5. The scientists are from language is German. 6. The artist is from Spain. is a Spaniard. language 
Italians. language is Italian. 8. You are technicians from Turkey. are Turks. language is Turkish. 9. This young man is from Greece. is Greek. language is Greek. 10. Those young men are from Latin America. are Peruvians, Brazilians and Bolivians languages are Spanish and Portuguese.

Ex. III. Translate into English. Define the function of "to be" (notional, auxiliary, modal, link-verb).

1. Это университет. 2. В университете тринадцать факультетов 3. Эти юноши и девушки студенты-гуманитарии. 4. Они должны будут изучать гуманитарные предметы. 5.История, языки называются гуманитарными предметами. 6. Эта девушка студентка факультета иностранных языков. Она любит читать книги зарубежных писателей. 7.Это моя кузина. Она очаровательна. Она замужем. Её муж инженер.

Ex. IV. Use proper pronouns instead of those in brackets.

1. (Их) child is five. 2. (ОН) is fond of helping (своей) mother 3.(Ваши) students are in the library and (наши) are in the laboratory. 4. I know (его) and (его) sister well. 5. This is (твой) dictionary and that is (её) 6. This is not (мой) dictionary, (мой) is in (моей) bag. 7. This is (наш) University. 8. This is (их) hostel. 9. (Она) wants to read (свой) translation and (они) want (свои). 10. Salt is a very important mineral in (нашей) every day life. 11. (Их) stories are very interesting. Read (их).

Ex. V. Answer the questions using possessive pronouns.

1. Whose book is this? It's [моя]. 2. Whose book is that? That's [ваша]. 3. Whose books are these? They are [наши]. 4. Whose lectures are those? They are [их]. 5. Whose newspapers are those? They are [её]. 6. Whose computer is this? It's [мой].

\section{Oral Speech Practice}

Make up dialogues on the model.

a) I like the girl (woman, boy, their cousin). I think she (he, they) is (are) pretty, and sincere, (hard working, attractive, charming, industrious, clever).

b) Yes, I like her (hint, them) too. I think she is very nice and good-looking (handsome, diligent, intelligent).

No, I don't like her (him, them). She (he, they) is [are] selfish, lazy, dishonest, snob. 


\section{Lesson II}

Phonetics: Possible ways of reading " $a$ " and letter combinations with it, sentence

Grammar: Wordbuilding; wordorder; thegeneralquestion

[ei] [a:] [०:] [عə]

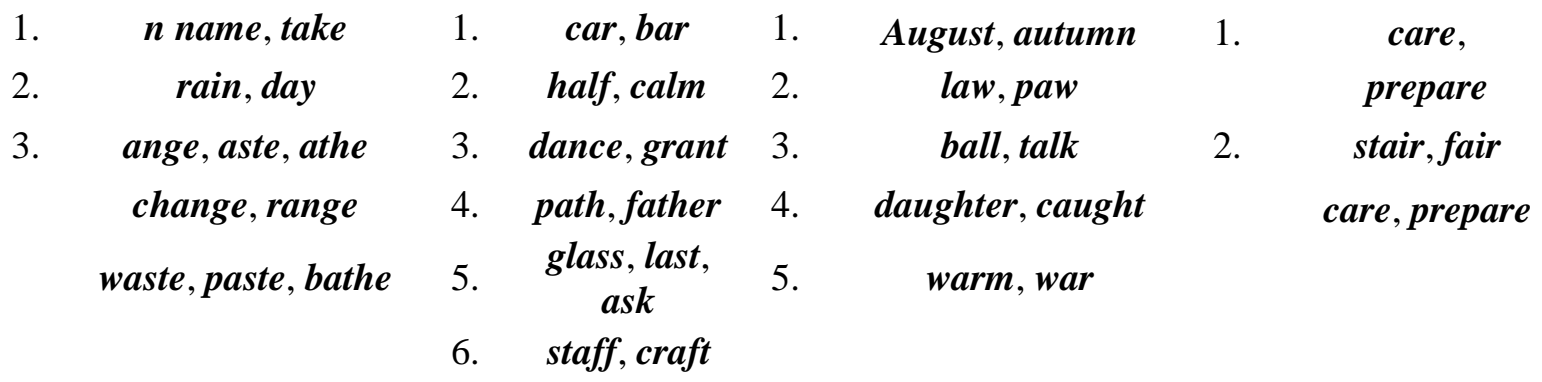

[०:]

[ǽ]

[i:]

1. want, wash wander

$\begin{array}{ll}\text { 1. } & \text { cat, } \text { can } \\ \text { 2. } & \text { carry, } \text { carrot } \\ \text { 3. } & \text { karry - эвкалипт } \\ & \text { разноцветный }\end{array}$

1. Caesar

\section{Фразовое ударение}

- выделение голосом одних слов в предложении среди других неударных. Ударными в английском языке обычно бывают знаменательные слова (существительные, прилагательные, смысловые глаголы, числительные, наречия, указательные, вопросительные местоимения).

Неударны обычно служебные части речи (артикль, вспомогательный глагол, предлоги, личные и притяжательные местоимения, союзы).

Английские неударные слоги внутри смысловой группы (синтагмы) имеют тенденцию примыкать к предшествующему ударному слогу: только начальные неударные слоги всегда примыкают к последнему ударному слогу.

I take it you already know.

\section{Phonetic Exercises}

Ex. I. Group the words according to the reading of " $a$ ".

Chain, spare, various, declare, parent, share, Spain, rain, daily, play, stay, range, waste, frame, table, Australia, daughter, catch, caught, taught, want, wash, wasp, war, warn, wart, chalk, talk, chance, half, staff, stall, call, fall, law, stare, straw, chair, stair, carry, barrack, barracuda, barret, barrier, barrister, carrot, crawl, rang, past, paste.

Ex. II. Give quick and proper reading of the following word combinations.

Passenger planes, part and parcel, take care, take it for granted, a cat and a rat, sat on a mat, the man came late, war and peace, a car passed, are awarded grants, plants and Аутлева Ф.А., Читао Н.А., Хатхе А.А., Симбулетова Р.к. 
animals, the span of man's life, a quarter of a glass, languages and law, a penny saved, a penny gained, at any rate.

\section{Ex. III. Mark the stress, read the sentences and translate them.}

1. The card is in the hand. 2. Ann and Pat are architects. 3. Jane draws what she wants. 4. Add and Jane are afraid of the lake. 5. Her bag hangs on that hat-rack. 6. Магутаy take the train the same day. 7. The car is in the garage [gǽra:3]. 8. Father can't start the car. 9. Are they dancing in the garden? 10.He lay awake taking pains to save the state. 11. Ralf gave the lady some stale cakes.

\section{Словообразование}

1. Словосложение - соединение двух и более основ разных частей речи,

сущ. + сущ . - - airport, newspaper

прил. + сущ . $\quad$ - blackboard

сущ. + прич.II - man-made

Ударение в сложных словах ставится на первое слово.

2. Аффиксация - образование новых слов при помощи суффиксов и приставок или и того, и другого.

Суффиксы и приставки часто безударны.

cover-discover-discovery, science - scientific - scientist

3. Конверсия - образование новых слов без изменения графической формы слова и места ударения.

We live in a new house. Our library has a lot of different books.

4. Два существительных, стоящих рядом, могут выступать в роли определения и определяемого слова. Первое существительное является определением и переводится на русский язык прилагательным или существительным в родительном падеже.

Institute laboratory, management skills - навыки управления

\section{Основные приставки}

a-, ab-, be-, com-, con-, de-, dis-, ex-, il-. im-. in-, inter-, intra-, ir-, over-, per-, pro-, pre-, re-, sub-, un-, en-, for-, mis-, trans-, se-, ob-,en-

$\boldsymbol{a}$-, $\boldsymbol{a b}$ - наречно-предложные приставки: along, about, across, begin, belong, contribute, prepare, proclaim, enlarge

\section{Отрицательные приставки}

un-uninteresting, unimportant

in - indefinite, inert

il-illiterate, illegal, illogical

ir-irregular, irrational

im-impossible, impolite

dis-discovery, disagree, disappear 


\section{Grammar Exercises}

Ex. I. Read, translate the derivatives. State the type of wordbuilding.

Cover-discover-discovery, response-responsive - responsible, special-specialist -specialize, academy-academic-academician, science-scientific-scientist, newspaper, apple-tree, bluebell, dining-room, changing-room, boiling, temperature, shareholders.

Ex. II. Translate the sentences into Russian paying attention to the underlined words.

1. This is a very detailed plan. 2. We plan to finish our work next week. 3. Professor Ivanov lectures on that subject at our University. 4.1 like his lectures very much. 5. The terms in the University last for 17-19 weeks. 6. The last month of the year is December. 7. Water is a liquid. 8. Water your flowers. 9. Paper is white. 10. Paper your room. 11. Two heads are better than one. 12. A competent scientist heads this expedition.

Ex. III. Translate the given word combinations.

Oil export, export oil, mass production, production achievements, air pressure, World Peace Congress, study films, a picture gallery, water-colour painting, flexible work hours program, data processing, management skills.

Ex. IV. Read, translate the sentences. Define the function of "to be".

1. Her niece is a first-year student. 2. Each student is to write papers on the subjects he is interested in. 3. We are interested in equipment for data processing. 4. The books of my nephew are on that shelf. 5. The academic year is divided into two terms.

Ex. V. Give short and full answers to the following questions.

1. Do you study at the University? 2. Are you a first-year student? 3. Is your family large? 4. Does his niece live at the hostel? 5. Does her nephew study at the Technological Institute? 6. Does she speak English well? 7. Do they know German well? 8. Does your mother work? 9. Is your father development engineer [разработчик] of this equipment? 10. Are you to translate the text by tomorrow? 11. Is this book translated into Russian? 12. Are you fond of reading? 13. Is your mother fond of watching TV?

Ex. VI. Translate into English.

1. Твоя мама врач? 3.Она работает в больнице? 3.Твои бабушка и дедушка пенсионеры? 4. Ты интересуешься медициной? 5. Ты любишь читать? 6. Твои родители любят смотреть телевизор по вечерам? 7. Ты первокурсник? 8. Твоя племянница студентка технологического института? 9. Ты говоришь по-английски? 10. А твоя тетя говорит по-английски? 11. Нет, она не говорит по-английски. Она говорит по-испански. 


\section{Oral Speech Practice}

Make up dialogues on the model.

Do you like ice-cream (chocolates, spaghetti, football, chess, pop music, classical music)

Yes,...........

I do, I do very much

I like it very much indeed.
No,

I don't, I don't like it at all.

I can't say I do.

Are you fond of reading (travelling swimming)?

Are you interested in...

$$
\begin{gathered}
\text { Yes,........... } \\
\text { I am. }
\end{gathered}
$$

I am very much indeed
No,

I am not.

I am not in the least.

Not very much. 


\section{Lesson III}

Phonetics: Possible ways of reading " $E$ " and letter combinations with it.

Grammar: Noun suffixes. Types of questions.

[i:]

1. he, Peter

2. season, tea

3. meeting, green

4. receive, seize, key

5. people

[iं]

1. here, mere

2. hear, near, beard

3. cheer, deer, steer

[u:]

1. grew, threw crew, drew, brew [e]

1. ten, pen

2. head, bread

3. measure, pleasure, treasure

4. breath, weather

5. in words heavens, leaven

[ei]

1. weigh, eight

2. reindeer,seine

3. skein, reign

[ai]

1. eye, neither seismic
[ว:]

1. her

2. learn, earth heard, pearl, dearth

[ju:]

1. new, few, dew deuce, feudal

[عə]

1. pear, bear, to tear

\section{Noun Suffixes}

$$
\begin{array}{ll}
\text { or }(\text { er }) & \text {-doctor, navigator, writer, reader, employer } \\
\text { ent }(\text { ant }) & - \text { student, assistant } \\
\text { ist } & - \text { communist, geneticist, physicist, geologist } \\
\text { ian } & - \text { musician, physician, technician, librarian } \\
\text { ee } & - \text { employee, refugee, referee }
\end{array}
$$

\begin{tabular}{|c|c|}
\hline tion. ssion [ $[\mathrm{n}]$ & -dictation, permission \\
\hline $\operatorname{sion}[3 n]$ & -profusion, division \\
\hline 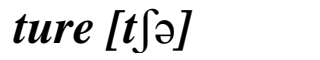 & - nature, creature \\
\hline 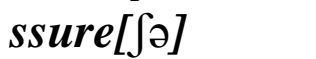 & - pressure \\
\hline sure [ 3ə] & - measure, pleasure \\
\hline ence $($ ance $)$ & - existence, performance, importance \\
\hline ment & - government, unemployment, merriment \\
\hline th & - growth, long-length, strong-strength, death \\
\hline ness & - business, sickness, lioness, laundress \\
\hline$y, t y, r y$ & - policy, family, activity, beauty, country, society \\
\hline
\end{tabular}

\section{Abstract Nouns}




\section{Phonetic Exercises}

Ex. I. Write the words in columns according to the reading of " $E$ " and letter combinations with it.

Excellent, knew, few, eight, seiner, feed, new, cream, each, teach, sphere, measure, grew, brewer, head, threat, crew, dear, pleasure, mercury, term, ceil, receive, mere, leather, deceive, deceit, receipt, feather.

Ex. II. Choose the proper reading of the suffix.

a) $\left[\int n\right][3 n]$

Diversion, diffusion, division, mission, profusion, oppression, conclusion, suspension, invasion, vision, permission

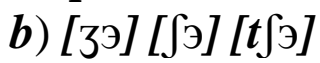

Pressure, pleasure, adventure, treasure, creature, nature, departure, measure, leisure.

Ex. III. Give quick and proper reading of the following word combinations. Write them in transcription.

1. Freedom and peace. 2. Bees on the trees. 3. To be or not to be. 4. East or west. 5. And the melody of bells. 6. Some merriment foretells.

Ex. IV. Mark the stress, read the sentences and translate them into Russian.

1. The Gentian girl learns her work. 2. She heard her sing. 3. The early bird catches the worm. 4. Ten hens went over the fence. 5. Henry said he served in the navy.

\section{Grammar Exercises}

Ex. I. Form nouns from the given adjectives, use suffix "th"

Strong, deep, long, wide, broad, high.

Ex. II. Change the following words into nouns denoting profession.

Geography, lecture, found, employ, study, account, assist, science, Genetics, Physics, library, music, physic, refuge.

Ex. III. Give English equivalents.

Геолог, химик, физик, генетик, техник, библиотекарь, врач, музыкант, математик, служащий, помощник, бухгалтер.

Ex. IV. Ask general questions and questions to the subject.

1. My sister speaks English. 2. My cousin studies at the University. 3. Her niece is a first-year student. 4. Our students work much in the library. 5. Every month all the students get grants. 6. The books of my nephew are on that shelf. 7 The University consists of 13 faculties. 8. The academic year is divided into two terms. 9. Bright students are awarded scholarship every month. 
Ex. V. Ask all types of questions to the following sentences.

1. The University trains specialists for various branches of economy. 2. The academic year in the University starts in September. 3. Non-Maikop students live at the three hostels of the University. 4. Bright students are awarded scholarship. 5. My elder brother is a full-time student of the University.

\section{Ex. VI. Answer the following questions.}

1. Are they on holiday or on business? 2. Is he one of the shareholders of this jointstock company? 3. His uncle is a forwarder, isn't he? 4. What are they, if they work at a hospital? 5. What does a builder do? 6. Who studies Genetics? 7. Where does the librarian work? 8. Where does an employee work? 9. Does it take you much time to translate an article into Russian? 10. How much time does it take you to translate an article into Russian?

\section{Oral Speech Practice}

Make up dialogues on the model.

I think that 1. travelling is always pleasant.

2. health is the most important thing.

3. Chemistry is not so difficult as Physics.

4. to study the art of healing is difficult. Yes,...

$$
\text { No,... }
$$

I quite agree with you I don't think so It is. 1 think you are mistaken

I think so too Nonsense 


\section{Lesson IV}

Phonetics: Possible ways of reading "I,Y" and their letter combinations.

Grammar: Verb suffixes, modal verbs.

[ai]

1. dye, type, die

2. child, mild

3. kind, mind

4. climb, chimb

5. night, high

6. bridle, trifle, title,

sidle, stifle, nitrogen [ə:]

1. bird,

2. myrtle, shirt [i:]

1. piece, niece

2. relief, relieve

3. thieve, thief, mien,

[aiว]

1. tired, tyre, spire, spiral

[i]

1. myth, thistle, system, picnic

2. snivel, sliver, striven, given, driven

Phonetic Exercises

Ex. I. Group the words according to the reading of "I, Y".

Field, retriever, kind, bind, mind, night, benighted, flight, tights, sieve, shield, child, entitle, phylum, piracy, pirate, quire, siege, slice, sidle, slid, smirk, thigh, liver, swivel, thrive, thriven, xylograph, xylonite, stifle, bridle, idle, brief, niece, mirth, miry, nitrogen, flipper, slide.

Ex. II. Decipher the meaning of the transcribed words.

1. [ai] think the animal is blind in one [ai]. 2. I want to [bai] some books [bai] Byron. 3. I didn't [rait] I was [rait].

\section{Ex. III. Write in transcription.}

Time and tide wait for no man. 2. Birds of a leather flock together.3.The early bird catches the worm. 4. I am sick and tired of the whole thing. 5. Will you give me a lift to the airport? 6. There was a young lady of Niger. 7. Who went for a ride on a tiger. 8. They returned from the ride. 9. With the lady inside.10. And a smile on the face of the tiger.

\section{Verb Suffixes}

$$
\begin{array}{ll}
\text { ate } & \text { - demonstrate, eliminate } \\
\text { ify, } y & \text { - modify, simplify } \\
\text { ize } & \text { - central+ize, general+ize } \\
\text { en } & \text { - widen, blacken } \\
\text { prefix }- \text { en - danger - endanger, joy - enjoy }
\end{array}
$$




\section{Grammar Exercises}

Ex. I. Give derivative verbs from the following words, use given suffixes and prefixes. Translate the derivatives into Russian.

+ ate facility, active, dictation, population, demonstration

+ ize [ise] real, central, popular, liberal, minim, formal, anatomy, systematic

+ en black, wide, white, deaf, dead, tough, strength

en+ large, danger, able, chain, circle, close, code, joy, rich, trap, gender.

Ex. II. Translate the sentences into Russian, mind the meaning of modal verbs.

1. He can translate this text without a dictionary. 2. Can I leave a message for him? 3. Can he know English so well? 4. They can't be at home now. They are to work in the laboratory at this time. 5. I'm sorry. I'm late. May I come in? 6. May I use your phone? 7. Hello, Peter. Can you come to tea tomorrow? I'm sorry, Nick, but I can't manage it. I'm booked up every day this week. 8. Take your umbrella. It may rain. 9. You can't cross the street against the red light. 10. If you want to eat the fruit you must learn to climb the tree. 11. You must be very ill. You look so pale. 12. Where is Ann? Can she still be in the library? 13. No, I don't think she is in the library. She must be at home at this time. 14. He is so rich that he doesn't have to work. 15. They are to meet at the entrance to the theatre. 16 . When is she to leave for London? 17. Who is to take pan in the amateur performance? 18. You are to open a letter of credit with the Moscow Bank. 19. Do you often have to work in the library? 20. Yes, because I share the room with 4 students and I can't work in the room.

\section{Ex. III. Translate into English, paying attention to modal verbs.}

1. Он, возможно, приедет ночным поездом. 2. Можешь ли ты помочь мне с работой? 3.Вы должны приходить на занятие вовремя. 4. Ты можешь говорить поанглийски? 5. Ты можешь курить здесь. 6. Они не должны курить в детской. 7. Какую из этих книг я могу взять домой? Можешь взять любую, но ты должен вернуть её через неделю. 8. Здесь темно, я ничего не могу видеть. 9. Он, возможно, напишет тебе об этом сам. 10. Ты можешь прийти ко мне завтра? 11. Неужели он переводит тексты без словаря? 12. Ты, должно быть, живешь далеко, если тебе приходится ездить этим автобусом.

\section{Oral Speech Practice}

Ex. I. Practise asking and giving direction on the model.

a) Excuse me, how can I get to the centre of the city (airport, railway).

b) 1) Go straight ahead (till you come to the traffic lights, cross road, then turn left (right).

2) Take a number ......bus (and get off at).

Does this bus (trolleybus) go to? Yes, it does.

a) You are at the Railway station. You want to go to the main square (to the University, the nearest hospital).

b) You are at the University. You want to go to the local theatre (the nearest bank, hospital). 
Ex. II. A friend of yours asks you for advice.

He (she) doesn't know: where to go for his (her) vacation whether to take up medicine or law

He (she) doesn't like the place where he (she) lives (works)

He is short of time (money)

He (she) wants to buy a new car

Advise your friend (use modal verbs)

You must (mustn't) be very rich (ask smb to help)

You can't be short of cash

You can't be serious 


\section{Lesson V}

Phonetics: Possible ways of reading " $O$ " and its letter combinations.

Grammar: Plural of English Nouns. Possessive Case.

[ou]

1. go, foe, toe

2. old, fold, cold

3. boat, coat, poach

4. blow, grow, throw, crow, tow, stow

5. soul, shoulder,

6. coulter
1. not, hot

2. sorrel, sorry
[^]

1. come, some

2. one

3. colour

4. mother, other

5. love, glove, cover

6. enough, rough, slough, tough, trouble, couple, courage, country, double cousin, touch

\section{[5:]}

1. more, core, port

2. four, court, course

3. brought, bought

4. floor, door [ə:]

1.work, world [u:]

1. moon, soon, spoon, pool

2. shoe, canoe

3. group, soup, route, troupe, who, whom, whose

\section{[UP]}

1. tour, moor, poor spoor

2. could, should, would

1.boy. toy

2. coin, boil

3. foot, soot, good, wolf

[r.]

Croesus ['kri:sas], Phoenix ['fi:niks]

Oedipus ['i:dipəs]

\section{Phonetic Exercises}

Ex. I. Group the following words according to the reading of "o".

Country, coin, goat, enjoy, pour, poor, about, none, sore, throat, voice, coat, thought, moon, course, spoon, canoe, aloud, fool, how, down, brought, rough, stout, fought, enough, worm, worse, covet, wonder, tongue, moor, spoor, bought, sound, score, tourist, board, mount, fountain.

Ex. II. Decipher the transcribed words.

1. The [houl] morning the mouse was making its [houl]. 2. What is the [fEə] to the

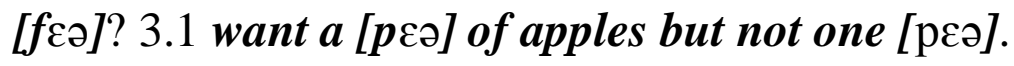


Ex. III. Read the plural of the following nouns.

Grants, studies, scholarships, branches, classes, laboratories, exercises, sentences, methods, houses, courses, cousins, uncles, societies, colleges.

IV. Mark the stress, read the sentences. Translate them into Russian. Mind the intonation.

1. Go home and show those roses to Joan. 2. Oh, no, I don't suppose so. 3. The normal span of man's life is threescore and ten. 4. Don't trouble trouble until trouble troubles you. 5. Whose books are over there on the counter? 6. The shoe is a bit tight across the toes. 7. The crowd shouted aloud outside. 8. How to count a thousand brown cows? 9. The noisy boy spoilt his voice. 10. Our townhouse costs about a thousand pounds. 11. You shouldn't look at the cookbook. 12. That book looks good. 13. She took one good look at the wolf.

\section{Grammar Exercises}

Ex. I. Give the plural form of the following nouns.

a) Price, society, laboratory, library, leaf, resource, bank, bench, stress, term, priority, stipend, grant, scholarship, child, man, tooth, mouse, house, solo, tomato

b) Millennium, datum, bacterium, curriculum, phenomenon, chela, formula, nucleus, stimulus, cirrus, analysis, bureau, portmanteau .

Ex. II. Give the singular form of the following nouns.

Men, women, sisters-in-law, statesmen, fishermen, geese, mice, passers-by, editorsin-chief, children, postmen, sons-in-law.

Ex. III. Change the following into plural.

a) 1. He is interested in the art of healing. 2. This family is large. 3. He is an engineer. 4. This device is new. 5. This child is my niece. 6. That man is my uncle. 7. This woman is a physician. 8. This path is wide. 9. That old man is my grandfather.

b) I have got an aunt. 2. She has got a daughter. 3. He has got a niece. 4 My hostel is far from the University. 5. The student is interested in a foreign language. 6. International trade is the job of the Merchant Bank.

Ex. IV. All in the family.

Your mother's mother is your grandmother. What do you call these people?

1. Your father's sister. 2. Your sister's daughter. 3. Your daughter's son. 4. Your son's wife. 5. Your wife's mother. 6. Your mother's father. 7. Your father's parents. 8. Your mother's grandparents. 9. Your mother's brother. 10. Your brother's son.

\section{Ex. V. Translate into Russian.}

1. I have got a new watch. It is very good. 2. My watch is fast. 3. This firm is engaged in the export of fruit. 4. Her hair is quite dark. 5. This news is very interesting. 6. Whom does this money belong to? 7. I don't know whom it belongs. 8. When does your summer vacation begin? 9. Our vacation begins on the 1st of July. 10. Your money is on the table. Take it. 
Ex. VI. Use the proper form of the verb.

1. Draughts

2. Physics

3. Scissorsa

4. Ill news

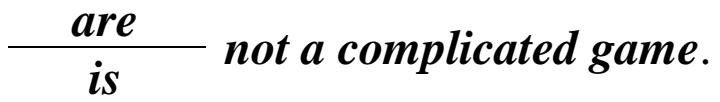

$\frac{\text { are }}{\text { is }}$ as difficult as Chemistry

are
is

$$
\frac{\text { travels }}{\text { travel }} \text { fast }
$$

5. All the available

datum show that the revolution started in the East

6. They became successful bussinesmen

\section{Ex. VII. Translate into English.}

1. Письмо нашего друга. 2. Дочь моей младшей сестры. 3. Младшая дочь моей сестры. 4. Новое общежитие студентов. 5. Условия (качество) жизни многих людей. 6. 90 \% льда и снега всего мира. 7. Дела компании. 8. Цели компании. 9. Успеваемость этого студента.

\section{Oral Speech Practice}

Tell someone that you:

can speak two foreign languages fluently, keep a lion as a pet, like taking medicine.

a) Let him (her) express incredulity:

1. No, I don't believe you; I can't believe you. You are not serious, you are joking.

2. Really? Come off it. You are pulling my leg.

Do you really?

b) Ask for permission to do something. Your friend either grants or refuses your permission.

May I (Can I)

Is it all right if 1

(switch on (off) TV, use your phone

ask you a question
(Yes) of course

No. I'm sorry you can't

No, That's all right

As you wish 


\section{Lesson VI}

Phonetics: Letter "U" and letter combinations with it.

Grammar: Numerals: Cardinal, Ordinal, Fractions.

[ju.]

1. tune, music, stupe, upas

2. ue - cue, due, hue

3. ui-nuisance, suit, tuque [tju:k]

[ə]

1. turn, burn

[juə]

1. cure, during

[u]

1.push, put, pull

bull, full

2. sugar
[^]

1. cup, bus, Sunday

2. current

3. judge, jump, ruff, rummage

[u:]

1.june, rule, true, truth, ruby, fruit, blue, rue, juice, jugate, juke, junior, ruminate

Phonetic Exercises

Ex. I. Group the words into 7 columns according to the reading of " $U$ ".

Blue, rut, rude, rue, ruler, murmur, purpose, upper, suit, sue, cure, pure, jury, sure, push, blush, bush, pussy, full, bull, rural, current, justify, run, rune, ruse, runic, rush, rummage, ruminate.

Ex. II. Decipher the transcribed words.

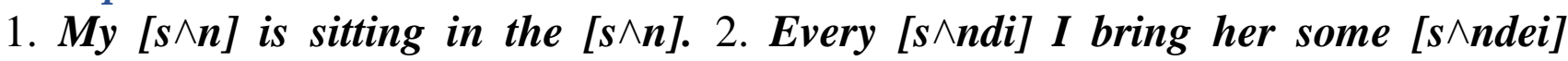
(сливочное мороженое). 3. There are [nou] new words in this text. I [nou] them all.

Ex. III. Mark the stress, read the sentences, translate them into Russian.

1. As snug as a bug in a rug. 2. Are you sure you can endure the curious smell of pure manner. 3. I'm sure the poor man was furious.

\section{Grammar Exercises}

Ex. I. Write in words:

а) $3,13,30 ; 5,15,50 ; 4,14,40 ; 0.36 ; 2,452 ; 2.452 ; 21 \% ; 9-04-44 ; 4^{\circ}$ C; $1 / 2$ км; 2/3 дюйма, $22 / 3$ км.

b) ordinal numerals 3,9,12,425,362,101. 
Ex. II. Write the following numerals in figures.

1. seventy-five thousand one hundred and thirty-seven. 2. four hundred and twentyfive thousand seven hundred and five. 3. the four hundred and fifty-sixth. 4. one million three hundred and six thousand five hundred and twenty. 5. ten sixth. 6. it is a quarter to four. 7. in ten minutes. 8. Ten minutes later. 9. contract four-to-five. 10. room seven-twofive.

\section{Ex. III. Translate the following sentences paying attention to numerals.}

1. The Atlantic is 2-й only to the Pacific among the world's oceans and covers about 1 '5 of the earth's surface. 2. Ocean levels continue to rise at 2'5 of an inch per decade. 3. The exercise on page 3 is very difficult. 4.1 take size 35 in shoes. 5. In 1906 San Francisco experienced an earthquake. 6. The fires following the earthquake raged for 3 days and destroyed 4'5 of the city. 7. Manchester is the largest port in Great Britain although it is 56 $\mathrm{km}$. away from the sea. 8. Covent Garden, the Britain's biggest market-place was officially established by King Charles II in 1670. 9. The Romans invaded Britain in 55 B.C. 10. The Roman armies left Britain in 410 A.D.

\section{Oral Speech Practice}

Dialogue on the telephone.

1. What a lucky chance! I have a message for you. Peter can't get at you, each time he rings you are out. You had better call him back.

2. 1 don't seem to remember his number. My memory for telephone numbers is no good, you know.

1. We can look it up in the (telephone) directory (telephone book). What section does it come under, I wonder?

2. It must be under "office numbers".

1. It's 23047 , extension 47

2. Hello, operator... Extension 47, please. What? Engaged? It's always that way when I have to get connected with Peter. The line is always kept busy. Either the switch-board or the extension number is engaged or Peter is not available.

1. Why not have another try?

2. Operator, Extension 47, please.

Operator. Hold the wire, please. Now, go ahead.

2. Is that you Peter?

Peter. Is anything important?

Operator. Sorry to interrupt you. There is an urgent trunk-call. Ring (call) up again in about 5 minutes. 


\section{Lesson VII}

Phonetics: English consonants having several ways of spelling, silent consonants.

Grammar: Indefinite Tenses.

[k] - k, c.cc.ch,ck.que: cake, accompany, quick, chemistry, technique

[d3] - g before e, i,y danger, large, singe, j-jar, jet, banjo.

[t]] -ch, tch chair, watch, speech, ture: nature, literature, s-tion question, combustion.

[J] - sh shape, share; tion - station, dictation: ssure - pressure, ch-in French words like machine, chandelier; ssion-mission, c+ian, ious, ient-musician, curious, gracious, ancient and in some words like Asia, Ocean

[3] - sure measure, pleasure; s+ion-division, profusion

[†] - n+g, [k], nc, nx, nqu, nch-anchor, lynx, conquer, kingfisher

[j] $-y+a$ vowel $-y e s$, yesterday, yellow

\section{Silent Consonants}

B- when final and preceded by -m-

climb, bomb, lamb, thumb

in a few words before - $t$ - debt, doubt, subtle

$C$ - ascend, muscle, scene

G - before -n-

gnu, gnome, gnat, gneiss

- before final $-n,-m$

reign, sign, paradigm, diaphragm

- after $-i$, ou, au, + gh

light, bright, brought, daughter

$\mathrm{H}$ - initial -gh-ghetto, ghost

- initial -th-

- Thomas, Thames,

- rh- rhetorics, rhythm

- xh-exhaust, exhibit

in words of French origin - hour, honour, heirdom

K- initial before $-n$ -

knife, knight, knowledge

L - when followed by -m- qualm [kwa:m], psalm [sa:m], balm [ba:m]

$-f$ - (ve) - calf, half, salve

-k-talk, walk, folk and in -could, would, should

$N$ - final after - $m$ -

autumn, column, solemn

$P$ - initial -pn-pneumonia, pneumatic

-ps- psychology, psychologist

-pt-ptarmigan, ptisan, ptomaine 
$S$ - island, isle

$T$ - listen, castle, fasten

$W$ - initial - before -r-write, wrong, wrist

- wh + o-whom, whose

- answer, sword

\section{Phonetic Exercises}

Ex. I. Spell, trancribe and read the following words.

Psychology, pneumatic, where, while, why, honour, ptarmigan, heir hour, honest, Thomas, rhinoceros, rhubarb, rheumatic, exhaust, ghetto, exhibit castle, listen, island, isle limb, thumb, doubt, debt, gnome, gnostic, reign, ring, sing, brought, fought, bought, taught, daughter, wrist, wrong, write, answer, balm, calm, palm, half, chalk, talk, walk, qualm, salve, science, scene, knife, knight, knowledge, whistle, school, schooner, scheme, autumn, solemn, column, folk, yolk, tuque, technique, physique, feign, rhomb.

Ex. II. Some of the following words are spelt in a similar way, some are pronounced in a similar way. Which words rhyme with each other?

Bough, rough, plough, tough, through, though, enough, so, grow, cow, how, sew, owe, grew.

Ex. III. Be sure to read these verses properly. They demonstrate that in English pronunciation there are more exceptions than rules. Write out irregular verbs, give their Past Indefinite forms.

I take it you already know

Of tough and bough and cough and dough

Others may stumble but not you

On hiccough, thorough, lough and though.

Well done! And now you wish, perhaps,

To learn of less familiar traps?

Beware of heard, a dreadful word,

That looks like beard and sounds like bird.

And dead, it's said like bed, not bead

For goodness' sake don't call it "deed"

Watch out for meat and great and threat

(They rhyme with suite, and straight and debt)

A moth is not a moth in mother

Nor both in bother, broth in brother,

And here is not a match for there

Nor dear and fear for bear and bare, Аутлева Ф.А., Читао И.А., Хатхе А.А., Симбулетова Р.к. 
And then there's dose and rose and lose -

Just look them up - and goose and choose,

And cork and work and card and ward

And font, and front and word and sword.

And do and go and thwart and cart -

Come, come, I've hardly made a start.

A dreadful language! Man alive,

We have to start when we're five.

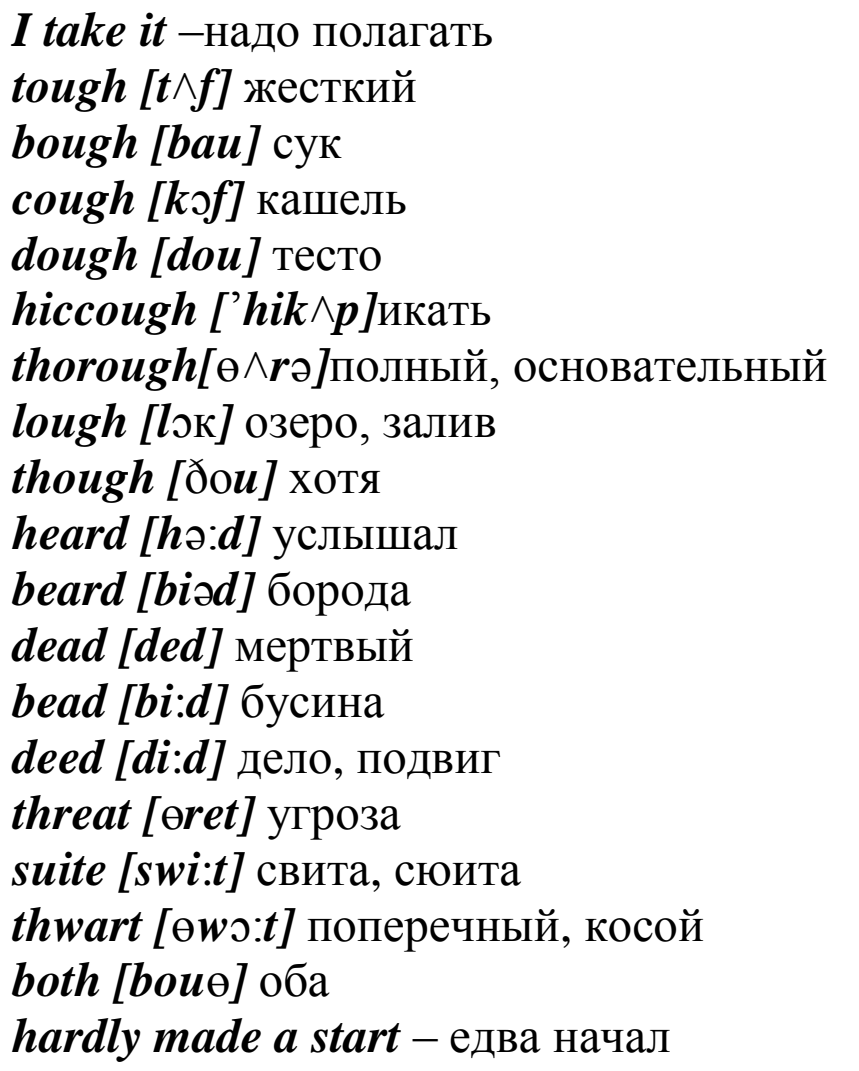

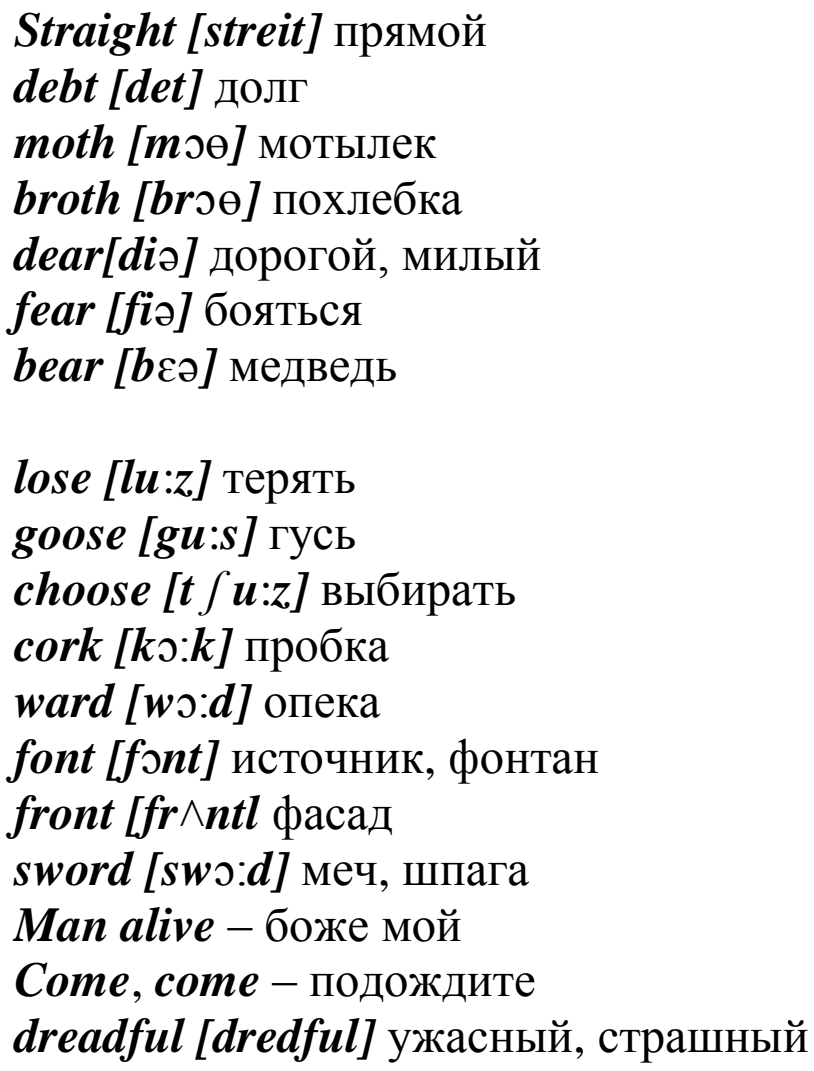

\section{Grammar Exercises}

Ex. I. Read the following verbs, adding "s"(3 rd person singular). Mind its reading.

To write, go, play, train, take, study, push, brush, fix, occupy, deny, do, make, share, cut, get, sing, sing.

Ex. II. Translate the adverbial modifiers of time, and the sentences.

a) 1. Peter was ill (вчера) so he stayed at home.

2. It was Sunday (позавчера).

3. [Вчера вечером] he came home late.

4. We translated this text (на прошлой неделе).

5. He returned from London (неделю назад).

6. They began to study English (3 месяца назад).

b) Use the above written sentences in the Future Indefinite, change the adverbial modifiers of time. 
Ex. III. Open the brackets. Translate the sentences into Russian.

1. Light [travel] more quickly than the sound. 2. He [laugh] best, who laughs last. 3. Every star [have) its own orbit. 4. Water [boil] at $100^{\circ} \mathrm{C}$.

Ex. IV. Give the Past Indefinite form of the following verbs,

a) Mind "ed" reading.

Connect, wish, permit, prefer, suffer, panic, picnic, study, occupy, comprise, discover, divide, call, compose, wash, inhabit, protect, answer, play, carve, cover.

b) Be, begin, buy, break, bring, build, catch, choose, do, drink, eat, know, leave, lie, lose, grow, forget, give, go. have.

Ex. V. Use the appropriate form of "to be".

1. I__ a physician. 2. We students of Natural Sciences faculty. 3. It Thursday yesterday. It Sunday in two days. 4. Only half a year ago the students.

Now they engineers. $5 . I$ on duty tomorrow. As for her she on duty same 2 or 3 days ago.

Ex. VI. Add question -tags to the following sentences.

1. Bernard Shaw was born in 1865.2. The first chemical laboratory in Russia was founded by Lomonosov. 3. My elder sister doesn't like to lend books. 4. You didn't go to the reference library yesterday. 5. Mendel's name is associated with Genetics.

Ex. VII. Ask questions to which the underlined words are the answers.

1. It took me an hour to translate the text without a dictionary. 2 . At half past 12 she stopped her work. 3. I share the room with three students. 4. Light travels more quickly than the sound. 5. My father-in-law works at a joint-stock company. 6. We are interested in equipment for data processing. 7. He often takes part in international seminars.8. They opened a Letter of Gredit with the Moscow Bank.

\section{Ex. VIII. Translate into English.}

1. Я учусь в университете. 3.Наш университет готовит разных специалистов. 3. Я студент первого курса. 4. Мой друг второкурсник, т.к. он поступил в университет в прошлом году. 5. Твой друг живёт далеко от университета? 6. Тебе много времени требуется, чтобы добраться до университета? 7. Кто твой двоюродный брат? 8.Он генетик. 9. 0н женат, не так ли? 10. Да, он женился полгода назад. 11. Они живут с родителями или снимают квартиру? 12.Кто родители твоего друга? 13.Они оба врачи. 14.Ты работал или учился в прошлом году? 15.Когда у тебя каникулы? 16.Где ты будешь через неделю? 17. Ты поедешь куда-нибудь? 18.Да, мы с сестрой ездили к бабушке в прошлом году. 19. И в этом году мы поедем туда же. 20. Мне нравится проводить каникулы у них. 21. Сколько времени вам требуется, чтобы добраться к ним? 22. У нас уходит два часа, чтобы попасть к ним. 23. Когда твой племянник пойдет в школу? 24. 0н уже школьник. 25. Он начал посещать школу в прошлом году. 26. Я думаю, я смогу помочь тебе. 27. Боюсь, что он не сможет вернуться вовремя. 28. Я рад, что смог помочь ему вчера. 29. Нам придется пойти туда завтра. 30. Тебе долго пришлось ждать его вчера? 
Ex. IX. Use Future Indefinite or Present Indefinite of the verbs in brackets.

1. I shall do it if it (to be) necessary. 2. I don't know when he (to finish) the book, but as soon as he (to finish) he (to give) it to me. 3. I (to wait) for you here till you (to come). 4. He (to translate) this article when he (to get) a good dictionary. 5. As soon as you (return) we (to begin) the work. 6. If the weather (to be) fine tomorrow, we (to go) to the park. 7. Before 1 (to go) home, I (to send) you a telegram. 8. If he (to ask for), they (to do) it. 9. If you (to repair) the equipment we (to finish) the work in time 10. He (be able) to translate the article as soon as he (to get) a dictionary 11 . I don't know if he (to send) me a telegram before coming home. 12. I am not sure if he (to be able) to translate this article without a dictionary.

Ex. X. Translate the following sentences into English.

1. Через два дня он уже был здоров. Лекарство, должно быть, помогло ему.

2. Через два дня он будет здоров, если не будет выходить на улицу.

3. Через год я уже был студентом университета.

4. Через год я закончу школу и поступлю в университет.

5. Через неделю я уезжаю в Москву.

6. Через неделю он мог уже читать английские слова.

\section{Oral Speech Practice}

Speak on your family. The questions will help you.

1. Where do you come from? 2. What family do you come of? 3. How many are you? 4. So, your family is large, isn't it (is not large, is it?). 5. How old is your father? 6. What does he look like? 7. Is he tall or small? 8. Is he handsome or not? 9. What is your father? 10. Is your mother younger than the father? 11. What is her name? 12. What is she interested in? 13. What is she fond of? 14. How old is your brother (sister)? 15. Is he a family man? 16. Have you aunts and uncles? 17. Has your sister a family of her own? 18. Do your brothers (sisters) have children? 19. What does your brother do for living? 20. How old are your niece and nephew? 21. Do your parents have their mother and father?

a) Make up a dialogue with your friend to learn about your families and relatives, use all types of questions.

b) Make up a dialogue with your friend about photos in your family album. The list of the following words will be of some help.

Her name is Helen, Lena for short

He goes by the name of

He is called after his father

We are distantly related

He is my senior (Junior) by a year

He (she) looks young for his age

They are al I teen-agers

handsome (man)

lovely, beautiful, nice-looking

She is always full of joy and happiness

(bright and good-tempered)
Ее имя Елена, а уменьшительно Лена его обычно зовут

его назвали в честь отца

мы дальние родственники

он старше (моложе) меня на год

он выглядит моложе своих лет

им всем нет еще 20

красивый (о мужчинах)

милая, красивая, миловидная

она всегда жизнерадостна

весела и добродушна 
to be married

to marry smb for love

first cousin

second cousin

He has a working knowledge of English He has a good command of the language быть замужем (женатым)

выйти замуж по любви

двоюродный (ная) брат (сестра)

троюродный (ная) брат (сестра)

он практически владеет языком

он хорошо владеет языком

\section{Revision Exercises}

\section{Ex. I. Translate into Russian.}

1. I think English is terribly easy. No, I don't agree. I think it's hard. 2. I think you had better work harder if you are to pass all your exams excellently. 3. Taке a number 1 bus and get off at the University. Go straight ahead till you come to the traffic lights then turn left. 4. Where does she come from? I can't help you (there). I don't know. 5. You will come, won't you? Sorry, I can't promise. I am booked up the whole day. 6. What time is it? I am not sure because my watch is fast. 7. What shall we have for supper? 8. Which you like better writing or receiving letters? I like receiving letters better. 9. When shall we leave for London?

\section{Ex. II. Translate into English using the active vocabulary of the introductory course}

1. Тебе нравится путешествовать? Не могу сказать, что очень нравится. 2. Могу я поговорить с Леной? Очень жаль, но её нет дома. 3. Мне кажется (think), что они прилежные и трудолюбивые студентки. Я так не думаю. Ты ошибаешься. 4. Он, должно быть, очень богат, если хочет купить ещё одну машину. 5. Когда ты должен принести мне словарь? 6. Как только ты приносишь словарь, я перевожу этот текст для тебя. 7. Боюсь, у меня плохая память на телефонные номера. Если я не запишу твой номер, я забуду его через минуту. 8. Перезвони своим родителям, когда придёшь домой. 9. Кажется, я забыл номер его телефона. 10. Каждый раз, когда я прихожу в библиотеку, там много людей. 11. Тебе бы лучше принять лекарство и лечь в постель. 12. Тебе бы лучше записать его адрес. 13. Я не могу перевести это предложение, мне нужно (мне придётся) посмотреть несколько слов в словаре. 14. Каждый раз, когда мне нужно связаться с моим кузеном, его нет на месте или линия занята. 15. У меня новые часы. Они очень красивые. 16.Можно мне посмотреть их? Да, они на столе. 17. Когда начинаются твои каникулы? 18. Чьи это деньги? Это деньги твоей подруги. Она не захотела их забрать. 19. Я тоже думаю, что путешествовать очень интересно.

Ex. Ill. Read the following pair of words. Mind the difference in their reading depending on the part of speech.

- отстаивать, поддерживать

\section{1 advocate}

- защитник, сторонник

- делегировать

\section{2 delegate}

- делегат

- отделять 


\section{3 separate}

- отдельный

- близкий, приближённый

4 approximate

- приближать

- заканчивать учёбу (в университете)

5 graduate

- выпускник

- коллега, партнёр

6 associate

- ассоциироваться 


\section{ОСНОВНОЙ КУРС}

\section{Lesson 1. The University}

Grammar: Participles I, II. their functions in the sentence

Lexical commentary

$\begin{array}{lll}\text { Various } & - & \text { многообразный, различный } \\ \text { different } & - & \text { непохожий, отличный } \\ \text { learn } & - & \text { учиться чему-либо, учить наизусть } \\ \text { study } & - & \text { учиться в учебном заведении, изучать } \\ \text { teach } & - & \text { учить кого-либо, преподавать } \\ \text { tell } & - & \text { вводит косвенную речь, требует беспредложное дополнение } \\ \text { say } & - & \text { вводит и прямую и косвенную речь, требует предложное дополнение } \\ \text { speak } & - & \text { говорить на языке (с кем-либо, о чём-либо) } \\ \text { talk } & - & \text { непринуждённая лёгкая беседа, болтать } \\ \text { talks } & - & \text { переговоры } \\ \text { live } & - & \text { долго, постоянно жить } \\ \text { stay } & - & \text { остановиться, временно } \\ \text { share } & - & \text { жить в одной комнате скем-либо } \\ \text { grants } & - & \text { стипендия } \\ \text { stipend } & \text { стипендия семинариста } \\ \text { scholarship- повышенная стипендия } \\ \text { yet } & - & \text { ещё не (в конце отрицательного предложения) } \\ \text { still } & - & \text { всё ещё } \\ \text { else } & - & \text { ещё в добавок } \\ \text { where else, } & \text { who else - где ещё, кто ещё } \\ \text { more } & - & \text { ещё один, другой }\end{array}$

Pretext Exercises

Ex. I. Use the proper word from the given in brackets.

1. Our University has (different, various) faculties. 2. Bright students are awarded (grants, scholarship, stipend). 3. Our students study (various, different) subjects. 4. My friend and I (live, share, stay) at the hostel. 5. (Various, different) people have (various, different) interests. 6. Words of the English language come from (various, different) sources. 7. I (stayed, lived, shared) there for three months. 8. I saw them during my (stay, life, sharing) in London. 9. Plant cells have (different, various) structure than animal ones. 10. (different, various) customers respond differently to a new product on the market. 11. To calculate the age of our planet one must have much knowledge in (different, various) branches of science. 


\section{Ex. II. Translate into English.}

1. Что ещё ты написал ему вчера? 2. Где ещё я могу достать эту книгу? 3. Кто ещё знает слова этой песни? 4. О ком ещё вы говорили вчера? 5. Кто ещё вступил в научное общество? 6. Мой товарищ ещё не женат. 7. Я ещё не закончила работу. 8. Твоя жена ещё студентка? 9. Твой племянник ещё интересуется иностранным языком? 10. Чем ещё интересуются ваши студенты? II. Где ещё вы видели его вчера? 12. Куда ещё вы поедете в отпуск?13. Почему вы ещё здесь? 14. Твоя тётя ещё болеет? Нет, ей уже лучше. Дня через два она выйдет на работу. 15. Дай мне ещё два яблока 16. Скажи эго ещё раз. 17. Вот ещё одна книга по этой теме.

\section{Ex. III. Insert the proper verb "говорить".}

1. Can you_any foreign language? 2. What language do you___with the engineers of this joint-stock company? 3. Have you begun the переговоры? 4.Have you heard the weather forecast? They_the weather will change for the better. 5. He__her: "Don't be late!" 6. Listen to me when I am_ ing to you. 7. Shhh! I can't hear what he is_ing. 8. When you see John, can you 9. He _ _so quickly that I can't understand him. 10. I'll him to come to my place. see him.

Ex. IV. Make up sentences using only the given words.

1. Of, learning, studies, higher, he, establishment, some, at. 2. Of, 13, branches, the, train, of, for, faculties, University, various, economy, specialists. 3. Starts, two, is, September, the, which, year, terms, divided, academic, in, into. 4. Am, Maikop, as, at, live, I, hostel, native, don't, I, a, of, the. 5. Month, paid, grants, every, students, are. 6. Developed, Institute, is, our, highly, in, social, life.

\section{The University}

The normal span of man's life is threescore and ten years. Almost a quarter of it he studies either at school or at any establishment of higher learning.

I study at the Adyghe State University. I want to tell you about my student life. I am a full-time student of the Natural Sciences faculty. Besides this faculty there are 12 more which train specialists for various branches of economy. The University has students of all kinds. It has its arts students, its medical students, its physicists. The students study arts subjects (History, languages, Economics or law), pure or applied sciences (medicine, Physics, Mathematic, Chemistry and so on).

The academic year in the University which starts in September is divided into two terms. Each term lasts for 18 or 19 weeks. The vacation between the terms is 2 weeks in winter, and two months in summer. The timetable generally goes from 9 a.m.to 4.p.m. with a break of about half an hour for lunch.

Every month students get grants, bright students i.e. students having high academic progress are awarded scholarship.

The University maintains three hostels. Therefore most non-Maikop students live at the hostel. As for me I don't live at the hostel, because I am a native of Maikop. I live a long 
way from the University that's why it takes me half an hour to get to the University by bus.

We work much in class, in University laboratories and in the library. Still in the first year some students join students scientific society. Each student is to write papers on the subjects he is interested in. It may' be Biology, Psychology, History and so on.

Social life is highly developed at our University. Students edit wall newspapers, take part in various amateur theatricals, sport competitions.

\section{Exercises to the text}

Ex. I. Give synonyms for the following words and the situations they are used in the text

Prepare, begin, apart from, 60 years, one fourth, twig, the art of healing, receive, holiday, participate, separate, one second, reach, must write, semester, aborigen, enter, office, stipend.

Ex. II. Give antonyms to the following words and the situations they are used in the text

A part-time student, finish, poor student, little, dirty, connect, professional, low, short, private life.

Ex. III. Use words from the text instead of the underlined ones.

1. Our University has three hostels. 2. As to me I don't live at the hostel. 3. My friend lives at the hostel which is not far from the University. 4. He lives with three students. 5. The students participate in amateur theatricals.

\section{Ex. IV. Translate into English using words from the text.}

1. Кто преподаёт у вас химию? 2. Где учится твой брат? 3. Он студент дневного отделения. 4. Имеет ли ваш институт общежитие? 5. В какое общество вступают студенты ещё на первом курсе? 6. Что касается их, они интересуются историей. 7. Студенты, имеющие хорошие и отличные оценки, награждаются стипендией. 8. Когда у неё каникулы? 9. Где ты обычно проводишь свои каникулы? 10.Это зависит от того, какие каникулы. 11. Зимние каникулы я всегда провожу у своей подруги на Севере. 12. А где ты проводишь свои летние каникулы? 13.Что касается летних каникул, которые длятся два месяца, я провожу их у своих родственников, живущих на море. 14. Ты должен писать работу по биологии в этом семестре? 15. Да, я буду писать работу и по биологии, и по психологии, если преподаватель даст мне темы. 16. Сколько студентов в вашей группе получают повышенную стипендию? 17.Где ты участвуешь, (в каких общественных мероприятиях института)? 18.Тебе часто приходится работать в библиотеке? Да, потому что нас в комнате 5 человек. Я не могу работать там. 
Ex. I. Give Pr. and Past Participle forms of the following verbs.

Study, begin, suffer, refer, buy, type, sing, die, dye, agree, transfer, picnic, label, panic, age, write.

Ex. II. Combine the given verbs in the form of Present or Past Participle with the proper noun.

E.g. Student, letter-to write

the written letter, the writing student.

Book, student - to write; letter, secretary - to type; problem, scientist - to study; document, manager - to sign; sun, hen - to singe; girl, song - to sing.

Ex. III. Translate into English paying attention to Participles/ I, II/ used as attributes.

1. Студент, изучающий эту проблему, много работает в библиотеке. 2. Проблема, изучаемая этим студентом, очень важна. 3. Мы всегда рады видеть человека, приносящего хорошие новости. 4. Книги, прочитанные в детстве, кажутся старыми друзьями. 5. Рассказы, опубликованные в этом журнале, очень интересные. 6. Листья, лежавшие на земле, напоминали об осени. 7. Америка - континент, открытый Христофором Колумбом. 8. Люди, преподающие в университете, должны знать основы психологии. 9. Студенты, имеющие хорошие и отличные оценки, получают повышенную стипендию. 10. Междугородние переговоры, которые заказал мой дядя, были с Лондоном. $11 . \quad$ Обед, приготовленный моей сестрой, был очень вкусный. 12. Роман, написанный этим писателем, был о студенческой жизни.

Ex. IV. Use Pr or Past Participle of the verbs in brackets.

1. The question /to discuss/at the last meeting is of great importance. 2. Shareholders Ito invite/ to the annual meeting came on time. 3. The book /to lose/ yesterday is found. 4. The fairy-tale /to read/ by our teacher was very interesting. 5. The man often /to see/ in our library came to ask for a new book. 6. Last year I read this book/to translate/ into Russian. 7. /To print/ books are beautifully illustrated. 8. The device /to invent/ by this engineer is of great importance. 9. Salt is one of the most important minerals /to use/ in our everyday life. 10. /To be/ a good engineer he was able to finish his work in a short time. 11. /To conduct/ the experiment they discovered an interesting phenomenon. 12. The experiment /to conduct/ yesterday will help us in our work.

Ex. V. Read, translate the following sentences, state the tense, aspect form of the predicate.

1. Are you still reading the book? Yes, I am. I have not finished it yet. 2. Are you doing your English? No, I have just done it. 3. Are you still making the experiment? No, I have just finished it. 4. Have you translated the text? No, I am still translating it. 5. Has she written the exercise? No, she is still writing it. 
Ex. VI. Use the verbs in brackets in the form of Pr. Participle as an adverbial modifier.

1. To know/ the rule very well, he could translate all the sentences. 2. /To change/ into ice, water becomes solid. 3. /To be tired/, I decided to stay at home. 4. /To have/ a lot of time, he walked to the Institute. 5. While /cross/ the street, he saw his old friend. 6. While /to read/ the book, she fell asleep. 7. /To be very tired/, I refused to go for a walk. 8. /To be/ very absent-minded, he made some mistakes in the dictation. 9. /To live/ far from the University, he has to take a bus and a trolley-bus to get there. 10. When /to comb/hair, I use a brush or a comb.

Ex. VII. Change the given sentences according to the model.

Model: Mary is waiting for her friend. The girl waiting for her friend is Mary.

1. My uncle is reading a magazine. 2. Tom and Ann are playing tennis. 3. John is translating an article. 4. Andy and Dick are lying in the sun. 5. Ann and Liz are swimming in the sea.

\section{Ex. VIII. Translate into Russian. Define the function of the Participle.}

1. Barking dogs seldom bite. 2. Not knowing his address, I could not send him a telegram. 3. A group of islands lying off the north-west coast of Europe is I/3D of its size. 4. The largest island of the group consisting of some 5 thousand islands is Great Britain. 5. Scotland having 186 inhabited islands is divided into 33administrative counties. 9. Reading much he enriches his knowledge. 7. While leading, he sees nothing around. 8. Why are you thinking of starting a business? 9. When selecting a trade name, pick up a short easy-to-remember name. 10. The decision made by this a ant-stock company effected company's affairs. 11. The defeated army fled into the hills. 12. Utterly exhausted, they fell asleep at once. 13. I will gladly come, when (whenever) invited. 14. A fault confessed is half redressed. 15. Lost time is never found again. 16. Liquids take the shape of the vessel containing them. 17. When translated, the instruction became perfectly understood. 18. If frozen, water becomes ice. 19. Hydrogen has many advantages as a fuel. When burned, it regenerates water.

\section{Ex. IX. Change the sentences according to the model.}

He has written a letter. This is the letter written by him.

1. He has lost a letter. 2. He has typed a letter. 3. He has registered a letter. 4. He has delivered a letter. 5. He has stamped a letter. 6. He has answered a letter. 7. They have bought a book. 8. We have bought a car. 9. She has translated an article. 10.1 have written the exercise.

\section{Ex. X Translate into English paying attention to Participles, mind their tense and aspect} forms.

1. Так как он был хорошим инженером, он быстро исправил прибор. 2. Пригласив друга в кино, он купил билеты в кино. 3. Приглашая товарища в кино, мы обычно говорим: "Пойдём в кино". 4. Играя главную роль первый раз, актриса волновалась. 5. Сыграв главную роль впервые, актриса имела успех. 6. Забыв его адрес, я не смог написать ему письмо. 7. Так как я оставил тетрадь дома, я не смог записать лекцию. 8. Так как я хотел пить, я купил газированной воды. 9. Придя на почту, я отправил 
заказное письмо. 10. Будучи прилежной студенткой, она получает повышенную стипендию. 11. Потеряв ключ, я не смог попасть в комнату.

\section{Ex. XI. Translate into Russian paying attention to the Participle.}

1. My job is interesting. I am not interested in my work anymore. 2. I'm always tired when I finish work. My job is tiring. 3. It was quite surprising that he passed the examination. Everybody was surprised that he passed the examination. 4. Did you meet anyone interesting at the party? Are you interested in buying a car? I'm trying to sell one. 5. The film was disappointing. I expected it to be much better. I was disappointed with the film. I expected it to be much better.

\section{Oral Speech Practice}

Ex. I. Answer the following questions and then speak on your University.

1. What establishments of higher learning are there in your town? 2. Which of them do you study at? 3. When did you enter the University? 4. How many faculties are there in the University? 5. Whom does your University train? 6. Аге you a full-time or a part-time student? 7. What year student are you? 8. Do you get grants or scholarship? 9. Do all students get scholarship? 10. What subjects do you study? 11. Do you study pure or applied sciences? 12. Do you study any foreign language? 13. When does the academic year start? 14. How often do you have your vacation? 15. Do you live far from the University? 16. How much time does it take you to get to the University? 17. Do you take part in the social life of the University? 18. What kind of activity are you fond of? 19. Do you go in for sports? Ex. II. Complete the dialogue.

A.

B. I'm interested in the system of higher education in your country.

A...

B. I'd like to visit a Technological Institute...

A...

A. It takes four or five years to obtain higher education.

B.The examinations the candidates take depend on the faculty they are to enter.

\section{Ex. U. Stage a dialogue between students of the University and the Technological} Institute, use the Russian text given below.

Отделение социально-культурного сервиса и туризма зародилось в рамках экологического факультета. А с 1 сентября 1996 года отделение выделилось в самостоятельный факультет социальных технологий, обеспечивающий три специализации: туристическое обслуживание населения, правовые услуги, музейный сервис. Курс обучения - $\mathbf{5}$ лет. Новый факультет предлагает своим студентам, помимо общеобразовательных, ряд предметов, редких в вузах страны. Например, валеология (умение вести здоровый образ жизни), основы искусствоведения, риторика, основы этики, эстетика, рекреационные ресурсы Адыгеи. Будущие работники туристического сервиса должны владеть двумя иностранными языками. После первого курса студенты проходят недельную практику в различных регионах Адыгеи и двухнедельную после второго курса, во время которой студенты планируют маршрут, оценивают и изучают Aymreва Ф.A., Читао К.A., Хамхе A.A., Симбулетова Р.К. 
район, учитывая природно-климатические особенности, намечают места стоянок. После третьего курса студенты проходят производственную практику в экскурсионном бюро на турбазах Адыгеи.

1. valeology

2. art criticlsim

3. rhetoric

4. advertising (for), publicity (to)

5. stopping, (halting) place

6. 6 curriculum

7. fundamentals of businessspeech -валеология

- искусствоведение

- риторика

- реклама

- стоянка

- учебный план, курс обучения

основы деловой речи 


\section{Lesson 2 A. Some Aspects of British Education}

Grammar: Passive Voice

\section{Pretext Exercises}

Ex. 1. Define the part of speech the following words belong to, translate the words.

Educate-education-educator-educational, compel-compulsory, acquaint-acquaintedacquaintance, comprehend-comprehension-comprehensive, provide-provision-provisional, practice-practical-practically, instruct-instructor-instruction-instructional, professprofessor-profession-professional, differ-different-difference, prepare-preparationpreparatory, follow-follower-following, supervise-supervisor-supervision.

\section{Ex. II. Translate the following word combinations into Russian:}

State school, state school children, metal work, wood-work, grammar school, grammar school pupils, education lecturer, college students, infant school, white-collar profession, school practice.

\section{Some Aspects of British Education}

Education in Britain is compulsory from 5 to 15 years of age. The first school is the Primary School, which comprises the Infant School for children between 5 and 7. At this stage children become acquainted with three $R$ 's ( $R$ 's - reading, writing, arithmetic) in the form of games. The next stage of the Primary School is the Junior School for children aged 7 to 11.

There are 3 main types of secondary schools: grammar, secondary modern and comprehensive schools. The comprehensive School provides all types of secondary education for all children in a district. Some $75 \%$ of all state school children go to the Secondary modem school. The general level of education in these schools is low, concentrating for the most part on practical work. Boys are instructed in metal work and wood-work, and the girls in domestic science and cooking. The Grammar School prepares pupils for universities. Grammar School children take two General Certificate of Education exams. They take the GCE (General Certificate of Education - свидетельство о среднем образовании) at ordinary (О-level), at the age of 16. Pupils may sit in 7 or 8 different subjects. After these exams most pupils leave school and follow some white-collar profession. A small number of pupils remain at school for another two years and sit for the GCE A-level, (advanced level). As it is a difficult exam pupils do not take it in more than 3 subjects. After these exams pupils can go to the University or a college, college of education, for example.

In colleges of education besides courses of lectures in general subjects they study the theory of education, teaching method and practice, Psychology and Hygiene. Every student must spend certain amount of time on school practice under the supervision of education lecturer. At the end of their three-year course the training college students get their professional qualification of Teacher's Certificate. Training college students teach in Infant and Junior Schools. 
Ex. I. Letter "a" can be read as [á]; [ei]; [a:]; [عa]; [o:]; [o] write out the words from the text to illustrate this.

Ex. II. Find English equivalents to the following.

Аттестат, общеобразовательные предметы, пединститут, педагогика, методика, профессия служащего, диплом учителя, начальная школа, средняя школа, педпрактика.

Ex III. Give antonyms to the following words.

High, easy, stay, at the beginning, optional, outdated, give

Ex. IV. Give synonyms for the following words.

Apprentice, apart from, chief, obligatory, common, nursery school, contain, region, up-to-date, quantity, guidance, a few, among, following.

Ex. V. Answer the following questions.

1. At what age do children in Britain begin going to school? 2. Which is the first school? 3. Into what stages is the Primary school in Britain, divided? 4. Children of what age attend the Junior School? 5. What do the Infant school children study? 5. What are the three types of secondary schools in Britain? 7. Which school provides all types of secondary education? 8. Which school do most children attend? 9. What are the girls instructed in at the Secondary Modem School? 10. Which school prepares pupils for universities? 11. How many GCE exams do Grammar School pupils take? 12. What subjects do training college students study? 13. Who supervises school practice? 14. How long do training college students study? 15. Where do college students work after finishing the college?

\section{Grammar Exercises}

Ex. I. Give Past Participles of the following verbs.

Be, teach, take, study, spend, spell, sell, tell, speak, write, give, call, pay, know.

Ex. II. Give:

a) Present Indefinite Passive of the verbs.

Write, speak, give, award.

b) Past Indefinite of Invite, call, divide,

c) Future Indefinite of

ask, change, laugh, pay. 
Ex. III. Translate the sentences into Russian, paying attention to the Passive form of the predicate.

1. The science studying living things is called Biology. 2. The first chemical laboratory in Russia was founded by Lomonosov. 3. Stained glass was produced in this laboratory. 4. The problem of photosynthesis is connected with the existence of life, 5 . The terms formula, thermometer, atmosphere were introduced into the Russian language. 6. The academic year in British Universities is divided into three terms. 7. Brightest students are awarded scholarship. 8. At the end of each month students are paid grants. 9. The letter was written in ink yesterday. 10. The doctor was sent for a minute ago. 11. The film is much spoken about. 12. I'll be glad if your article is published in this magazine. 13. Your article will be published as soon as you finish it. 14.1 think that he will be laughed at if he says ns. 15. Who will be invited to the party?

\section{Ex. IV. Make the following sentences passive.}

1. They often laugh at this boy. 2. Pupils study different subjects. 3. Pupils devote much of their time to play and drawing. 4. Lomonosov founded the first chemical laboratory in Russia. 5. I left the dictionaries on the table. 6. He referred to this article.

Ex. V. Express your satisfaction with the news according to the model.

Model: We decided to translate the text.

I'm glad the text will be translated.

1. He decided to use this material in his scientific work. 2. They decided to send him a telegram at once. 3. She decided to change the end of her story. 4. They made up their mind to discuss this question at the committee. 5. We made up our mind to finish the work in time. 6. I want to invite him to the party. 7. They decided to publish his article in the next month's magazine. 8.I decided to present my nephew with this book. 9. We shall take care of your son. 10. He will look for the documents.

Ex. VI. Answer the following questions. Use Passive constructions.

Model: Do you speak English in your English class?

Yes, English is spoken in our English class.

1. Did you discuss ecology problems at the conference yesterday? 2. Did Christopher Columbus discover America in the $15^{\text {th }}$ century? 3. Will they help us? 4. Will she see you to the station? 5. Will they translate the text? 6. Do they sell a lot of books every day? 7. Does your sister often write letters to her friends? 8. Did the engineer develop this new device? 9. Did you open a letter of credit with the Moscow Bank? 10. Will you invite him to the party?

\section{Ex. VII. Use the necessary Passive form of the verbs in brackets.}

1. Russia (to wash) by two oceans. 2. This student's article (to publish) in the magazine last month. 3. Next month's wall newspaper (to edit) by our group. 4. Scientific papers (to write) by brightest students. 5. The plural of English nouns (to form) by means of "s". 6. Paper (to make) from wood pulp. 7. Knives (to make) usually of steel. 
Ex. VIII. Translate from dictation the following and write down the translation, give back translation.

a) 1. This material can be used in your scientific work. 2. It must be done at once. 3. The letter can't be sent off today. 4. The lost key was found by my sister yesterday. 5. The work couldn't be finished in time. 6. The dictionary may be left on the table. 7. The end of your story must be changed. 8. This question must be discussed by the committee immediately.

b) 1. Неужели упражнение написано без ошибок? 2. Не может быть, чтобы такой текст, был переведён без словаря. 3. Возможно, ему помогают переводить такие тексты. 4. Письмо должно быть получено сегодня, раз оно отправлено два дня тому назад.

\section{Ex. IX. State the type of the predicate.}

1. The window is broken. 2. The window was broken by the storm yesterday. 3. The house was damaged by the fire. 4. The lost key was found. 5. The texts are translated, the dictionaries may be left on the table. 6 . The doctor has already been sent for.

\section{Ex. X. Translate into English.}

1. Я буду рад, если твою статью опубликуют в газете. 2. Я не знаю, будет ли опубликована твоя статья. 3. Когда работа будет закончена, я покажу её директору. 4. Я не хочу показывать тебе свою работу, пока она не закончена. 5. Он пойдёт туда с удовольствием, если его пригласят. 6.Я не знаю, пригласили ли его на вечеринку. 7. Я не знаю, пригласят ли его на вечеринку. 8. Письмо было отправлено два дня тому назад. Возможно, его получат сегодня. 9. Твою статью, возможно, опубликуют в журнале этого месяца. Ю.Эти документы должны быть отпечатаны сразу. 11. Когда будет опубликована эта статья? 12. Где будет опубликована эта статья? 13. Кем был спроектирован этот дом? 14. На чью информацию можно положиться? 15.Что производится на этой фабрике? 16. Когда послали за доктором? 17. Когда он читает лекции, его слушают с большим интересом. 18. За лекцией последовала горячая дискуссия. 19. Об этой книге много говорят. 20. Кем написано это письмо? 21. Кому показывали эту работу? 


\section{Lesson 2 B. British Universities}

Grammar: Continuous Tense

\section{Pretext Exercises}

Ex. I. Translate the group of words. Mind the suffixes and prefixes:

apply-application-appliance-applied,

educate - education - educational-educated-uneducated,

prepare - preparation-preparative - preparatory-preparedness $p$-preparing,

attend - attendance - attendant-unattended,

differ-difference - different-indifference - indifferent

Ex. II. Translate the pairs of sentences paying attention to the underlined words.

State what parts of speech they are.

1. The children from working-class families have no means to enter the university. I mean that the fees are too high for them. 2. The mention about Cambridge University refers to 1284. It should be mentioned that all Russian higher schools are state institutions. 3. The academic year in Russian higher institutions is divided into two terms. British educationist (educationalist - педагог - теоретик) said that he had already termed his satisfactions with our system of education. 4. Most part-time students in England give their answers during the year in essay their skill in different competitions.

Ex. III. Fill in the blanks with one of the words given in list below.

List: part-time, admission, curriculum, fee, standards.

1. The director said that the number of ... students in our country would be growing. 2. The tuition ... in British universities amounts to 3000 dollars a year in some of the colleges. 3. There exist general rules of... to higher institutions which must be taken by the entrants. 4. There are many schools in England where ... of teaching are very high, but there are schools which are in fact a national disgrace. 3. Society can't afford not to up-date (модернизировать) the school ... from time to time to bring it in line with technological and cultural progress.

\section{British universities}

1. There are 22 universities in Great Britain: 16 in England, 4 in Scotland, 1 in Wales and 1 in Northern Ireland.

2. A university consists of a number of faculties: medicine, arts, law, music, natural science, agriculture, commerce and education. After three years of study, a student may proceed to a Bachelor's degree $e^{1}$ and later to the degree of Master and Doctor ${ }^{2}$.

3. Students are admitted to British universities on the basis of their performance in

\footnotetext{
${ }^{1}$ Bachelor's degree - бакалавр наук, первая ученая степень, присаливается после окончания колледжа или университета

${ }^{2}$ The degree of Master and doctor - ученая степень магистра и доктора наук

Aуmлева Ф.А., Читао И.А., Хатхе А.А., Симбулетова Р.К.
} 
the examinations for the General Certificate of Education ${ }^{3}$. The selection procedure is rather complicated. A student who wants to go to the universities usually applies for admission. First of all he writes to the University's Central Council on Admissions (UCCA) and they send him a form which he has to complete. On this form he has to write down the names of six universities in order of preference. This form, together with two references, one of which must be from the head teacher of his school, is sent back to the UCCA. One or two members of this department will look at this candidate's application: see what he says about himself, look at his marks at the ordinary level examinations, see what his head teacher says about him. On the basis of this, the department may make the candidate an offer or send him a definite rejection. The minimum requirement for admission is the student's passing three examinations on the advanced level.

4. Of the full-time students now attending the English universities three quarters are men and one quarter women. The universities include part-time and full-time students ${ }^{4}$ the latter coming to London only to sit for their examinations. Actually most external students at London University are living in London. The colleges in the University of London are essentially teaching institutions, providing instructions chiefly by means of lectures. The colleges of Oxford and Cambridge, however, are essentially residential institutions and apart from lectures they mainly use a tutorial method. Such method brings the tutor into close and personal contact with the student. Each student goes to his tutor's room once a week to read and discuss an essay which he has prepared.

5. Education of university standard is also given in other institutions such as colleges of technology and agricultural colleges, which prepare their students for degrees or diplomas in their own fields.

6. The three terms into which the British university year is divided are eight to ten weeks. Each term is crowded with activity, and the vacation between the terms-amonth at Christmas, a month at Easter and three or four months in summer-are mainly periods of intellectual digestion and private study.

7. The leading universities in England are Oxford, Cambridge and London. These universities' having great difference is not surprising. They differ in the date of foundation, methods of instruction, ways of students' life, etc. Each university has its own problems, each looks at them in its own way.

There are, however, a number of tendencies which are common to them all. This is the tendency of university study to extend beyond the first degree. Many people thought that the normal course was short in the light of width and depth of the curriculum to be covered. Therefore the further development of post-graduate courses appears to be reasonable.

8. The oldest and most famous universities in England are Oxford and Cambridge. Oxford University was established in 1249. It is international because people from many parts of the world come to study at one of the twenty-seven men's colleges or at one of the five women's colleges. A number of well-known scientists and writers, among them Newton, Darwin and Byron, were educated in Oxford and Cambridge.

9. Speaking about education in Great Britain it should be noted that not many people are able to receive a higher education, as the fees are rather high. The cost of education depends on the college and specialty which one chooses.

\footnotetext{
${ }^{3}$ The general certificate of education -Свидетельство о среднем образовании ${ }^{4}$ part-time and full-time students - студенты заочного и дневного отделения Аутлева Ф.А., Читао И.А., Хатхе А.А., Симбулетова Р.К. 
Oxford and Cambridge are rather far from London and therefore the students have to live at the university hostel or in a private room and the rent is very high.

So it is not easy to get a higher education in Great Britain without one's choosing the parents carefully.

\section{Exercises to the Text}

\section{Ex. I. Complete the following sentences according to the text. Translate them into} Russian.

1. After three years of study a student may proceed ... . 2. On the basis of this, the department ... . 3. Speaking about education in Great Britain ... .4. The colleges of Oxford and Cambridge, however, are ... . 5. Each term is crowded with activity and the vacations between the terms ... . 6... providing instructions chiefly by means of lectures. 7 ... see what he says about himself, look at his marks at the ordinary level examinations ... . 8. Oxford and Cambridge are rather far from London ....

\section{Ex. II. Translate the following sentences using English equivalents from the text.}

1. Процедура отбора довольно сложная. 2. Прежде всего, студент должен написать в главную приёмную комиссию, которая высылает ему специальный бланк для заполнения. 3. Минимальное требование для поступления - сдача студентом трёх экзаменов на повышенном уровне. 4. Как правило, большинство студентов-заочников Лондонского университета живут в Лондоне. 5. Такой метод позволяет руководителю данной группы студентов тесно и лично общаться с каждым студентом. 6. Многие считают обычный курс коротким с точки зрения глубины и объёма получаемых знаний. 7. Говоря об образовании в Великобритании, необходимо отметить, что немногие дети из семей рабочих могут получить высшее образование, так как плата за обучение очень высока.

Ex. III. Agree or disagree to the following statements using the expressions: "Yes, it's right" or "No, it's wrong".

1. After three years of study a student may proceed to a Bachelor's degree. 2. A student who wants to go to university just has to pass entrance examinations. 3. The universities include part-time and full-time students, the latter attending everyday lectures. 4 . The three terms into which the British university year is divided are eight to ten weeks. 5. The British universities differ in the date of foundation, ways of students' life, but methods of instruction are the same in all higher institutions. 6. A number of well-known scientists and writers among them Newton, Darwin and Byron woe educated in Cambridge.

Ex. IV. Find the sentences in the text which tell us about... (see below) and translate them into Russian.

1. The procedure of admission to British universities. 2. Correspondence education in Great Britain. 3. The methods of instruction in British higher institutions. 4. The tendency which is common to all leading universities in England. 5. The possibilities for children of the working-class families to get higher education. 
Ex. V. Answer the following questions.

1. What is the selection procedure in Britain? 2. How many years must a student study to proceed to a Bachelor's degree? 3. What organization is responsible for the admittance of candidates? 4. What does it mean to be a part-time student? 5. What is the difference between the colleges in the University of London and those of Oxford and Cambridge? 6. Are there any institutions in Britain which give education of university standard? 7. Which are the leading universities in England? 8. What do they differ in? 9. What tendencies are common to all the universities? 10. When was Oxford University founded? 11 .Why do the students of Cambridge and Oxford have to live in a private room? 12. How many colleges does Oxford University consist of? 13. What does the cost of education in British Universities depend on?

\section{Ex. VI. Make up sentences:}

1. Procedure, the, selection, rather, is, complicated. 2. The, universities, English, parttime, students, full-time, and, include. 3. Goes, student, each, tutor's, once, his, to, room, a, week. 4. Actually, external, London, most. at. students, University, London, living, in, are. 5.0xford, Cambridge, and, most, oldest, the. England, and, famous, in, universities, are.

Ex. VII. Ask questions to the text, let your neighbour answer them.

\section{Grammar exercises:}

Ex. I. Define the "s" ending: plural of the noun, $3 d$ person sing of the verb, possessive case of the noun.

1. A student who wants to go to the University usually applies for admission.

2. One or two members of this department will look at this candidate's application.

3. The colleges of Oxford and Cambridge are essentially residential institutions.

4. Each student goes to his tutor's room once a week.

5. The cost of education depends on the college and speciality which one chooses.

Ex. II. Ask all possible questions.

1. The oldest and most famous universities in England are Oxford and Cambridge.

2. They send him a form which he has to complete.

3. One or two members of this department will look at this candidate's application.

4. Oxford University was established in 1249.

Ex. III. Make one sentence from the text Passive (Present, Past, Future Indefinite). Mind possible semantic changes.

Model: The work is done by the student.

The work was done by the student yesterday.

The work will be done by the student tomorrow.

Ex. IV. Write out irregular verbs and give their three forms. Translate them into Russian. 
Ex. V. Write out sentences with Passive Voice Constructions.

Ex VI. Choose the suitable verb - predicate. Translate the sentences into Russian.

1. I know you an advanced geography course now.

a) were taking $b$ ) is taking c) are taking

2. Now she difficulty in putting facts in order.

a) is having b) was having c) had

3. Scientists in various countries

a) are working $b$ ) is working $c$ ) worked

4. Meanwhile in the village most people to explain this mystery.

a) was preparing $b$ ) are preparing $c$ ) were preparing

Ex. VII. Add question - tags to the following statements.

1. Your aunt is speaking French. 2. His parents were watching TV when he came into the room. 3. They are dining in the college dining-room. 4. When I saw them first they were walking in the park. 5. Peter's wife is playing the piano. 6.1 am not speaking loudly. 7. He is writing quite legibly.

\section{Ex. VIII. Put the verbs in brackets in Indefinite or Continuous Tenses.}

1. On Saturdays I (visit) my mother. 2 Sh! I (listen) to the radio. 3. Peter (play)football at the moment. 4. In England they (play) cricket in the summer. 5. Maria (dislike) foreign food. 6. I'm sorry (not understand) you. 7. What (Peter do) for a living? "Oh, he (work) in a bank". 8. (You study) hard at the moment, Jane. Yes, and I (study) even harder at weekend .9. The clock (strike) in the next room. 10. Yesterday 1 (return) home rather late. It already (get dark) and it (rain). I (walk) quickly. Cars (pass) me. Suddenly one of them (stop) near me and somebody (call) me. I (recognize) the nice of my friend. He (ask) me to get into the car and five minutes later I (be) at tome. 1 I. Don't be late tomorrow. I (wait) for you in the library at 9 o'clock.

\section{Ex. IX. Translate into Russian.}

1. His telegram arrived when I was leaving home. 2 . When I came the typist was typing the letters. 3. My sister was still sleeping when I got up. 4. I was living in Moscow when the war broke. 5. She cut her finger when she was cutting bread. 6. I was having dinner when he rang up. 7. What will you be doing from six till eight tomorrow? I'll be translating the article for the wall newspaper. 8. I'll still be working when you come back.

\section{Ex. X. Analyse the predicates.}

I wasn't listening.

Mother asked her small daughter who was reading a book:

"What are you reading, dear?"

"I don't know," answered the girl.

"You don't know? You were reading aloud, so you MUST know."

"I was reading aloud, Mummy, but I was not listening," the child explained. 


\section{Ex. XI. Translate into English.}

1. Где твоя кузина? Она играет в теннис. 2. Она хорошо играет в теннис? 3. Да, но её брат играет лучше. 4. Если ты увидишь его, попроси его позвонить мне. 5. Я редко вижу его сейчас, т.к. он готовится к своим экзаменам. 6. Студенты всегда заняты в июне, т.к. они готовятся к экзаменам. 7. Кого ты ждёшь? Я жду свою сестру. Она сдаёт экзамен сейчас. 7. Твоя сестра учится хорошо? Она изучает английский, не так ли? 9. Да, она учится хорошо и хорошо знает английский язык. Посмотри, она говорит с каким-то парнем на английском языке. 10.Что ты переводишь? Я перевожу экономическую статью. 11.Ты всегда переводишь без словаря? 12.Но это лёгкая статья, поэтому я перевожу её без словаря. Обычно я пользуюсь словарём. 13. Джон, что ты там делаешь? Ты ужасно шумишь, а я слушаю радио. 14. Мы собираемся провести каникулы на берегу Чёрного моря. 15.Сегодня я не собираюсь читать. 


\section{Lesson 2 C. Students' life}

Grammar: Perfect Tenses.

\section{Students' life}

In another fortnight I shall have finished my first term at Cambridge. Let me tell you something about undergraduate life and my impressions of it.

At first it was all so confusing and new. There were new customs and words to be learnt, and of course new rules and regulations. But remembering that I was not the only "Freshman" (as first-year students are called) I cheered up and very soon made friends.

There are more than 6,000 students at Cambridge this year, so naturally the Colleges are crowded. Since space is so scarce undergraduates share a study when possible and the authorities try their best to ensure that those living together are suited. I share rooms with a young Englishman named John Smith $w$ ho is studying Spanish. I find we share interests and we get on together well.

The students are mainly English but there are plenty of others, particularly so in the block of rooms in which I live, for my neighbors include a Chinese studying law, an Indian studying English, a Canadian, studying history and a Frenchman studying science. As you can see, there is a variety of races, religions and points of view. But it is strange how quickly all of us have become united in our membership of the College and in our loyalty to it. And how proud we are of its successes!

Our rooms have a pleasant outlook over the College gardens and are pleasingly furnished to suit all the needs of a student. There is even a very small gas-stove on which we make coffee or tea. It is a popular custom here to invite friends along in the afternoon for tea and hot buttered toast and jam. And then, very likely, an argument or discussion develops and we talk and keep on talking with never a thought of our work.

We are free, by the way, to decorate our rooms to suit our own tastes, and it is surprising how soon each room reflects the personalities of the owners. John has a radio so we don't lack music.

To each room there is a manservant who with a woman servant, known as a "Bedder", keeps it clean and attends to the needs of the students living there. These men are known as "Gyps" and take a great interest in us, their "gentlemen". Many of them have been with the College all their lives. A word about the Bedders. In the old days when the Colleges were religious foundations the students were, of course, clergymen, and their life was much more strict and disciplined than now. Friendship with young ladies was forbidden and the only women allowed inside the College were washer-women.

We eat our meals in the College dining-hall, a large room hung with pictures of past Dons of the College. Long tables line the hall and at one end there is a raised platform on which is a special table for the Dons, known as the High Table. It is a great honor to be invited to dine at the High Table - and the food is much better!

At some Colleges there is a curious custom that you may be interested to hear of in relation to dining in hall. It is known as "sconcing". If a student should come late to dinner or not be correctly dressed, or if he should break one of the little unwritten laws of behaviour, then the senior student present may order him to be "sconced". The Butler brings 
in a large silver cup, known as "Sconce Cup", filled with beer which he places in front of the offender, who must drink it in one attempt without taking the cup from his lips (it holds two and a half pints). If he succeeds, then the senior student pays for it, if not. the cup is passed round the table at the expense of the student who has been "sconced" No one seems to know the origin of the custom, but you'll notice there is a sporting side to this rather odd punishment.

Speaking of punishments, in general the discipline is not strict. There are rules, of course, but the undergraduate is treated as a sensible person able to discipline himself and no longer a schoolboy who must be told everything. We can stay out a late as we wish up to midnight, but after eleven o'clock a fine (that is, small sums is imposed. But if a Tutor finds that one of his pupils is staying out late very often, he will want to know the reason.

Discipline out of College is the responsibility of two Dons appointed by the University, called Proctors. Each evening a Proctor with two assistants, called "Bulldogs", in full morning dress and top hats, wanders about the town keeping an eye on the students' behaviour. If he sees a student disobeying the regulation that he must wear a cap and gown (another custom from the time when students were clergymen) he will come up to him and say, "Are you a member of the University, sir?" and if the student runs away in an attempt to escape, then the Bulldogs chase him, and if they catch him (and they are chosen, it is said, because they are good runners), fine him six-and-eight pence.

Apart from fines a student may be punished by being dismissed from the University or by being "rusticated", which means that one term of his residence at Cambridge is not allowed. Since it is necessary to be in residence for nine terms to qualify, this is a severe punishment and is only given for serious offences.

I mentioned the tutor. He is a Don who acts as a parent to the student away from home. He gives advice and help in time of need and is an understanding friend to his pupils. Then there is the Dean, who is in charge of the discipline among the 300 students inside College. Last, there are the Directors of Studies and their assistants, the Supervisors. At the start of term I saw my Director of Studies who arranged times for lessons, called "supervisions", and suggested books to read and classes or lectures to attend. He does what his name implies, he directs our studies. 1 go to five "supervisions", each week of one hour each at which I am taught and have my written work discussed and criticized. This takes place in College, but there are also special Lecture Rooms in Town at which students from all the nineteen Colleges attend. These lectures are voluntary and we go to those we think most useful to us personally. They take place in the mornings, and in the afternoon we are free, although the science students go then to their workshops. I usually work in my rooms or take part in some sport.

Unlike school, most of our work is not done in class but in our rooms or in one of the libraries, and each man arranges his timetable to suit himself, leaving time for other activities apart from study. These are numerous and it's time 1 mentioned some of them.

There are, to begin with, over a hundred societies and clubs; enough for every interest one could imagine. There are religious societies and societies for those who don't believe; political, sporting and dramatic societies, not to mention many others. There is even one only for people with beards! Perhaps the most celebrated is the Debating Society at which undergraduates debate political and other questions with famous politicians and writers. Sometimes these debates are broadcast, reflecting as they do what the youth of Britain is 
thinking and feeling, though in general speakers aim to be witty rather than wise.

Sporting activities are as varied and numerous as the Societies, and as you may imagine, there is keen rivalry between the Colleges. The most popular sport is rowing. At the end of term long, narrow, light boats, rowed by eight men, compete in the "Bump Races". Boats start at short intervals one after another and try to overtake and touch (or bump) the boat ahead Those that succeed move up one place in a table and the College at the top of the table is known as the "Head of a River" - a distinguished honour.

So many things are happening in Cambridge each week that it is impossible to see and do all one would wish. But instead we can read about them, for there is a special weekly newspaper written by undergraduates which reports everything of interest, and the most important events are eagerly discussed by the students over their "elevenses".

At five minutes to eleven the street outside the lecture-rooms is empty. The clock strikes the hour and suddenly, as the lectures end, a great stream of students comes pouring out; a stream that grows into a river as a flood of undergraduates, on foot or on bicycles, their gowns flying behind them, hurry into town for a cup of coffee and a cake - a refreshment known as "elevenses". There are many little restaurants and tea- shops, each with its own student customers. One popular, one has a dance in the mornings which is well attended by those who work late in the evenings.

We drink a great deal of tea and coffee and every subject you could imagine is discussed. Yet with all the variety of opinion, dress, of nations and even sex-for there are two colleges for girl students - I can't help feeling a friendliness and community spirit. The walks into the country, the talks, the games and the work, the traditions and the customs, the jokes, the Gyps, the Dons and Debates - all are part of the wide pattern of student life which would be poorer if any of them was lost.

\section{Пояснения к тексту}
1. loyalty ['loialti]
- верность, преданность

2. to decorate a room to suit smb.'s - украшать комнату по чьему-либо вкусу tastes
3. to lack
4. clergyman ['klə:dzimən]
5. sconce [skons]
6. Tutor ['tju:tə]

7. Dons (сленг) [donz]

\section{Proctors}

- испытывать недостаток, нуждаться

- священник

- штраф (обыкновенная кружка пива) за нарушение правил за столом (в Оксфордском университете)

- университетский учитель, ответственный за учёбу, дисциплину определённой группы студентов

- старейшие преподаватели университета (преимущественно в Оксфорде и Кембридже) - административные лица в университете, в чьи обязанности входит надзор за поведением студентов и наложение дисциплинарных взысканий

Aymreва Ф.А., Читао К.А., Хатхе A.A., Симбулетова Р.К. 
9. in full morning dress and top hats-в полосатых брюках, визитках и цилиндрах 10. Director of Studies

- преподаватели, руководящие составлением индивидуальных планов, занятий для каждого студента и наблюдающие да их выполнением

\section{1.rusticate ['r^stikeit] \\ 12. Supervisors ['sju:pəvaizəz]}

\section{3. "Bump Races"}

\section{Which would be poorer if any of them was lost}

- временно исключать (студента) из университета - руководители практических занятий, студенческих семинаров

- университетское состязание по гребле, согласно правилам лодка пропускается вперёд, если догонит предыдущую, должна стукнуться о неё, отсюда и название состязаний.

- которая была бы беднее, если бы любое из событий (студенческой жизни) отсутствовало.

\section{Exercises to the Text}

\section{Ex. I. Give English equivalents from the text and the situation they are used in.}

1. Впечатления от. 2. Быть переполненным. 3. У нас общие интересы. 4. Ладить, уживаться. 5.Точка зрения. 6. Из окна прекрасный вид на. 7. Пригласить друзей на чай, 8. Ни разу не вспомнили о работе, 9. Украшать комнату по своему вкусу. 10. Не испытывать недостаток в чём-либо. 11. Быть внимательным к чьим-либо нуждам. 12. Мы едим в столовой. 13. Неписаные (законы) правила поведения. 14. За один раз (залпом). 15. Гулять до полуночи. 16. Налагать штраф. 17. Вне стен колледжа. 18. Следить за поведением студентов. 19. Исключить из университета. 20. Не говоря о многих других (обществах). 21. Острое соперничество. 22. С небольшими интервалами. 23. Еженедельная газета. 24. Пешком. 25. Всё, что представляет интерес. 26. Прогулки на природу.

\section{Ex. II. Translate into English using the above mentioned equivalents.}

1. Утром троллейбусы переполнены, поэтому я еду на маршрутном такси. 2. Хотя у нас с сестрой общие интересы, но точки зрения на многие вещи разные. 3. Я живу в комнате с тремя студентами. Из окна комнаты прекрасный вид на горы и речку. 4. Мы ладим хорошо друг с другом и часто приглашаем своих друзей на чай или кофе. 5. Студенты в общежитии свободны украшать свою комнату по своему вкусу. 6 . Мы не испытывали недостатка ни в чём, потому что наши родители были внимательны к нашим нуждам. 7. Когда друзья приходят к нам, мы говорим и говорим обсуждаем всё, что представляет интерес. 8. Студентов британских университетов штрафуют, если они нарушают один из неписаных законов поведения. 9. Когда жарко, я очень хочу пить и выпиваю стакан воды залпом. 10. Вне стен колледжа за поведением студентов следит проктор. 11. Британские студенты могут гулять сколько хотят, но за возвращение после одиннадцати часов на студента налагается штраф. 12. Нельзя переходить улицу на красный свет, вас могут оштрафовать. 13. В еженедельной газете университета пишут многое, что представляет интерес. 14. Многие факультеты совершают пешком или на 
автобусе выход на природу, где разные игры и соревнования с острым соперничеством имеют место. 11. И каждый студент составляет график работы такой, который устраивает его 16. В университете есть общества и кружки для любых интересов, которые можно только представить. 17. К студенту относятся как к взрослому человеку, а не школьнику, которому нужно всё говорить. 18. Руководство старается делать всё возможное, чтобы живущие вместе имели общие интересы и ладили друг с другом.

Ex. III. Find synonyms for the following. Give the situations they are used in the text

A student, two weeks, besides, to run after, penalty, many, graduate from, canteen, cause, dress, to be responsible for, current, participate, concerning, contest between, laundress, discuss political question with, approach, stroll, queer, mean (значить).

Ex. IV. Pick up antonyms to the following words, give the situations they are used in the text Junior (student), mild (punishment), to fail, inside.

Ex. V. Write out compound words from the text, give the situations they are used in the text

1. печь. 2. студент. 3. первокурсник. 4. англичанин. 5. француз. 6. слуга. 7. школьник. 8. расписание. 9. мастерская. 10. джентльмен. 11. прачка. 12. лекционный зал.

Ex. VI. Give derivatives from the following words and the situations from the text.

Man, nature, sure, image, please, person (2), to behave, main, week, particular, sense, response, obey, run, punish, vision (2), use, active, take, fresh (2), friend (2).

Ex. VII. The following statements are wrong. Prove it in 3-5 sentences.

1) Students are never punished.

2) Most of students' work is done in class.

3) Sporting activities are not numerous and varied.

Ex. VIII. Express in one word. Make up sentences using these words.

1. The person who is studying at a college, polytechnic or university; anyone who studies. 2. Private teacher, especially instructs a single pupil or a very small class. One engaged for private instruction; university teacher who guides the studies of a number of students. 3. School for higher or professional education; body of teachers (and) students 'forming part of a university. 4. Usual and generally accepted behaviour among members of a social group. 5. University student working for a bachelor's degree. 6. Training, especially of the mind and character, to produce self-control, habits of obedience. 7 . Watch and direct (work, an organization). 8. University official with various duties, including the maintenance of discipline among students.

\section{Ex. IX. Answer the following questions.}

l. What was the author's impression of Cambridge University? 2. What kind of students are there at Cambridge University? 3. What do the students do when they have free time? 4. Who are Bedders and what legend do you know about them? 5. Say a few words 
about student's dining room and a curious custom connected with it. 6 . What punishments for the breaking of discipline are there at Cambridge University? 7. Why is being rusticated a severe punishment? 8. What are the duties of the Director of Studies? 9. What is supervision and where does it take place? 10. Where do lectures for the students of all the 19 colleges lake place? 11. What societies and clubs has Cambridge University for its students? 12. What is the most popular sport between the Colleges? 13. What is 'elevenses"? What do the students do during this time?

\section{Grammar Exercises}

Ex. I. Translate into Russian paying attention to the tense, aspect form of the predicate.

1. Why have you put on your coat? It is quite warm today. 2. Have you finished your work? Yes, I finished it yesterday. 3. Comrade Ivanov has come. He is waiting for you downstairs. 4.1 don't know the time as my watch has stopped. 5. You have written this exercise badly. Write it once more. 6 . He wrote the exercise badly and the teacher told him to write it once more. 7 . We had come home when it began to rain. 8. The train had already left when he came to the station. 9. When the clock struck twelve he went to bed. 10. It had not stopped raining when we left home.

\section{Ex. II. Answer the questions on the model.}

Model: -1'm describing the picture. And you?

- As for me. I'm not describing the picture. I have just described it.

1. I'm washing the floor. And you? 2. John is looking at a book. And his wife? 3. The students are writing a composition. And you? 4. Your friend is answering the questions. And you? 5. I am taking my last exam. And your sister?

Ex. III. Fill in the gaps with "for, since or during".

1. John has worked here___ 1990. 2.1 have known him__ 2 years. 3. I saw them___my stay in London. 4. He spoke_three quarters of an hour. 5. I stayed there three months. 6. It rained the night.

Ex. IV. Translate into English.

1. Где твоя сестра? Она в библиотеке переводит какую-то статью с английского. 2. Она хорошо переводит с английского? Да, она переводит хорошо и быстро. Она только что перевела две статьи и сейчас переводит последнюю. 3. Твой брат вернулся из Москвы? Да. 4. Когда он вернулся? Он вернулся два года тому назад. 5. Я не видел его с прошлого года. Интересно, он сильно изменился? 6. Этот текст самый трудный из всех, которые мы когда-либо переводили. 7. Вы сделали несколько ошибок в работе. Исправьте их. 8. Сделали ли вы какие-либо ошибки в последней контрольной работе? 9. Я только что просмотрела новый номер журнала "Вокруг Света". В нём две интересные статьи о раскопках в Азии. 10. Я получила этот номер журнала два дня тому назад. Я тогда просмотрела иллюстрации. Но эти статьи ещё не прочла, так как была занята. 
Ex. V. Read, translate, analyze the predicates. Ask each other questions on the text and answer them.

\section{Whang the miller \\ (After GOLDSMITH)}

Whang the Miller was very avaricious. Nobody loved money more than he, and respected only those who were rich. When people talked of a rich man, Whang always said, "I know him very well; he and 1 have been friends since childhood", but when people mentioned a poor man. he always said that he did not know him and had never heard his name before, as he was not fond of many acquaintances. One day as he was thinking how to increase his wealth, he learned that one of his neighbours, Hunks by name, had found a large pot of gold underground after he had dreamed of it three nights running. The greedy miller greatly envied his neighbour's luck and complained every day to his customers that he was unlucky, saying, "I've been working from morning till night for so many years, but I've never found any gold. I wish I could dream like my neighbour!" At last he dreamed one night that under a certain part of the wall of the mill there was a huge pot of gold.

He dreamed of the same pot of money the two succeding nights and was therefore sure that he would find the treasure in the place where he had seen it in his dreams. So he got up early the third morning, went to the mill alone with a spade in his hand, and began to dig under the corner of the wall. He had been digging for three hours when at last his spade struck a broad, flat stone, so large that he could not remove it. He decided that he would go home, (would) tell his wife everything and (would) ask her to help him. So he ran home and told his wife of his dream and of the treasure that was waiting for them under the stone. They both ran back to the place where Whang had been digging and found that their mill, which Whang had undermined by digging, had fallen and was lying in ruins.

$\begin{array}{ll}\text { avaricious [,ǽvə 'rifəs] } & \text { - алчный, жадный } \\ \text { to increase [in'kri:s] } & \text { - увеличивать } \\ \text { greedy } & \text { - жадный } \\ \text { to envy [envi] } & \text { - завидовать } \\ \text { complain } & \text { - жаловаться } \\ \text { I wish I could dream } & \text { - как жаль, что мне не снятся такие } \\ \text { like my neighbour } & \text { - сны, как моему соседу } \\ \text { huge [hju:dъ] } & \text { - огромный, громадный } \\ \text { the } 2 \text { succeding nights } & \text { - 2 ночи подряд } \\ \text { to remove } & \text { - передвинуть } \\ \text { his spade struck } & \text { - лопата ударилась (о большой плоский камень) }\end{array}$

\section{Пояснения к тексту}

\section{Oral Speech Practice.}

Ex. I. Share your student life experience with your former classmate.

Ex. II. You returned to your native town after two years of study at the University of London. Stage a dialogue with your neighbour on the life of students in your country and in Great Britain. 


\section{Lesson 2 D. Оксфорд, как он есть}

Grammar: Continuous, Perfect Passive voice.

Render your annotation to the Russian text in English. The questions will help you.

1. When and how was Oxford founded? 2. Which transport is the most favourite in Oxford? 3. Why can Oxford be compared with the UNO? 4. What custom is there in the University of Oxford concerning borrowing books from the library? 5. Is attendance compulsory or not? 6. How does the tutor direct the student's studies?

\section{Оксфорд, как он есть}

Попасть в Оксфорд засветло не удалось. Но, может быть, это и к лучшему. Готическая громада, столько раз до этого виденная на фотографиях, свалилась откудато сверху то ли с чёрного неба, то ли из глубины столетий, и после прекрасной современной автострады, связывающей студенческий город с Лондоном, казалась чемто загадочным, пожалуй, даже жутковатым.

Машин мало. По видавшим видам мостовым колесят в основном велосипеды. Один нацепил поверх куртки ярко-жёлтую портупею из отражающего свет пластика, другой и вовсе привязал к спине плоский карманный фонарик. Оксфорд - город велосипедный. Здесь всё история. И хотя Оксфорд моложе, скажем, Болоньи и Парижа, считается он городом древним. Ровно восемь веков назад в 1188 году, “доктора разных наук” собрались здесь, чтобы заслушать трактат по истории. С тех пор Оксфорд становится центром науки и образования.

Кого только не встретишь на этих улицах! Действительно, по количеству стран, представленных в Оксфордском университете, он мог бы, если не конкурировать, то уж во всяком случае, приблизиться к уровню ООН. 18\% всех студентов - иностранцы, приехавшие в Оксфорд из 107 государств. Есть здесь и наши. Отбор для поездки на такую стажировку был жесточайший. И не только потому, что у нас слишком много аспирантов, желающих съездить в Англию на 10 месяцев. Собеседование с претендентами проводили сами англичане. А это значит, что их не столько интересовали анкетные данные, социальное положение и партийность, сколько деловые качества, знание языка, актуальность разрабатываемой темы именно для Оксфордского университета.

Четырёх аспирантов из СССР мы нашли на улице Пивоваренной. Здесь нет никакой символики, просто все улочки сохраняют веками свои старые названия.

Надежда Какурина - из МГУ, занимается творчеством Томаса Элиота. Сергей Василовский - из Новосибирска, математик. Сергей Травень - из Московского инженерно-физического института и сам Юрас - физик из Вильнюса. "Собственно говоря, мы можем только поделиться первыми впечатлениями”, - начинает разговор хозяин. "В Оксфорде мы чуть больше недели и заняты пока организационными вопросами. Знакомимся с научными руководителями, будущими коллегами, записываемся в библиотеку. Это, кстати, - целая церемония. По традиции, будущий читатель университетской библиотеки должен, надев мантию, произнести клятву в 
бережном обращении с сокровищами. Причём прочесть её на своём родном языке. Ребятам раздали русский текст, а я - традиция, так традиция, - попросил литовский вариант. И что же вы думаете? Нашли. Отношение к нам самое доброжелательное. Впрочем, к этому располагает система обучения в Оксфорде.

Здесь нет, как у нас, обязательного посещения лекций и семинаров. Студенты сами, по-своему усмотрению выбирают, на что ходить, а на что - нет. С самого начала обучения к каждому прикрепляют научного руководителя, в тесном сотрудничестве с которым, собственно, и проходит весь период учёбы. Мы обговариваем учебные планы, литературу, которую НУжно прочитать, даже командировки в другие города, в которые, возможно.

придётся съездить. За них, кстати, полностью заплатит университет. Раз в две недели надо встретиться с руководителем и представить ему отчёт о работе, наметить новые планы. На лекции можно не ходить, и никто за тобой бегать не станет. Раз в семестр руководитель пишет отзыв о работе студента. И если отзыв этот, скажем, не самый блестящий, следует предупреждение студенту. Второго предупреждения, как правило, не бывает ... Таким образом, их система обучения, - подытоживает Сергей Василовский, основана на индивидуальной, если хотите, штучной подготовке специалистов. И главное в ней - отношение “студент-преподаватель”. Но не думайте, что это слишком расхолаживает. Время, особенно учебное, здесь умеют ценить. С этой целью даже привычная доска заменена слайдом, проецируемым на стену, - сколько драгоценных минут экономится! Да и библиотека работает круглосуточно”.

М. Чикин

“Комсомольская правда” 13.11 .88 г.

\section{Revision Exercises \\ Tenses, Indicative Mood.}

Ex. I. Put the adverbs in brackets into the correct place.

1 I go to the cinema on Thursdays (always).

2. I've seen her before (never).

3. Do you work at weekends (sometimes)?

4. He has been madly in love with her (always).

5. She doesn't go out in the evenings (usually). 
Ex. II. Choose the proper adverbial modifier.

1. I have studied English...

a) for 2 years

b) in 2 years

c) 2 years later

2. We had finished the laboratory work ...

a) at that time

b) by that time

c) some time later

3. We were spending our holiday in the South...

a) last year

b) next year

c) at that time last year

4. I shall have finished the experiment...

a) by this time

b) at this time tomorrow

c) tomorrow

5. She works in the library ...
a) now
b) once a week
c) just
d) just

Ex. III. Use the other two adverbial modifiers in each of the above written sentence, change the predicate correspondingly.

Ex. IV. Choose the proper form of the auxiliary verb.

1. Where ... you usually spend your vacation?

a) do b) have c) are

2. How ... you spend your free time?

a) do b) have c) are

3. What... your plans for this evening?

a) do b) have c) are

4. ... your child often go to the arcade?

a) doesb) has c) is

5. ... your child fond of going to the arcade?

a) does b) has c) is

6. ... you interested in sports?

a) dob) have c) are

7. .... seen you for ages.

a) have not b) did not c) shall not

8. .... see him at the University yesterday.

a) have not b) did not c) shall not 
9. ... you ever been to London?

a) did b) have c) will

10. .... still reading the book,

a) have b) am c) do

11. Listen? He ... in the next room.

a) is singing $b$ ) sings $c$ ) will sing

Ex. V. Translate into Russian paying attention to the Passive Voice..

1. American's first college, Harvard, was founded in Massachusetts in 1636. 2. The students will be tested on the Industrial Revolution at the end of the term. 3. In more than 200 years the USA Constitution has been amended 26 times. 4. The bridge will have been reconstructed by tomorrow morning. 5. The Navy officials said that the dolphins (will be kept) would be kept in salt water holding tanks. 6 . The driver was requested not to drive so fast. 7. Pedestrians are required to cross the road at the zebra crossing. 8. Whose papers are being typed now? 9. When they came the documents had already been typed. 10. Isaac Newton, the greatest scientist of all ages, lived in a period when the toxic effects of chemicals were less understood.

Ex. VI. Translate the following sentences into English. Use passive voice where possible.

1. Зачем ты поливаешь цветы? Они уже политы. 2. Зачем ты переводишь текст? Его перевели вчера. 3. Где ребёнок? Его сейчас купают. 4. О, ты уже написал сочинение! Да, оно только что написано. 5. Я думаю, над ним будут смеяться, если он скажет об этом. 6. Они уже построили свой дом? Нет, он ещё строится. 7. Не входите в аудиторию, там экзаменуют последнего студента. 8. Когда я вошёл, документы уже печатались 9. К этому времени эксперимент будет закончен. 10. Когда мы пришли, эксперимент был закончен. 11. Я могу помочь тебе перевести статью. Спасибо, но она уже переведена. 12. Я могу помочь тебе написать это письмо. Спасибо, но оно только что напечатано. 13. Не опаздывайте! Вас будут ждать. 14. Чьи документы сейчас печатают? 


\section{Lesson 3 A. Great Britain. Geographical position}

Grammar: Complexes with the Participle.

\section{Lexical Commentary}

$\begin{array}{ll}\text { shore } & \text { - берег моря, океана, озера } \\ \text { coast } & \text { - полоса суши, прилегающая к морю (побережье) } \\ \text { beach } & \text { - прибрежная полоса моря (озера), часто песчаная } \\ & \text { или покрытая галькой, заливаемая водой во время } \\ & \text { прилива (пляж) } \\ \text { bank } & \text { - берег реки } \\ \text { channel } & \text { - естественный узкий морской проход между } \\ & \text { двумя берегами, проложить путь, каналы } \\ & \text { получения информации } \\ \text { canal } & \text { - искусственный канал } \\ \text { divide }(\text { into) } & \text { - делить на } \\ \text { separate }(\text { from }) & \text { - отделять от } \\ \text { region } & - \text { район, большая территория } \\ \text { district } & \text { - небольшой район в городе } \\ \text { Island, } \text { isle } & - \text { сфера употребления ограничена рядом } \\ & \text { исторически сложившихся географических } \\ & \text { названий }\end{array}$

\section{Pretext Exercises}

Ex. I. Decipher the following words.

['kbnstitju:t] [kən'sıst] [mailz] [milz] ['meintein] ['mavntın] ['ri:dzən] [kə'næl] ['fænl]

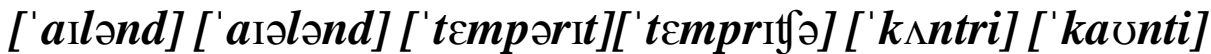

Ex. II. Translate the derivatives, define the part of speech they belong to.

Dense-density-densely, administer-administration-administrative, divide-divisiondivisable, value-evaluate-valuable, geology-geologist-geological, geography-geographergeographical, danger-dangerous-endanger, health-healthy-unhealthy.

Ex. III. Translate into English.

a) 1. Каждый факультет делится на отделения. 2. Наша страна делится на 2 части Уральскими горами. 3. Европа отделена от Азии Уральскими горами. 4. Ирландия отделена от Англии Ирландским морем. 5. Дунай делит Будапешт на 2 части. 6. Будапешт делится Дунаем на две части. 7. Рассвет и сумерки отделяют ночь от дня. 8. Берег реки был покрыт густой растительностью, 9. На берегу моря можно найти ракушки и водоросли. 10. Русская экспедиция приблизилась к берегам Антарктиды 
28/1, 1820 года. 11 Река проложила свой путь сквозь скалы. 12. Манчестер связан с морем Манчестерским судоходным каналом.

в) 1. Северная Ирландия, Англия, Шотландия и Уэльс составляют Соединенное Королевство Великобритании и Северной Ирландии. 2. Евразия состоит из 2-х частей, 3. Разные страны имеют разное административное деление. 4. Административное деление Великобритании - графство, а Австралии и США - штат. 5. Плошадь Антарктиды $-500,000$ кв. миль. 6. Наш университет содержит 2 общежития. 7. Горные вершины спят во тьме ночной. 8. Этот остров необитаем. 9. Северная Ирландия - часть Великобритании.

\section{Great Britain}

A group of islands lying off the north-west coast of Europe is called the British Isles. The largest of the group consisting of some 5 thousand islands are Great Britain and Ireland. Great Britain comprises England, Scotland and Wales. Ireland comprises Northern Ireland and the Irish Republic.

England, Scotland, Wales and Northern Ireland are divided into a number of administrative counties, which put together to constitute the United Kingdom of Great Britain and Northern Ireland. The total area of it is over 244 thousand square kilometres.

In the west Great Britain is washed by the Atlantic Ocean and the Irish Sea, the latter separating England from Ireland. In the South it is separated from the continent by the English Channel. The North Sea washes the East coast of Great Britain.

Great Britain has a very favourable geographical position: the seas connect it with most European countries such as Belgium, Holland, Denmark, Norway, Russia and some others. The main sea route passes through the channel. Being surrounded by seas on all sides, Great Britain is a great sea power. The Britons are proud of their great seamen. One of them is Admiral Lord Nelson, Britain's national hero. It was he who defeated the French fleet at Trafalgar in 1805.

Being an island country, Britain has a temperate climate, largely determined by the Atlantic Ocean. It has winters warmer than on the continent. British harbours are never ice-bound. Britain is notorious for its fogs, which mixed with the smoke of big towns especially in winter-time constitute an unhealthy and dangerous to movement thing. The climate influences British architecture very much. British houses have large windows to let more light through during winter, yet they give little protection from cold: few houses have central heating, double windows are unknown.

Geologically Great Britain is divided into two main regions - Highland and Lowland Britain. Highland is the whole of Scotland, the Lake District in the North-west of England, the broad central upland plain, known as the Penniens, almost the whole of Wales and the south-west peninsula of England. The highest mountains are Ben Nevis in Scotland and Snowdon in North Wales. Lowland Britain is fertile with good arable soil and valuable pasture lands.

Britain is well provided with rivers, but they are too short and are of no value for transport. The longest rivers are the Severn/210/miles and the Thames (200 miles), the latter is navigable for ocean going ships. The main river in Scotland is the Clyde, the Ireland's 
main river is the Shannon. Rivers are joined one to another by canals so that it is quite possible to travel by water from one end of England to other.

Great Britain is one of the most densely populated countries in the world, the average density being 220 persons per square kilometre. The greater part of the population is urban, i.e. $80 \%$ of $60 \mathrm{mln}$ people live in numerous towns and cities.

\section{Exercises to the text}

Ex. I. Give adjectives from the following geographical names:

Europe, Britain, England, Scotland, Wales, Ireland, Denmark, Norway, Russia, Belgium, Holland, America.

Ex. II. Find words of the opposite meaning, give the situation they are used in the text.

Connect, small, narrow, long, sparsely, populated, scantly, impossible, lowest, secondary, rural.

Ex. III. Find words of the same meaning, give the situation they are used in the text.

Contain, nation, make up, entire, principal, wide, earth, town population, mean (средний), famous, motion, are frozen, suitable for navigation.

Ex. IV. Answer the following question.

1. What do we call the 5 thousand islands in the north-west of Europe? 2. Which are the largest islands? 3. What countries does Great Britain comprise? 4. What is the administrative division of the countries constituting the United Kingdom? 5. Great Britain is surrounded by waters of one ocean and two seas, isn't it? 6. What accounts for the fact that Great Britain became a great sea power in the 15 th century? 7. What influences the climate of Great Britain? 8. What is the most unpleasant thing concerning the English weather during winter-time? 9. What is geological characteristic of Great Britain? 10. Which branch of economy is to your mind the most developed in regions fertile with good arable soil and valuable pasture lands? 11. Which are the two longest rivers of the United Kingdom? 12. What does the average density of 220 persons per square kilometre simply? 13. How large is the population of Great Britain? 14. Why are British rivers of no value for transport?

\section{Grammar Exercises}

Ex. I. Translate into English.

1. Группа островов, лежащая к северо-западу от Европы, называется Британские острова. 2. Самые большие острова из этой группы, состоящей из пяти тысяч островов, являются Великобританией и Ирландией. 3. Шотландия, имеющая 186 обитаемых островов, делится на 33 административных графства. 4. Уэльс, состоящий из 13 графств, расположен на западе острова. 5. Как велика группа островов, лежащая к северо-западу от Европы (1/30 размера Европы)? 6. Какие острова из этой группы самые большие? 7. Какие страны расположены на острове Великобритания? 8. Какие государства 
расположены на острове Ирландия? 9. Какова площадь Соединенного Королевства Великобритании и Северной Ирландии? 10. Каково административное деление каждого государства, входящего в Соединенное королевство? 11. Великобритания плотнонаселенное или редконаселенное государство? 12. Какова средняя плотность населения Великобритании? 13. На какие части Великобритания может быть разделена по рельефу? 14. Какая река самая длинная в Великобритании?

\section{Ex. II. Translate the following sentences into Russian. Mind the translation of sentences} with Participle Consruction.

1. London has 14 bridges, the famous London Bridge being among them. 2. In the west Great Britain is washed by the Atlantic Ocean and the Irish Sea, the latter separating England from Ireland. 3. Great Britain is one of the most densely populated countries in the world, the average density being over 220 people per square kilometre. 4 . The wind being favourable, our ship will reach the island in two hours. 5. It was being very cold, they made a fire. 6. The preparations being completed, he began to climb up the mountain. 7. The moon being bright everything was clearly visible. 8. At the presence of moist air copper tarnishes rapidly, its surface becoming coated with brown or green carbonate. 9. There is always water vapour in the air, the amount depending on various conditions 10 . The weather being fine, many families enjoy their meals in the open. 11. The play being popular, we could not get the tickets. 12. The dinner being over, guests went to the garden. 13. My mother being tired, I prepared the supper.

Ex. III. In which of the following three sentences Absolute Participle construction is used. Translate all the sentences into Russian.

1)

a) The two rivers were connected with each other by means of a canal.

b) The Moskva river being connected with the Volga, Moscow became a port of five seas.

c) The railway connecting these two big cities is of great importance.

2)

a) Having introduced the new words the teacher asked one of the students to read them.

b) The new words being introduced, the students read them in chorus.

c) Introducing the new words the teacher explains their meanings.

3)

a) Writing his scientific paper, he had to use a lot of foreign literature.

b) Having written the article, he decided to publish it.

c) The article being translated, he asked us to discuss it.

4)

a) The letter being received, he showed it to the chief engineer.

b) Receiving letters from his foreign friend, he always tells us the news his friend writes him about.

c) Having received their letter he could make an important decision.

5)

a) My friend being ill, I helped him.

b) Being ill I could not finish the work in time.

c) I didn't know of my friend being ill. 
Ex. IV. Combine the given sentences into one, use Absolute Participle construction

1. My sister is ill. I take care of her children. 2. The fruits are washed. Children may eat them. 3. It was dark in the room. I switched on the light. 4. Great Britain is an island country. Its climate is mild. 5. The soup was cold. I could not eat it.

\section{Ex. V. Translate the following sentences into Russian paying attention to Complex Object Constructions.}

1. I saw them approaching the house. 2. While crossing the bridge I saw our students climbing the mountain. 3. Entering the room he saw some people waiting for him. 4. Turning to the left he saw gypsies dancing and singing. 5. I heard him telling them about it. 6. The captain watched the ship being unloaded. 7. We saw them leaving the house. 8. They saw the workers packing the goods. 9. I saw the goods being packed. 10. We watched them repairing the car. 11. We watched the car being repaired 12.They want the goods shipped on Monday. 13. Have you had your watch repaired? 14. I want to have these documents sent off at once. 15. Why have you had the walls of your room painted blue? 16. I must have my shoes repaired. 17. I want to have my TV set repaired. 18. We saw the fire being put out. 19 The passers-by watched the house being pulled down. 20. I've never heard that name mentioned. 21. All of them watched the sunken ship being raised. 22. They said nothing of the kind. I heard the news being announced. 23. None of us noticed the papers thrown away.

\section{Ex. VI. Write out Present and Past Participles from the text, define their functions.}

Ex. VII. Write questions on the italicized parts or on the whole of the sentences:

1) The position of Great Britain gives it a temperate climate. 2) South-westerly winds usually bring mild weather. 3) When the temperature falls, thick mist or fog, comes down. 4) Scotland and Ireland suffer from heavy rainfalls (general, disjunctive). 5) Fog does not come down when the weather is fine (general, disjunctive). 6) The Gulf stream brings warmth to the very doors of English people. 7) The Strait of Dover separates Great Britain from the continent of Europe. 8) The sea gives people much food.9) The Thames is the most important river in Britain because it is suitable for navigation. 10) England and Wales are rich in many necessary minerals.

Ex. VIII. Change the following sentences from Passive into Active.

1. Great Britain is separated from the European continent by the North Sea and the English Channel. 2. England was called Albion by Julius Caesar because of the white cliffs on the English coast near Dover. ("Alba" means "white" in Latin). 3. The way to that pavilion will be indicated by special signs. 4. The ground is covered with snow in winter. 5. The French language was brought to England by the Normans.

\section{Ex. IX. Use subordinate clauses instead of Participle Constructions.}

1. We often speak about our friends living in the south. 2. They spoke about his relatives living in the north. 3. Not knowing the man, I can't introduce you to him. 4. Not remembering the title of the book, we had to look it up. 5. The man arrested was a hijacker (воздушный пират, террорист, угоняющий самолеты) 6.When changed, the article was 
published. 7. If changed, the article will be published. 8. Climbing the mountain he broke his leg. 9. Having climbed the mountain they rested a whole day. 10. The play being popular, we could not get the tickets. 11. The moon being bright, everything was clearly visible. 12. My sister being ill, I took care of her children. 13. It being dark in the room, I switched on the light. 14. Entering the room he saw some people waiting for him. 15. The captain watched the ship being unloaded. 


\section{Lesson 3 B. Great Britain. Economy and largest cities}

Adjective suffixes, degrees of comparison of adjectives.

\section{Great Britain \\ Part II}

Though Britain is not very rich in mineral resources and it imports all of its oil, cotton, rubber, sulphur, 4/5 of its wool, half of its food and iron ore, still Great Britain is one of the most highly industrialized countries in the world. It is a large producer of steel and iron products, electronics, machinery, chemicals; shipbuilding and motor industry are highly developed too. One of the features of Great Britain's foreign trade is the predominance of import over export.

Highlands of Scotland are economically dependent on cattle and sheep-breeding, tourism, fishing. The central Lowlands has many industrial towns based on small coalfields.

The mild climate in Northern Ireland encourages dairy-farming and agriculture. Traditional industries include shipbuilding and food processing.

Great Britain has a lot of industrial cities-Birmingham, Glasgow, Liverpool, Sheffield, Manchester, Leeds, Newcastle and the four capital cities-London, Cardiff, Belfast and Edinburgh.

Birmingham is the second largest city in England and one of the principal industrial centres of the British Isles. Since the XVI c it has acquired the reputation of a metalworking centre, although it had no fuel or ore resources of its own.

Sheffield on the Don River, the 6th largest city of England is known throughout the world for manufacture of cutlery, silverware, electroplated goods, and steel products. It was in Sheffield that stainless steel was invented in 1914.

Manchester and Leeds are chief centres of cotton and woolen industries.

Newcastle is an exporter of coal and ships.

Glasgow, the largest port and trading centre of Scotland, is famous for its shipbuilding yards its iron and steel works and its light industry. The capital of Scotland is Edinburgh with its historic buildings and university. Electronic equipment, the well-known Scotch whisky and rubber goods are produced in Edinburgh.

Cardiff, the capital of Wales, is one of the world's greatest coal shipping ports and the most important industrial and financial centre of the country

Liverpool is the principal port of Western England. It is the first in Great Britain in exports and ranks second after London in imports which consist of textile machinery, electric equipment and chemicals.

Great Britain is a constitutional monarchy. At the head of the state is the queen, but she is a formal ruler; her power is limited by Parliament. Parliament is the supreme legislative body, consisting of two Houses, the House of Lords and the House of Commons. The British government consists of the Prime Minister and other ministers. Prime Minister is responsible for the policy conducted by Parliament. 
The main political parties are the Conservatives supported by the rich and privileged, the Labour Party, founded by the Trade Union Congress at the beginning of the 20th century.

\section{Exercises to the text}

Ex. I. Write out words with silent consonants from the text (not less than 8 words).

Ex. II. Letter combination ch can be read as [J] [k] [t]] write out 2-3 examples for each sound.

Ex. III. Write out the derivatives from the following words.

Source, machine, rule, constitute, industry, dominate, commerce, fame, value, finance, engine, govern, response, produce, economy, courage.

Ex. IV. Write out synonyms for the following words. Give the situation they are used in.

Main, although, one second, as well, many, wealthy, fiscal, manufacturer, fame, all over the world, production, commerce, chamber.

Ex. V. Write out antonyms to the following.

Poor, agricultural, executive, exclude, light, import, independent, severe, heavy, engineering.

Ex. VI. Translate the following words combinations, give the situation they are used in.

Iron ore, navigation equipment, motor industry, ship building, iron industry, steel industry, cotton industry, trading centre, rubber goods, cattle-breeding, food processing, dairy-farming.

VII. Give degrees of comparison of the following adjectives and adverbial modifiers from the text.

Rich, many, highly, principal, famous, great, large, little, broad, high, fertile, valuable, well, important, heavy, light.

Ex. VIII. Translate the following pair of words, which of the two is used in the text. work-works, good-goods, chemical-chemicals, principal-principle, rich-the rich.

Ex. IX. Insert the necessary prepositions.

1. Britain is not very rich ... mineral resources.

2. Prime Minister is responsible ... the policy conducted by Parliament.

3. Sheffield and Birmingham are famous ... their iron and steel industries.

4. Rivers in Britain are very short an of no value ... transport. 
Ex. X. Give a noun related to each verb.

a) to govern, to develop, to move

b) to industrialize, to produce, to limit, to found, to divide, administer, to constitute, to separate, to provide, to determine, to protect, to populate.

\section{Grammar Exercises}

Ex. I. Give adjectives from the following words. Use the given suffixes. Translate the adjectives into Russian.

ful - harm, fruit, play, care, wonder, beauty, event, resource

ous - danger, fame, advantage, continue

able - (прилагательные с этим суффиксом имеют модальный оттенок) тоve, (ible) remark, eat, comfort, sense, change, rely, response

ive - react, response, impress, respect, object, effect

ic - academy, specify, poet, scientist

al - nature, form, spine, physic, music, mathematics

ish, ian, - (прилагательные с этими суффиксами часто обозначают национальность, nese профессию) Finland, China, Portugal, Russia, England, Canada, Australia, Vietnam, Japan, Denmark, Norway, Belgium, Holland

y - sun, wind, rain, cloud, storm

less $\quad$ - (отрицательный суффикс, переводится без ..., не ...)

motion, cloud, job, smoke, sense, tire, end, use

Ex. II. Translate the following word combinations.

Fruitful investigation, a careful mother, an eventful life, a resourceful leader, the wonderful world of nature, a fashionable dress, a readable book, an understandable position, a reasonable argument, a practicable idea, a motionless figure, a tireless struggle, the cloudless sky, fruitless efforts, a careless child, smokeless zones, (useless) effective measures.

Ex. III. a) Group the adjectives according to the forming of their degrees of comparison.

b) Give degrees of comparison of the underlined adjectives.

Busy, dirty, heavy, clever, rare, thin, good, little, old, beautiful, tired, bad, like, near, far, $\underline{\text { real, }}$ salty.

\section{Ex. IV. Choose the proper adjective}

l. My (older, elder) brother took part in the competition. 2. I read the (last, latest) novel by this writer. 3. Excuse me, I didn't hear the (last, latest) word. 4. Read the text (further, farther). 5. Of the three hostels our University maintains the third one is the (farthest, furthest). 6. Jane is the (tallest, taller) of the 2 girls. 7. Father was the (eldest, oldest) of seven sons. 8. The icebreaker is equipped with all the (last, latest) navigation instruments. 9. He bought the toys at the (next, nearest) store. 10. The (next, nearest) house was a new building. 
Ex. V. Translate into Russian paying attention to the degrees of comparison of the adjectives

1. Rugby, the national game in New Zealand, is the most popular sport in Wales. 2. The best known parks near the centre of London are Hyde Park, Regent's Park and St. James's Park. 3. Hyde Park is a large park of 340 acres. In the 16 c King Henry VIII hunted wild animals in the park. 4. Regent's Park is larger than Hyde Park. The London Zoo is in Regent's Park. There are more than 6,000 animals and birds in the Zoo. 5. St. James's Park is the oldest and the smallest of the 3 parks. 6. St. Paul's Cathedral is the second largest church in Europe. 7. The river Thames is one of the longest rivers in England. 8. Eton college is one of England's best known Public Schools. 9. Of no less fame and importance is the British Museum, founded in 1753. It has many departments and one of the most interesting is the library. 11. The most famous older buildings in London include Buckingham Palace (the Sovereign's residence in London), the Houses of Parliament, St. Paul's Cathedral, Westminster Abbey and the Tower of London. 12. Cleopatra's Needle is the oldest monument in London far older than the Tower. 13. Yesterday I translated two more articles, but my cousin translated twice as much. 14. The population of China is much greater than that of the USA. 15. The more you study, the better you know the subject. 16. I like apples, apricots and cherries, but most of all I like walnuts. 17. Australia was discovered later than other continents. 18. The London of 1665 was far smaller than London today.

Ex. VI. Translate the following sentences into English. Mind the degrees of comparison of adjectives.

1. Лекции по педагогике намного интереснее, чем лекции по методике. 2. Зимой дни короче, чем летом. 3. Чем меньше женщину мы любим, тем больше нравимся мы ей. 4. В прошлый раз ты сдал экзамены лучше. 5. В следующий раз приходи со своей старшей сестрой. 6. Я знаю его так же хорошо, как и вас. 7. Когда мне станет хуже, я попрошу тебя помочь мне. 8. Я перевожу тексты быстрее чем ты, а моя подруга переводит ещё быстрее. 9. Эти статьи будут опубликованы в этом журнале меньше, чем через 2 недели. 10. Чем быстрее ты закончишь работу, тем раньше мы пойдём домой. 11. Наши студенты такие же прилежные, как и ваши. 12. Сегодняшняя лабораторная работа труднее, чем вчерашняя. 13. Наши студенты работают в библиотеке так же много, как и ваши. 14. А ты такой холодный, как айсберг в океане. 15. Чем меньше говоришь, тем лучше для твоего больного горла. 16. Чем раньше отправимся, тем раньше придём на место. 17. Эта книга самая интересная в его библиотеке. 18. Этот дом самый красивый в районе. 19. Генри самый старший из трёх братьев. 20. Мой племянник знает столько же языков, что и ты.

Ex. VII. Insert articles where necessary.

1. It was __ latest but not__ last development that had rocked__country.

2. We have finished __ last of _ bread.

3. __ Cambridge is famous throughout __ world as one of __oldest university cities in Britain Oxford, of course, is other (the, the, the). 
4. _ city lies about one hundred kilometres north-east of __ London in that part of England called East Anglia __ flat? Rural area which is known for its wild bird life and fishing (the a).

5. As I drove through _ countryside. most striking phenomenon I noticed was number of small villages with disproportionately large churches__ relic of __ middle ages when East Anglia grew rich on 6. ___ city which is situated on wool trade. (the, the, the the, a). building (the, the).

7. _ crowded street are packed with bicycles (the).

8. But Cambridge is also thriving market town with students going about their business on times, and nowadays it is home to river Cam, is dominated by the magnificent university benefit from their proximity to number of modern hi-tech industries which, of course, (the $, a, a, a)$.

9. Cambridge because of its history and closeness to London, is magnet for tourists (a).

10. __ first book which was written in 1925 was __ story of __ sea (the, the, a).

11. In early nineteenth century Oxford and Cambridge were only two Universities in England (the, the).

12. __ Rugby is most popular sports in Wales (the).

13. __ longest river in world is Mississippi, largest sea is Mediterranean.

Ex. VIII. Choose the correct word from the choice in brackets to fill the gap in.

1. We haven't got __ sugar left (many/much).

2. Go and buy some more eggs, can you? We haven't got __left (many/much).

3. people go out when the weather's cold (fewer/less).

4. He eats ___food that I do (fewer/less).

5. I'm afraid I haven't got _ milk (some/any).

6. I can't lend you any money. I've only got

7. Help yourself to some biscuits. There are myself (a few/ a little). in the tin (a few/a little).

Ex. IX. Ask question to the text.

Check your knowledge of Great Britain.

Can you fill in the empty squares with the correct word?

\begin{tabular}{|l|l|l|}
\hline \multirow{2}{*}{1} & Thames & Shannon \\
\cline { 2 - 3 } & Clyde & ? \\
\hline
\end{tabular}

\begin{tabular}{|l|l|l|}
\hline 2 & London & Belfast \\
\cline { 2 - 3 } & Edinburgh & $?$ \\
\hline
\end{tabular}

\begin{tabular}{|l|l|l|}
\hline \multirow{3}{*}{3} & England & North Ireland \\
\cline { 2 - 3 } & Scotland & $?$ \\
\hline
\end{tabular}

\begin{tabular}{|l|l|l|}
\hline \multirow{2}{*}{4} & 49 counties & 6 counties \\
\cline { 2 - 3 } & $?$ & 13 counties \\
\hline
\end{tabular}




\begin{tabular}{|l|l|l|}
\hline 5 & the whole of Scotland & the North-west of England \\
\hline \multirow{2}{*}{ the whole of Wales } & $?$
\end{tabular}

\begin{tabular}{|l|l|l|}
\hline \multirow{2}{*}{6} & dairy-farming & agriculture \\
\cline { 2 - 3 } & Shipbuilding & $?$ \\
\hline
\end{tabular}

\begin{tabular}{|l|l|l|}
\hline \multirow{2}{*}{7} & cattle-breeding & sheep breeding \\
\cline { 2 - 3 } & tourism & $?$ \\
\hline
\end{tabular}

\begin{tabular}{|l|l|l|}
\hline \multirow{2}{*}{8} & shipbuilding yards & iron and steel works \\
\cline { 2 - 2 } & trading center & $?$ \\
\hline
\end{tabular}

\begin{tabular}{|l|l|l|}
\hline \multirow{2}{*}{9} & Glasgow & London \\
\cline { 2 - 3 } & Cardiff & $?$ \\
\hline
\end{tabular}

\begin{tabular}{|l|l|l|}
\hline \multirow{2}{*}{10} & historic buildings & the well-known whisky \\
\cline { 2 - 3 } & electronic equipment & $?$ \\
\hline
\end{tabular}




\section{Lesson 4 A. London}

Infinitive, its functions in the sentence.

\section{Pretext Exercises}

Ex. I. Read the following words, revise the rules of reading.

Capital, city, full, historic, both, bridge, square, course, chiefly, famous, tomb, stables, thing, built, protect, behead, explorer, armoury, museum, strengthen, chamber, associations, through, monarchs, to crown, burial, particularly, unattractive, cathedral, symbol, commercial,

\section{Ex. II. Read the proper names:}

London, England, the United Kingdom, Downing Street, Fleet Street, Hyde Park, Kensington Gardens, St. James's, the West End, Buckingham Palace, Tower, Piccadilly Circus, Trafalgar Square, Royal, the National Gallery, Westminster Abbey, the Unknown Warrior, the Houses of Parliament, the Stock Exchange, Christie's, Sotheby's, St. Paul's Cathedral.

\section{Ex. III. Choose the suitable form of the verb.}

London (was not built, did not build) as a city in the same way as many other cities. People (built, were built) outside the walls during a long period after the Norman Conquest. The city (was, has been) practically destroyed during the plague and the Great Fire in the seventeenth century.

\section{Ex. IV. Insert suitable words.}

Government, narrow, square, weather, to surround, population, traffic, shopping, number, capital.

1. London is the ... of Great Britain. 2. The ... of Great Britain decided not to spread London farther. 3. The ... of Moscow is over 9 million people. 4 . The ... is very slow in narrow streets. 5. A green belt ... London. 6. There are many ... streets in the workers' districts of London. 7. I went ... yesterday. I bought a very pretty dress. 8. The ... was fine and we went out for a walk. 9. What is the ... of people who live in "the City" now? 10. "The City" is about 26... kilometres.

\section{Ex. V. Ask questions to the underlined words.}

1. The weather changes very often in London. 2. Londoners like to get out of town on Sundays. 3. The Normans conquered England in 1066. 4. The first Norman King built the Tower. 5. The people who live in Great Britain speak the English language. 6. A green belt surrounds London now. 
London is the capital city of England and the United Kingdom with the population of more than 11 million people. It is very old and full of historic associations, customs and traditions. London stands on both sides of the river Thames, through which it became a great port and trading centre. Many bridges connect one part of London with the other. The number of bridges is 14, the famous London Bridge being among them.

It is said that the best way to see London is from the top of a double-decker bus. In this way you can see the main streets and squares, the historical monuments and the numerous parks of the West End (the quarter where the rich live). Visitors who come chiefly for enjoyment are likely to pass most of their time in that part of London. The famous places to see there are Buckingham Palace, the Tower of London, Westminster Abbey, the Houses of Parliament, Piccadilly Circus, Trafalgar Square.

The place now called Trafalgar square was originally the site of the Royal stables, some lodgings, a parish gaol, cottages, an inn and a brew house amongst other things. The north side of the Square is formed by the National Gallery which houses pictures of well known painters both English and from other countries. Joined to it is the National Portrait Gallery containing pictures of almost every famous English man or woman, writers, artists, inventors and soldiers.

London has a number of Royal Palaces, but only one, St. James's, was actually built as a palace, the others being originally private houses of the nobility. Buckingham Palace, the royal residence, was built by the Duke of Buckingham, later it was bought by George III, who moved there from St. James's.

The Tower of London, situated on the north bank of the Thames, dates from the Roman times. It was strengthened by William the Conqueror to keep control over the city and protect Londoners from the invasion by the river. At one time it was a royal residence and the main state prison. Many great men were beheaded in the Tower. Among them was Sir Thomas More - the author of the famous "Utopia", Sir Walter Raleigh, explorer and historian, founder of the first English colony in America (1584). Now it is a barracks, an armoury and a museum.

Westminster Abbey at which all English monarchs since William the Conqueror, except Edward $V$, have been crowned is known as a burial place of many famous people. It is crowded with memorials and tombs. The south side of Westminster Abbey known as Poet's Corner is particularly interesting for many of the greatest English writers are buried here. You can see the memorials to Shakespeare, Byron, Thackerray though not buried here. There is also the Tomb of the Unknown Warrior.

Across the road from Westminster Abbey one can see the Houses of Parliament, the building in which the British Parliament sits. Parliament consists of 2 chambers - the House of Commons and the House of Lords. The Houses of Parliament are famous for their huge clock Big Ben.

Those wishing to leam about London's history will find much to interest them in the City. It occupies a little more than a square mile but it is the heart of business and financial life of the country. It is the oldest part of London with the history of almost 2000 years. Here is St. Paul's Cathedral, the second largest church in Europe. It is round St. Paul's Cathedral that the original London is situated. 
About half a million people work in the City, but only less than 6000 live here. There are a lot of banks, offices, business firms and the Stock Exchange. It is the insurance centre of the world. The bank of England created in 1694 and nationalized in 1946, remains a symbol of finance.

London is also a leading international auction market for works of art through the sales at Christie's and Sotheby's.

To the east of the City is the port of London., where today are miles and miles of docks, and the great industrial areas that depend upon shipping. This is the East End of London, unattractive in appearance, but important to the country's commerce.

\section{Exercises to the text}

Ex. I. Give English equivalents and the situations they are used in the text.

1. Короновать в соборе. 2. Здание, в котором заседает британский парламент. 3. Парламент состоит из Палаты общин и Палаты лордов. 4. Желающие ознакомиться с историей Лондона. 5. Чрезвычайно интересное. 6. Центр страхования, 7. Международный аукцион произведений искусства 8.Вторая по величине. 9. Исторические памятники. 10.Исторические ассоциации. 11. Благодаря которой он стал важным портом. 12.Таким способом можно. 13. Проводить большую часть времени. 14. Резиденция короля. 15. Одно время (однажды). 16. Контролировать город. 17. Защитить город от вторжения со стороны реки. 18. Место, называемое сейчас.

Ex. II. Write out words of the same root.

Invade, associate, joy, head, history, memory, know, busy, finance, origin, industry.

\section{Ex. III. Translate into English.}

1. Лондон - экономический, политический и культурный центр, один из крупнейших портов страны и крупнейших городов в мире.

2. Самые знаменитые древние здания - Лондонский Тауэр, Вестминстерское аббатство, собор Святого Павла, Парламент, Букингемский дворец.

3. Лондон был небольшим римским городом.

4. Вест Энд - район магазинов, офисов, театров, район богатых людей.

5. В Сити сконцентрированы банки, офисы, в том числе Королевская Биржа и Банк Англии.

6. В Ист Энде живут рабочие.

7. В Вест Энде лондонцы приезжают развлекаться.

8. В Вестминстерском аббатстве, где проводятся все коронации, находятся мемориалы известным людям.

9. Букингемский дворец - официальная лондонская резиденция английской королевы, он известен также сменой караула.

10. Шедевр сэра Кристофера Рена, собор Св. Павла, увенчан огромным куполом.

11. Лондонский Тауэр, построенный для защиты Лондона, был крепостью, дворцом и тюрьмой. 
Ex. IV. Answer the following questions.

1. Thanks to what did London become a great port and trading center? 2. Into what parts can London be divided? 3. What is each of the parts famous for? 4. What are the main tourist attractions in the West End? 5. Which of the royal residences was built as a palace? 6. When and by whom was the Tower of London built? 7. By whom was it strengthened and for what purpose? 8. What were the functions of the Tower of London during its 2000-yearold history? 9. What is the Tower of London nowadays? 10. Where are all English monarchs crowned? 11. What else is this place famous for? 12. What are the two houses of the British Parliament? 13. Which of them is supported in the rich and privileged? 14. Who will spend most of his time in the city and why? 15. Which part of London is very important to the country's commerce?

\section{Ex. V. Render the following text in English.}

Сити - район огромных контрастов и даже противоречий (contradictions). Это Английский банк (Bank of England) и фондовая биржа (Stock Exchange), Собор Святого Павла и десятки других церквей, построенных Кристофером Реном (Christopher Wren) в его особом стиле. Это стены Тауэра, одного из величайших сооружений в истории Лондона. Здесь можно увидеть как узкие улочки с высокими мрачными зданиями викторианской эпохи (Victorian Age), так и широкие проспекты и площади с современными зданиями из бетона (concrete) и стекла. Это смешение (mixture) исторических эпох наиболее ярко проявляется в церемонии вступления в должность (inauguration) Лорда-мэра (Lord Mayor). Церемония проводится ежегодно в ноябре после выборов (elections) нового Лорда-мэра.

Избранный Лорд-мэр проезжает по улицам Сити в золочёной карете (gilded coach), приветствуя жителей Лондона. Должность Лорда-мэра была учреждена в 1191. Лорд-мэр избирается на один год и выполняет много почётных обязанностей. Он возглавляет Корпорацию Лондона (London Corporation), управляет (governs) Сити через Муниципальный Совет (Municiple Council). Он является главным судьёй полицейского суда (police court) Сити, главным (admiral) Лондонского порта и первым гражданином столицы. Наряду с этим он продолжает заниматься своей личной профессиональной деятельностью. Таким образом, год, который он проводит на своём посту, становится чрезвычайно насыщенным.

Площадь Сити - 1 кв. миля (square mile). В будни здесь сосредоточено свыше 400 тыс. человек, хотя число постоянно проживающих лиц не превышает 4 тыс. человек.

\section{Grammar Exercises}

\section{Ex. I. Define the aspect, tense form of the Infinitive (Indefinite, Continuous, Perfect,} Passive or Active).

1. I like to read books by this writer. 2. My little niece likes to be read fairy-tales. 3 . To be presented with flowers was very pleasant for her. 4. You must be feeling rather tired having worked in the garden for 2 hours. 5. Today mankind can survive only if it sees wars as a common misfortune. 6. He must have been an excellent swimmer years ago. 7. He is 
glad to be training young sportsmen again. 8. He was fortunate to have been taken to hospital immediately.

\section{Ex. II. Define the function of the Infinitive.}

1. They are to read this book next term. 2. Her wish is to read the book by this writer. 3. To read this book is very useful. 4. To read this book he went to the library. 5. To solve this problem is externally important. 6 . To solve this problem you have to make a great many experiments. 7. To drive a car in a big city one must be an experienced driver. 8. To drive a car in a big city is very difficult. 9. It takes me half an hour to get to the university. 10. To get the new magazine I had to go to the library. 11. To prevent corrosion metal must be covered with paint. 12. Press the button to set the machinery in motion.

\section{Ex. III. Finish the sentences using the Infinitive as subject or adverbial modifier.}

$\begin{array}{ll}\text { Model: To pass this term exams: } & \begin{array}{l}\text { a) is my wish } \\ \text { b) he reads much }\end{array} \\ \text { 1. To translate the text: } & \begin{array}{l}\text { a) } \\ \text { b) }\end{array} \\ \text { 2. To complete the experiment: } & \begin{array}{l}\text { a) } \\ \text { b) } \\ \text { 3. To know this rule: }\end{array} \\ \text { 4. To buy a new car: } & \begin{array}{l}\text { a) } \\ \text { 5. To set the machinery in motion: }\end{array} \\ & \text { a) } \\ & \text { a) } \\ \end{array}$

Ex. IV. Insert "to" before the Infinitive where necessary. State the function of the infinitive. Translate the sentences into Russian.

1. There is a man downstairs who wants (to see) you. 2. Everything was done (to save) him. 3. May I (to use) your phone? 4. Peter, can you (to come) to tea tomorrow? I'm sorry, Nick, but I can't (to manage) it. 5. I had (to go) to the library yesterday as I didn't have the book needed for (to) the seminar. 6. You had better (to call) him up once more. He might have returned home. 7. Could you help me (to do) the washing now? 8. We have never known him (to lose) his temper before. 9. He had a bad headache and I made him (to take) some medicine. 10. I am anxious (to continue) my work. 11. The boys got up at 6 o'clock, not (to miss \} the train. 12. Could you let me (to do) it alone? 13. I saw her (to leave) the room. 14. I don't know what (to tell) him. 15. My son asked me (to let) him (to go) to the theatre. 16. I made him (to read) the story.

Ex. V. Translate the sentences into Russian. Define the function of the infinitive.

1. It is very difficult to translate this text without a dictionary. 2. It is too late to go for a walk. 3. They are to read this book next term. 4. His wish is to read this novel translated into Russian. 5. He wants to be invited to the party. 6 . They will have to repair the equipment in five days. 7. Mendel was the first to introduce new principles in studying heredity. 8. Mendeleev was the first to invent the periodic table of elements. 9. We have a lot of problems 
to solve. 10. To read this novel was like swimming in a lake so clear that you could see the bottom. 11. He is not competent enough to take part in the expedition. 12. It is too cold today to sleep with an open window. 13. To calculate the age of our planet one must have much knowledge in different branches of science. 14. To find the mass of the electron numerous experiments had to be made. 15. If we are to win this match, we must all do our very best. 16. When I was translating these articles I had several dictionaries to help me. 17. Historically groups of people have always traded with other groups to obtain goods that were not available locally.

\section{Ex. VI. Translate the sentences into English using the Infinitive.}

1. Кататься на коньках приятно. 2. Его цель - научиться говорить по-английски. 3. Я пришёл сюда, чтобы научиться играть в футбол. 4. Здесь можно увидеть многое. 5. Она пошла домой, чтобы пораньше лечь спать. 6. Где мы должны встретиться? 7. Вы не должны пропускать уроки. 8. Мы рады вас видеть. 9. Я не знаю, как доехать до его дома. 10. Кажется, что все студенты готовы отвечать на мои вопросы. 11. Мы надеемся встретить вас в субботу. 12. Что она решила делать во вторник утром? 13. Чтобы хорошо знать иностранный язык, надо много работать. 14. Два дня достаточно, чтобы съездить в Петербург. 15. Он просил разбудить его рано. 


\section{Lesson 4 B. London Streets and Parks}

\begin{tabular}{|c|c|c|}
\hline Trafalgar Square & [trə’fælgə] & Трафальгарская площадь \\
\hline Waterloo & [wว:tə’lu:] & Ватерлоу \\
\hline Chancellor & 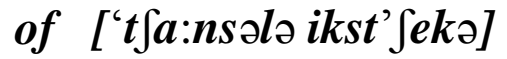 & министр финансов \\
\hline
\end{tabular}

Exchequer

Downing Street [,dauningstri:t]

Piccadilly Circus

Cenotaph

Charring Cross

Soho

Vantage point

Regent's Park [,pikə’dili'sə:kəs]

['senouta:f]

['tfeərinkro:s]

[sou'hou]

['va:nti:d3 'point]

['ri:dzənts pa:k] улица, на которой находится министерство иностранных дел и официальная резиденция премьер министра

площадь Пикадилли

пустая гробница, памятник неизвестному солдату

удобная позиция, пункт наблюдения

\section{London Streets and Parks}

People who read books by English writers, listen to the radio, see English films can't help knowing such names as Trafalgar Square, Downing St., Whitehall Fleet Street, Piccadilly Circus, Charring Cross, Soho, Oxford and Bond.

Let's begin with Trafalgar Square. There is a monument there called the Nelson Column. It is a special memorial to one of England's greatest seamen Admiral Lord Nelson. Equally famous is the general who led the army at the battle of Waterloo in 1815. This was the Duke of Wellington. His house stands at Hyde Park Corner. It is sometimes known as Number One, London. Like Admiral Nelson, the Duke of Wellington is buried in St. Paul's Cathedral.

On the south of Trafalgar Square there is a little but quiet street Downing Street. It is a very famous street. For the last 200 years at number 10, each Prime Minister of England has lived. Next at No 11 lives the Chancellor of Exchequer.

In the middle of the road opposite Downing Street is the simple but impressive Cenotaph, the memorial to the men who died in the two World Wars. Just along there on the left is New Scotland Yard, the headquarters of Police, known to all who read detective stories.

Piccadilly Circus is a fine street which has seen much history over the centuries. For generations Piccadilly has been the heart of London. Nowadays it is such a focal point that on special occasions such as Coronation or on New Year's Eve, as many as 50,000 people gather there. Actually it immortalized a man who is now forgotten. The man was a tailor who grew rich by making high collars called "piccadillies". 
Charing Cross is one of the oldest spots in London. Once there was a small village in that place. The villagers were charring wood, making charcoal of it. That is why the village was named Charing. In 1291 Elenor, the English Queen, died outside London. Her husband wanted her body to be taken to Westminster Abbey and buried there. At every place where the funeral procession stopped a wooden cross was erected. The last place was at Charing and since then the place is called Charing Cross. Nowadays Charing Cross Road is known by its bookshops where one can buy books in different languages and of new and old editions.

From Piccadilly Circus, the centre of London's gaity, you can go along the shops of Bond Street, where you can buy extremely nice things but they are the most expensive. One of the most animated streets in London is Oxford. There are lots of shops in it and things are not that expensive.

Soho is the district where one can see people of different languages. It is famous for its various restaurants. There are some short streets in Soho, in which six or seven restaurants of different national cooking stand one after another in line. One can have breakfast in a Greek restaurant, dinner - in Italian, supper - in Armenian.

The Strand once the bank of the River Thames is one of the oldest streets in London. Now this street is a link between the City and the West End, it leads to Fleet Street where all newspapers have their offices.

At heart the English are not really town folk but country lovers, and what they like best in their cities are their parks and gardens. The art of gardening has a very old tradition in England. There are more than 80 parks in London. The best known parks near the centre of London are Hyde Park, Regent's Park and St. James's Park.

Hyde Park is the largest and the most popular and the most many-sided. It is a garden where you walk or sit on the lawns.

Regent's Park is the most countrified of London parks. With its several islands covered with trees and a tangle of shrubbery, the ornamental water it somewhat resembles St. James's Park though it is on a larger scale. It rivals St. James's in the number and rare kinds of its water-birds.

St. James's Park affords a variety of interest in spite of its small scale. One can appriciate the gay flower-beds, the exotic water-fowl, the little lake and the trees so artfully disposed by John Nash that they seem to become a spacious natural landscape. It is a vantage point from which to obtain unique glimpses of London's buildings of Buckingham Palace and the Victoria memorial casting their reflections in the waters of the lake.

\section{Ex. I. Find English synonyms for the following and give the situation they are used in the text. \\ Main place, event, collect, connection, bush, to be like, convenient observation place, despite its small size, case, decorative, glance.}


Ex. II. Answer the following questions.

1. What are the channels of getting information about London streets and parks? 2. What is Trafalgar Square now and what was it originally? 3. At what battles did Admiral Nelson and general the Duke of Wellington become famous and where are they buried? 4. What is Downing street famous for? 5. What is situated on the left of Cenotaph? 6. Whom did Piccadilly Circus immortalize and why is it the heart of London? 7. What is Charing Cross noted for? 8. What street is the centre of London's gaiety? 9. Which is the most animated street in London? 10. What is Fleet street noted for? 11. Which park near the centre of London is the largest and the most popular? 12. What does it look like? 13. Which of the 3 parks near the centre of London reminds rural areas? 14. What is St. James's Park noted for? 15. Thanks to whom did the park become a spacious natural landscape? 16. From what place can one obtain unique glimpses of London? 17. What famous London buildings are reflected in the waters of St. James's lake?

Ex. III. Analyse the verbals in the text, give analogous examples.

Ex. IV. Retell the text. 


\section{Lesson 4 C. От Лондиниума до Лондона}

\section{Grammar: Gerund, its functions in the sentence.}

Время мало что оставило от того Лондона, который, был основан римлянами после завоевания ими Британии. Тем ценнее каждое новое открытие археологов, которые ведут раскопки на территории английской столицы, по крупицам воссоздавая прекрасный образ города, по праву считавшегося жемчужиной Римской империи.

У Тацита мы узнаём, что в 60 годы н.э. Лондиниум (римское название Лондона, который с $\boldsymbol{I}$ по $\boldsymbol{V}$ век являлся центром провинции Британия) был переполнен торговцами и представлял собой крупный центр торговли. Но для того, чтобы доказать, насколько прав был римский историк, понадобилось семь лет лихорадочного труда крупной археологической экспедиции.

Самым замечательным достижением лондонских археологов стало доказательство того, что расцвет Британской провинции исторически обоснован. В Британии римляне действовали планомерно, и ключом к осуществлению их планов был Лондон.

После того, как длительный поход Юлия Цезаря в 55 году до н.э. нарушил соотношение сил между племенами, населявшими южную Англию, Темза превратилась, по-видимому, в границу между враждующими племенами и перестала служить естественным связующим и торговым путём из глубинных районов вниз к морю и портам континента. Высадившиеся в Британии римляне стали продвигаться вверх по Темзе. Важной целью этого похода был разгром племени, которое господствовало в районе Колчестера. Римлянам удалось переправиться через реку, возможно, вброд в районе Вестминстера, дойти до Колчестера и захватить его, обеспечив этим триумф своему императору Клавдию.

От брода у Вестминстера легионеры-разведчики могли увидеть прекрасный плацдарм, для следующего этапа завоеваний - огромную глубокую заводь, 2 невысоких холма, возвышавшихся над затоплявшейся во время паводков равниной. Между холмами протекал ручей, который всегда мог служить источником свежей питьевой воды, длинный прямой отрезок берега был пригодный для пристаней. Эти особенности местности отвечали всем критериям, которых придерживались римские зодчие.

C самого начала римляне планировали построить большой город. Занимая 330 акров Лондон был таким же крупным, как Париж тех времён или даже Трир, большой гарнизонный город, где стояли римские легионы. Были построены дворец наместника, храмы, форумы, общественные и частные здания, многочисленные лавки, были проложены дороги.

К 2000 году английские археологи надеются изучить 25\% территории Лондона времён Римской империи.

За рубежом. № 16. 1982 г. 
Render the above written text in English and retell your rendering.

\begin{tabular}{|c|c|}
\hline \multirow{2}{*}{\multicolumn{2}{|c|}{ - Tacitus [tæsitəs] }} \\
\hline & \\
\hline лихорадочный & - hectic \\
\hline достижение . & - achievement \\
\hline \multicolumn{2}{|l|}{ служить } \\
\hline доказательством & - to evidence \\
\hline обоснованный & - well-grounded \\
\hline планомерно & - systematically \\
\hline глубинный & - remote, out-of-the-way \\
\hline \multicolumn{2}{|c|}{ переправиться вброд - to wade, to ford } \\
\hline плацдарм & - bridgehead, base \\
\hline заводь & - backwater, creek \\
\hline паводок & - flood, freshet \\
\hline затоплять & - submerge \\
\hline питьевая вода & - drinking water \\
\hline пристань & - pier, wharf [wo:f] \\
\hline зодчий & - architect \\
\hline гарнизон & - garrison \\
\hline $\begin{array}{l}\text { отвечать требованиям } \\
\text { прокладывать дорогу }\end{array}$ & $\mathrm{M}$ - meet the criteria \\
\hline
\end{tabular}

Translate the following dialogue into English and stage it.

$\boldsymbol{A}$ - Я знаю, что на днях ты поедешь в Лондон. Это будет твоя первая поездка в Великобританию, не так ли?

В - Точно. Я бы хотел знать, какие достопримечательности ты мне советуешь посмотреть.

А - Видишь ли, всё зависит от того, как долго ты сам сможешь пробыть, и от твоих интересов.

В - Я там пробуду не более трёх дней. Что касается моих интересов, я увлекаюсь искусством.

А - В таком случае, ты должен посетить Национальную Галерею. Там очень много картин известных художников.

В - Я последую твоему совету. Это у меня займёт весь день, не так ли?

А - Безусловно. Ты должен посмотреть Букингемский Дворец, где живёт

Королева. Тебе будет интересно понаблюдать смену караула перед

Дворцом.

В - Это само собой разумеется. Чем известна Трафальгарская площадь?

А - Она расположена в центре Лондона. Там есть памятник адмиралу

Нельсону, который одержал победу над французским флотом при

Трафальгаре в 1805 году.

В - Мне бы хотелось повидать памятники древней архитектуры: Собор

Святого Павла, Тауэр, здание парламента и много других.

А - Ты думаешь, я всё успею посмотреть? 
В - Думаю, что да. Ты сможешь пойти в Гайд парк, где проходят митинги.

А - Благодарю тебя за ценные советы.

\section{Grammar Exercises}

\section{Ex. I. Translate the following sentences into Russian. State the aspect form of the Gerund and its function.}

1. I don't like reading. 2. My little niece is fond of being read. 3.1 did not know of my cousin's having been sent to London. 4 . He is responsible for the work being finished in time.5. I remember his telling me about it a few days ago.6. The rain prevented me from coming earlier. 7. The doctor suggested the family moving to the South. 8. Her having sprained the ankle prevented her from participating in the competition. 9. When I am on holiday I enjoy not having to get up early. 10. They were in the habit of going abroad in summer. 11. Most substances contract on changing from the liquid to the solid state.12. People who read books by English writers or listen to the radio see English films can't help knowing such names as Trafalgar square, Piccadilly Circus, Charing Cross. 13. He has given up smoking.14. If you won't tell me what is wrong, what is the use of my being here. 15. You can improve your English by reading more. 16. It's nice to go on holiday without having to worry about money. 17. Our team lost the game in spite of playing well. 18. It's a nice morning what about going for a walk. 19. What did you do after leaving school? 20. I'm not very good at learning languages. 21. What are the advantages of having a car? 22. Before going out, I phoned my friend. 23. It's not worth going shopping now. By the time we get to the shops, they will be closed. 24. She experienced a strange feeling of being watched.

Ex. II. Translate into Russian. State which ...ing...form is Gerund. Give your grounds.

1. She put the sleeping child on the sofa and went to the window. Sleeping with the open window enjoys me greatly. 2 . The boiling kettle whistled its warning. The boiling temperature of different substances depends on their density. 3. These running shoes are a bit tight across the toes. The running children are senior form pupils. 4. The young man writing at that table is my former school-mate. The writing paper I need should be of better quality. 5. I am afraid of swimming in deep rivers and lakes. The swimming man must have been a famous sportsman years ago.

\section{Ex. III. Insert not + participle or without + gerund. Translate the sentences into Russian.}

1. I wouldn't say such a thing - being sure. 2 . She filled the cup with fragrant tea then put it on the table - knowing whom to offer it first. 3. - finding what he wanted, he looked slowly about the room. 4. - finding his new address we can $t$ send him the invitation. 5. - knowing what to reply, I remained silent. 6 . We walked - speaking for a short while. 7. I don't want to go abroad - seeing you. 8. He sat down - taking off his mackintosh.

\section{Ex. IV. Use the Infinitive or Gerund of the verbs in brackets.}

I. I'd prefer (go) to the theatre tonight rather than to the cinema. 2. Jane has no gone on holiday yet. I remember (see) her yesterday evening. 3. We all helped (do) the shopping. 4. I'd advise you (get) your hair cut before (go)for such a very important interview. 5. I am tired of (sit) here (do) nothing. 6. I had no money, so I had no choice but (sell) my car. 
7. I won't allow you (talk) to me like that. 8. I regret (tell) you about this. But I must. 9. I regret (have told) you about it. 10. I really must stop (smoke). 11. On seeing his friend he stopped (talk) to him.12. I can't help (laugh) whenever I see a Charlie Chaplin film.13. I am interested in the problem of (train) specialists in the University. 14. Marlin stopped (read), turned off the light and went to sleep. 15. Maria tried (learn) English, but she found it difficult and gave it up. 16. If you've got a headache, you should try (take) aspirin. 17. If you see Susan, can you remember (ask) her to come and see me? 18. I can remember (write the letter yesterday, but I can't remember (post) it. 19. I'm sorry but I'm so busy that I can't help you (do) the washing up at the moment. 20. I was surprised (hear) that he has got a new job. 21. I was surprised at (he fail) the examination.

Check your knowledge of London, what is it?

1. It is the largest industrial and cultural centre of Great Britain and a very big port. In Roman times it was a great trading centre.

2. This place is a historical reminder of the naval victory won by Great Britain over Napoleon. This place is considered to be a geographical centre of London.

Today it is famous for its flocks of pigeons and is used as a meeting place for rallies.

3.It is the commercial and financial centre of London and indeed of the whole Commonwealth, very few people actually reside there.

4. This building is the seat of the British Government.

5. It is a group of ancient buildings. At one time it was a fortress, a royal residence, a prison. Now it is a museum.

6. It is one of the oldest buildings in London. It is not only a cathedral and the place where monarchs are crowned, but also the resting place of famous statesmen, scientists, poets and musicians.

7. It is the most famous and the largest park in the West End of London.

8. It is the park with islands covered with trees and shrubbery.

9. It is the smallest park near the centre of London noted for its exotic water-fowl. 


\section{Lesson 5. Adygheya}

Grammar: Infinitive and Gerund Compared.

Words to be remembered

1. middle ages

2. links

3. Great Silk Route

4. barrow

5. access

6. mode of life

7. rebuff

8. code of honour

9. reservoir ['rezəvwa:]

10. food processing industry

11. mechanical engineering

12. scent and oil-yielding plants

13. poultry farming

14. wheat [wi:t]

15. barley [ba:li]

16. corn [kO:n]

17. horticulture

18. horse-breeding

19. to increase [ink'ri:z] -
- средние века

- связи

- Великий Шелковый путь

- курган

- доступ

- образ жизни

- (давать) отпор

- кодекс чести

- резервуар

- перерабатывающая промышленность

- машиностроение

- эфиро-масличные культуры

- птицеводство

- пшеница

- ячмень

- кукуруза

- садоводство

- коневодство

- увеличивать

The Republic of Adygheya extends from the Kuban river to the picturesque slopes of the western Caucasus. It takes its name from the Adyghes, the ancient settlers of the northwestern Caucasus known to the 13th century Europe as the Circassians. This is a legendary place famed from Europe to Asia in the middle ages and the site of celebrated archeological remains (67 in number) which testify to the region's ancient links with Europe and Asia. The Great Silk Route passed through the country. One can find here dozens of barrows and the mysterious dolmens which are typical of not only the Caucasus but some North European countries too. The rich fauna and flora, the warm climate and the abundance of rock shelters have attracted people to the area since it was first discovered.

Rich natural resources, direct access to the sea and the passage to Transcaucasia attracted foreign invaders to Adygheya throughout its history. The above said accounts for the entire mode of life of the Adyghes that of the rebuffing of enemies. The people had to be worriers in any place at any time. Thus code of honour for a knight on horseback was formed.

Since 1922 Adygheya has been part of different territorial formations in the south of Russia - an autonomous region (1922), an independent member of the Russian Federation 
(1937), part of Krasnodar Territory (1991). In March 1995 it became a republic and elected its President and parliament to form a government.

About 450,000 people of various ethnic groups live on its territory of 7,800 square kilometres.

Forests covering $40 \%$ of the republic's territory are the main suppliers for woodworking and furniture making industries in the North Caucasus.

Adygheya is well provided with water resources: the Kuban with its tributaries the Laba and the Belaya, the Krasnodar artificial reservoir and a number of other small rivers that channelled the ir way through rocks, giving beauty to the country. Unique mineral and thermal waters noted for their healing properties, and natural facilities available for mountaineering, alpine skiing, gliding, trekking, canoeing create perfect conditions for developing tourism and a range of sanatoria and spas. Today Adygheya is an agricultural country, with rather well-developed food processing industry, mechanical engineering and metal working.

Its agriculture is determined by the Republic's fertile soil and favourable climate conditions, the latter being temperately warm and humid, with mild winter. The main crops cultivated in the Republic are wheat, barley, com, rice, sunflower and many scent and oil-yie ld ing plants. The once forgotten branch that of horse-breeding is being revived in Adygheya. Poultry farming is a major is a major agricultural branch.

The Maikop Experimental Station of All-Russian Horticulture Institute was established in Adygheya some 70 years ago. The station is proud of its collection (one of the world's largest) of fruit trees.

Mineral and Natural resources of the republic include oil, gas, gold, silver, mercury, wolfram, building materials.

New economic relations brought about joint-stock companies (17), joint-stock banks, joint ventures and increasing ties with foreign countries, France, Germany, Austria, Italy, Britain including. Adygheya exports machines, various types of reduction gears, furniture, cardboard, seeds of oil- yielding plants and food. Major import items are mechanical engineering products, consumer goods, ferrous metals and petroleum products.

\section{Exercises to the text}

Ex. I. Be sure to read the following words, mind the reading of the underlined part.

Picturesque, ancient, archeological, foreign, barrow, mysterious, fauna, resources, reservoir, unique, mountaineering, engineering, group, rout, route, knight, night.

Ex. II. Letter-A-can be read as [ei] [a:] [o:] [عə][ae][๖]. Write out one or 2 examples per each case.

Ex. III.

a) Write out derivatives from the following words. Give the situations they are used in the text.

Invade, territory, picture, settle, legend, test, depend, mountain, engine, reduce, pass, process, favour, count, govern, source, nature. 
b) Translate the following word combinations. Give the situations they are used in the text.

Silk route, rock shelters, fruit tree, petroleum product, food processing, climate conditions, poultry farming, water resources, mechanical engineering products.

c) What is the meaning of the following words in the text.

1. To place - класть (помещать); 2. to remain - оставаться; 3. to name -называть по имени; 4. the channel - канал, пролив; 5. the account - отчёт; 6. the first - первый; 7. to direct - направлять; 8. to part - расставаться; 9. a square - площадь; 10. to number насчитывать; 11. to water - поливать; 12. to crop - коротко стричь; 13. to venture осмелиться, рискнуть; 14. once - раз; 15. item - вопрос, пункт повестки дня.

Ex. IV. Write out synonyms for the following words. Give the situations from the text.

Whole - весь, explain - объяснять, famous, foe - враг, medicinal -лечебный, soldier - воин, солдат, waterfowl - водоплавающие птицы, enigmatic - загадочный, famous for, circumstances - условия, profusion - изобилие, conqueror - завоеватель, across - через, series of - некоторое количество (ряд), twelve, damp - влажный, to found - основывать (создавать), regenerate - возрождать, land - земля, stretch простираться.

\section{Ex. V. Express in one word.}

1. Stone - built tombs, 2. a long hard journey, 3. climbing mountains (as a sport), 4. mound, dating from prehistoric times. 5. all animals of an area or an epoch, 6. all the plants of a particular area or period, 7. something that gives safety or protection, 8. way (in) to a place, 9. system of rules and principles that has been accepted by society or a class or a group of people, 10. supreme law-making council or assembly, 11. stretch of water joining two seas, 12. yearly (season's) produce of grain, grass, fruit, 13. large domestic fowl (hens, ducks, geese, turkeys).

\section{Ex. VI. Translate into English using active vocabulary of the text.}

1. Республика славится уникальными минеральными источниками, используемыми в лечебных целях, 2. Природные данные, благоприятные для скалолазания, слалома (катания на лыжах), серфинга являются идеальными условиями для развития туризма и создания сети санаториев и лечебниц. 3. Помимо нефти и газа в Адыгее имеется ряд других полезных ископаемых, месторождений различных металлов и строительных материалов. 4. По фауне и флоре Адыгея является одним из интереснейших районов России. 5. Горы Адыгеи являются открытым древним музеем природы.

\section{Ex. VII. Answer the questions.}

1. Where is Adygheya situated? 2. How were the Adyghes called in the middle ages? 3. Why did the north-western Caucasus attract people in ancient times? 4. Did the geographical position of Adygheya influence the mode of life of its inhabitants through the history of their existence? 5. When did Adygheya become a republic? 6. What can you tell about the climate and the rivers of the republic? 7. What can be created and developed in Adygheya owing to its natural facilities? 8. What kind of country is Adygheya from ihe 
economic point of view? 9. What are the main Agricultural branches of Adygheya? 10. Do new economic relations in Russia influence the economy of the republic? 11. What are the main items of Republic's import and export?

Ex. Vlll. Translate into English.

\section{Майкоп}

Административным центром республики Адыгея с 1990 года является Майкоп, расположенный в живописной долине по обоим берегам реки Белой.

Первое упоминание о Майкопе в официальных русских документах относится к 3 июля 1823 года. Позже это имя было дано крепости, закладка которой была начата в 1857 году. После 1864 года население Майкопа выросло благодаря выходцам (переселенцам) из глубинных губерний России. И только в 1870 году Майкоп стал городом.

Сегодня Майкоп является местом богатых археологических и исторических памятников, памятников культуры, архитектуры и градостроительства. Около 7 источников минеральной воды, пять здравниц функционируют в городе. Большинство учреждений науки, культуры и образования находятся в Майкопе. В них входят Национальный Музей Адыгеи, Северо-Кавказский филиал государственного музея Востока, национальная библиотека республики, 2 научно-исследовательских института, 2 вуза и большое число колледжей и профессионально-технических училищ.

Майкоп - член Союза Российских городов. Здесь 8 постоянных представительств Москвы, Краснодарского края, республик Северного Кавказа.

Для жителей Майкопа самое любимое место отдыха - это лесной хребет на левом берегу реки Белой. Здесь открывается изумительный вид на долину реки Курджипс. Видна заснеженная цепь Кавказских гор и плато Лаго-Наки. Хорошо побродить по лесу, осмотреть город с высоты птичьего полета, полюбоваться его прямыми широкими улицами, куполами церквей, заводскими трубами. Майкоп красив и великолепен в любое время года.

\section{Grammar Exercises}

Ex. I. Use one of the given word combinations in each sentence (go skiing, go shopping, go swimming, go riding, go boating).

1. John lives by the sea and he's got a boat, so he often ... . 2. There is plenty of snow in the mountains so we'll be able to .... . . 3. It was a very hot day, so we ... in the river. 4. Margaret has got two horses. She often ... . 5. The shops are shut now. It's too late to .... .

Ex. II. Complete the sentences. Each time use only one word in the form of gerund.

1. It's a waste of money things you don't need. 2. Each time I spend about an hour the newspaper. 3. What's Carol doing? She's busy letters. 4. I think you waste too much time television. 5. There is a beautiful view from that hill. It is worth to the top. 6. It was a lovely day, so I suggested 
Ex. III. Use the Infinitive or the Gerund of the given verbs.

1. a) They failed ... the problem.

b) Ann succeeded in ... the problem

c) He insisted on ... the problem

2. a) Marry wanted ... me a drink

b) Marry promised ... me a drink

c) Marry insisted on ... me a drink

3. a) I am thinking of ... away next week.

b) I am hoping to ... away next week.

c) I am looking forward to ... away next week.

to solve

to buy

to leave

Ex. IV. Use the words in brackets to make up a sentence with:

a) afraid

1. I don't usually carry my passport with me (I, to be afraid, lose, it).

2.The sea was very rough (we, to be afraid, go, swimming).

3. We rushed to the station (we, to be afraid, miss, our train).

4. I don't like the look of the food on my plate (I, to be afraid eat, it), (I, to be afraid, make, myself, ill)

b) sorry

I. Sorry (keep) you waiting. 2. I'm sorry for (shout) at you yesterday. 3. I'm sorry for (say) what I said yesterday. 4. I've failed my exam. Oh? I'm sorry (hear) that.c) c) used

1. We used (to live) in a small village but now we live in London. 2. Tom used (to drink) a lot of coffee. Now he prefers tea 3. Jane had to get used (to drive) on the left. 4 . I feel very full after that meal. Im not used to... (to eat) so much. 5. Im the boss here! Im not used to (be told) what to do.

d) prefer

1. I prefer (to write) letters to (to phone) people. 2. I would prefer (to eat at home) rather than (to go) to a restaurant.

\section{Ex. V. Make up sentences using the given word combinations.}

1. To be afraid of: forget your address, to be late to the concert, catch cold. 2. There is no hope of: to see him soon, he to finish the work in time. 3. I heard of: he to be ill, he to be sent abroad. 4. Thank you for (I am grateful to you for): to come, to answer my letter, to invite. 5. I can't afford: to buy a car, to waste much time on such trifles. 6. ...insisted on: to stay at home, to send the letter immediately. 7. Excuse me for ... . 8. What is the use of ... . 9. They were in the habit of ... . 10. We shall look forward to ... .

Ex. VI. Translate the sentences into English using one of the above written verbs.

1. succeed in + герундий удаваться

2. insist on $+\quad$ настаивать

3. think of $+\quad$ думать

4. dream of $+\quad$ мечтать

5. approve of $+\quad$ одобрять

6. feel $($ like $)+\quad$ (не) хочется

7. look forward to + с нетерпением ждать 
8. Я с нетерпением жду встречи с ней.

9. Некоторые родители не одобряют, что их дети смотрят (a lot of) много телевизор.

10. Нам потребовалось много времени (a long time), но в конце концов

(finally) нам удалось решить проблему (solve the problem).

11. Я всегда мечтал жить в маленьком домике у моря (by the sea).

12. Я хотела приготовить обед сама (by myself), но Джейн настояла на том, чтобы помочь мне.

13. Я думаю заняться бизнесом.

14. Мне что-то не хочется выходить сегодня (to go out).

Ex. VII. Translate into English using one of the given verbs in each sentence.

to congratulate + дополнение + предлог + герундий

accuse of - обвинять, forgive for - простить, suspect of - подозревать, thank for благодарить, worn against - предупреждать, to stop from - чтобы не.

1. Я поздравила подругу со сдачей экзамена. 2. Они не поверили мне и обвинили меня во лжи (в том, что я лгу) (tell lies). 3. Пожалуйста, прости (меня), что долго не писала тебе. 4. Его заподозрили в шпионаже (to be a spy). 5. Сожалею, но я не смогу прийти на вечеринку. Спасибо за приглашение. 6. Я предупредил тебя вчера не пить холодную воду. 7. Вокруг лужайки (lawn) был забор (fence), чтобы люди не ходили по траве (on the grass). 


\section{ГРАММАТИЧЕСКИЙ СПРАВОЧНИК}

\section{Имя существительное}

\section{Множественное число существительных}

I. Множественное число существительных образуется при помощи окончания - $s$ или - еs, если основа существительного оканчивается на: s, ss, sh, $x$, ch.

Окончание множественного числа читается:

[s] после глухих согласных

$$
\text { a map - maps, a grant - grants }
$$

[z] после звонких согласных и гласных

a girl-girls, a boy - boys

[iz] после шипящих и свистящих

a box - boxes, a bench - benches Орфографические изменения:

-у- меняется на -i- и прибавляется -es, если перед -у- стоит согласная, но: а boy - boys

- $\boldsymbol{f}$ - меняется на-v- и прибавляется -es

a calf-calves, a wife - wives

Окончание - es во множественном числе принимают также существительные, оканчивающиеся на - о-: Echoes, heroes, Negroes

Однако следующие существительные принимают только окончание - s:

a) существительнье, оканчивающиеся на -о- с предшествующей гласной:

bamboo - bamboos, kangaroo - kangaroos;

б) сложносокращенные слова:

kilos, photos, memos;

в) музыкальные термины:

concertos, pianos, solos;

c) имена собственные:

Philipinos, Eskimos.

II. Некоторые существительные сохранили древнеанглийскую форму образования множественного числа:

а) изменение корневой гласной во множественном числе:

a man [mæn] - men [men]

a woman [wumən] - women ['wimin]

a tooth [tu: $\theta] \quad-$ teeth $[t i: \theta]$

afoot [fut $] \quad-$ feet [fi:t] 
a mouse [maus] - mice [mais]

a louse [laus] - lice [lais]

a goose [gu:s] - geese [gi:s];

б) при помощзи - $\boldsymbol{n}$ :

child-children, an ox-oxen;

в) некоторые существительные не имеют отдельной формы множественного числа:

1. Названия определённых животных, птиц и рыб:

олень -a deer

рябчик -a grouse

скумбрия -a mackerel

камбала -a plaice

лосось -a salmon

овца -a sheep

свинья -a swine

форель - a trout

2. Слово craft в значении - судно, самолёт.

3. Существительное, обозначающее человека или людей этой национальности. Эти существительные оканчиваются на звук [s] или [z] a hundred Vietnamese, Chinese, Japanese, Swiss, Portuguese.

III. Слова, заимствованные из латинского, греческого, французского сохранили форму множественного числа исконного языка:
a) $\quad$ um $\rightarrow a$
a datum
-data
a curriculum
-curricula
a millennium
-millennia
a phylum
-phyla

б)

$$
u s \rightarrow \quad i ; \text { era (ora) }
$$

a nucleus ['nju:kliəs] -nuclei [njurkliai]

a radius ['reidjos] -radii [reidiai]

'genus

- genera,

'corpus

- corpora

в) $\quad$ is $\rightarrow \quad$ es

a crisis ['kraisis] -crises [kraisi:z]

an a'nalysis -analyses

basis -bases 
r) $a \quad \rightarrow \quad$ ae [i:]

a 'formula formulae

'nebula -nebulae

'chela -chelae

д) $\quad$ on $\rightarrow a$

phenomenon -phenomena

e) $\quad$ ex $(i x) \rightarrow$ ices

'index - indices

ap'pendix -appendices

ж) аи $\quad \boldsymbol{a u} \rightarrow \boldsymbol{x}$

bureau - bureaux [bjue'rouz]

Множественное число сложных существительных

Сложные существительные, второй элемент которых существительные, множественного числа не имеют:

homework, moonlight, sunshine

В сложных существительных, первый элемент которых man или woman форму множественного числа принимают обе части:

$$
\begin{gathered}
\text { a manservant-menservants, } \\
\text { women students, women drivers }
\end{gathered}
$$

В словах типа man-hole, woman-hater форму множественного числа принимает последнее существительное, так как основной смысл слова - во второй части:

$$
\begin{gathered}
\text { man - holes } \\
\text { woman-haters } \\
\text { woman-folks }
\end{gathered}
$$

В сложных существительных, состоящих из существительного + предлог или предложное словосочетание, окончание множественного числа принимает первое существительное:

lookers-on, passers-by, grants-in-aid, men-of-war

В сложных существительных, состоящих из глагола или прилагательного + предлог, окончание множественного числа принимает последний элемент:

grown-ups, pullovers, lay-bys, sit-ins

Существительное, оканчивающееся на суффикс $-\boldsymbol{f u l}$, имеет традиционную тенденцию образования множественного числа:

$$
\text { bucketfuls, spoonfuls }
$$




\section{Артикль}

Артикль - определитель имени существительного. В английском языке два артикля: неопределённый артикль $\boldsymbol{a}(\boldsymbol{a n})$ и определённый the

\section{Неопределённый артикль}

Неопределённый артикль употребляется перед существительными в единственном числе:

1. Когда впервые упоминается предмет, явление, выраженное существительным; I see a book on your table. I was given the book to read.

2. Перед существительными, являющимися именной частью составного сказуемого: My sister is an engineer.

3. Перед существительным, имеющим описательное определение:

This is an interesting book.

4. После слов what, such, quite, rather перед исчисляемыми существительньми: He is quite an expert in this field.

5. Перед существительными, обозначающими число, вес, меру, время:

I go to the library once a week.

6. После оборота there is, выражающего неопределённость:

There is a book on the table.

\section{Определённый артикль}

Определённый артикль употребляется перед существительными в единственном и во множественном числе:

1. Когда о предмете, явлении, выраженном этим существительным, говорилось раньше:

I bought a book yesterday. The book is very interesting.

2. Когда из контекста, ситуации ясно, о каком предмете, явлении идёт речь:

It's stuffy in the room. Open the window.

3. Перед прилагательными в превосходной степени, которые являются определением к этому сущзествительному:

He is the brightest student in the group. 
4. Перед порядковым числительным:

The first of May.

5. Перед названиями рек, морей, горных изепей, искусственных каналов, пустынь:

The Black Sea. the Urals, the Pacific Ocean.

6. Перед названиями болезней:

My sister is not well. Is it the flue?

7. Перед названиями кораблей:

R. Scott led the National Antarctic Expedition in the "'Discovery"

8. Перед существительными, обозначающими единственные в своем роде предметы: The North, the Earth, the Sun.

9. Перед названиями газет:

"The Times"

10. Перед названиями отелей, ресторанов, театров, кинотеатров, музеев, галерей:

The "Brigantina", the Bank of England, the Tower of London.

11. Перед прилагательным или Participle II (причастием прошедшего времени) в значении существительного в единственном числе:

the rich, the poor, the besieged

12. Определённый артикль употребляется перед сущуествительными, обозначающими имя собственное:

a) перед фамилией, когда подразумевается вся семья:

The Ivanovs, the Robinsons

$\boldsymbol{b})$ перед собственным именем, которое, говорящий хочет выделить из всей группы собственных имён:

That's not the George Lamb I knew. Этого Джоржа Лэмб я не знал.

Это не тот Джорж Лэмб, которого я знал.

The London of 1665 was far smaller than the London of today.

Артикль не употребляется:

1. Перед вещественными существительными: bread, milk, coffee.

I don't like my tea with milk.

2. Перед существительными breakfast, lunch, dinner, supper в сочетании с глаголом to have.

I was having dinner when he came. 
3. Перед названиями дней недели.

The first day of the week is Monday.

4. Перед существительным class в значении <занятие>, если нет определения.

After classes I usually go for a walk.

5. Перед существительным time в сочетании It's time to go to bed.

6. Перед существительными: English, French, German - английский, французский, немецкий язык.

I can speak English.

7. Перед lesson, если после него количественное числительное.

Lesson 2 is on Page 10.

8. Перед University, если перед ним стоит имя собственное.

Most external students at London University are living in London.

9. Перед существительными home, school, college с предлогом at.

He is at home now.

10. Перед названиями учебных предметов и отраслей науки.

Our Institute trains teachers of History (Psychology).

11. Перед $\boldsymbol{T V}$ - с глаголом to watch.

He is fond of watching TV.

12. Перед названиями спортивных игр в сочетании с глаголом play, to play hockey, to play football.

13. Перед названиями улиц, площадей, парков, станций метро и аэропортов, а также магазинов, ресторанов, отелей, банков, церквей в честь основателей.

Red Square, St. James's Park, Kennedy Airport, St. Paul's Cathedral, Lloyd Bank, British Airways, Buckingham Palace.

14. Перед существительными morning, day, evening:

a) в функции сказуемого и иногда дополнения;

б) в сочетании с предлогами: at, by, from .

15. Перед названиями стран, континентов, городов (но если название страны нарицательное, то перед ним употребляется определённый артикль.

England, Canada, but: the United States of America, the United Kingdom of Great Britain and Northern Ireland 


\section{Притяжательный падежс существительных}

Существительное в английском языке имеет два падежа - общий (the Common Case) и притяжательный (the Possessive Case).

Притяжательный падеж обозначает принадлежность. На письме он обозначается 's (апостроф и $s$ ) после существительных единственного числа и после существительных множественного числа, не имеющих окончания множественного числа:

\section{the bird's nest, my sister's book}

МH. Ч.

the children's toys;

после существительных множественного числа с окончанием -s-, притяжательный падеж обозначается только ' (апострофом).

\section{The students' papers}

The birds' nests

Существительное в притяжательном падеже предшествует существительному в общем падеже и является определением к нему.

Только одушевлённые существительные употребляются в притяжательном падеже. Неодушевлённые существительные употребляются в притяжательном падеже в следующих случаях:

1. Если существительное подразумевает группу людей:

Africa's future, the country's needs

2. Существительное обозначает промежуток времени, расстояние, вес и стоимость:

Однодневный отдых

Сегодняшняя программа

Через месяц

Расстояние в две мили

\section{a day's rest}

today's programme

in a month's time

two miles' distance 


\section{Местоимение}

\section{Личные местоимения}

Личные местоимения имеют два падежа.

Именительный падеж

$\begin{array}{cc}\text { Ед. число } & \text { Мн. число } \\ \boldsymbol{I} & \text { We } \\ \text { You } & \text { You } \\ \text { He } & \text { They } \\ \text { She } & \\ \text { It } & \end{array}$

В предложении эти местоимения выполняют функцию подлежащего.

I am a first-student. She shares the room with two more students.
Объектный падеж

$\begin{array}{cc}\text { Ед. число } & \text { Мн. число } \\ \text { Me } & \text { Us } \\ \text { You } & \text { You } \\ \text { Him } & \text { Them } \\ \text { Her } & \\ \text { It } & \end{array}$

Эта форма личных местоимений в предложении может быть дополнением I often met them on my way to the Institute.

\section{Притяжательные местоимения}

зависимая форма
my book
your book
his book
her book
its book
our books
your books
their books

независимая форма
mine
yours
his
hers
its
ours
yours
theirs

В предложении зависимая форма выполняет функцию определения. Независимая форма местоимений употребляется без существительного и в предложении может выполнять функции подлежащего, дополнения и именной части сказуемого.

\section{Неопределенные местоимения}

Some - употребляется только в утвердительных предложениях.

Any - - употребляется в вопросительных и отрицательных предложениях.

No - - употребляется только в отрицательных предложениях.

Аутлева Ф.А., Читао Н.A., Хатхе А.А., Симбулетова Р.К. 
Все эти местоимения могут сочетаться со словами: one, body, thing. Такие производные местоимения пишутся слитно, кроме по оne, ударение на первом слоге. Эти же местоимения могут соединяться с - where. Образованные таким способом обстоятельства часто употребляются со словом else.

Местоимение и его производные могут употребляться и в вопросительных предложениях:

1. В вопросах, на которые последует утвердительный ответ "yes".

What's wrong? Have you got something in your eye?

2. В вопросах, выражающих просьбу или предложение?

Would you like something to eat? Can I have some sugar?

Местоимение "any" употребляется:

1. после " if"

If there are any letters for me, can you send them on to this address.

2. когда смысл предложения отрицательный. Hе refused to eat anything (т.е. он не ел ничего) (didn't eat anything). Somebody, someone, anybody, anyone - кто-нибудь

something, anything - - что-нибудь

no one, nobody - никто

nothing - ничего 


\section{Прилагательное}

\section{Степени сравнения}

1. Односложные и двусложные прилагательные с ударением на первом слоге (оканчивающиеся на -у, $-\boldsymbol{e r},-\boldsymbol{o w}$ ) образуют сравнительную степень при помощи суффикса - er, а превосходную при помощи суффикса -est:
large -
larger -
the largest
happy -
happier -
the happiest
big -
bigger -
the biggest
narrow -
narrower -
the narrowest

2. Многосложные прилагательные образуют степени сравнения при помощи слов: more, most
important -
more important -
the most important

Таким же способом образуют степени сравнения прилагательные: like, real, tired

3. Некоторые прилагательные образуют степени сравнения от разных основ:

\begin{tabular}{|c|c|c|}
\hline $\begin{array}{l}\text { good - } \\
\text { bad } \\
\text { ill }\end{array}$ & $\begin{array}{l}\text { better - } \\
\text { worse- }\end{array}$ & $\begin{array}{l}\text { the best } \\
\text { the worst }\end{array}$ \\
\hline far & $\left\{\begin{array}{l}\text { farther - } \\
\text { further - }\end{array}\right.$ & $\begin{array}{l}\text { the farthest (расстояние) } \\
\text { thefurthest (порядок) }\end{array}$ \\
\hline old & $\left\{\begin{array}{l}\text { near - nearer } \\
\text { older } \\
\text { elder }\end{array}\right.$ & $\begin{array}{l}\text { the nearest (the next) } \\
\text { the oldest } \\
\text { the eldest }\end{array}$ \\
\hline te & $\{$ later & the latest \\
\hline & less & $\begin{array}{l}\text { the lattest } \\
\text { the least }\end{array}$ \\
\hline
\end{tabular}

Для сравнения двух предметов одинакового качества используется парный союз as ... as:

This book is as interesting as that one.

При сравнении предметов неодинакового качества используется союз not so ... as:

I would prefer the less expensive book.

Английские сравнительные предложения, содержащие конструкцию: the .. the переводятся на русский язык чем ...тем.

The more you read the more you know. 


\section{Усиление степеней сравнения прилагательных}

Сравнительная степень имен прилагательных может быть усилена с помощью наречий: much, far, still (значительно, гораздо, ещё).

Превосходная степень усиливается с помощью наречия by far (гораздо, значительно, намного).

The London of 1665 was far smaller than the London of today.

\section{Порядок прилагательных перед существительным:}

1. Прилагательное, обозначающее размер, длину предшествует прилагательному, обозначающему форму и ширину:

a small round table, a long narrow street, a tall but very graceful woman

2. Прилагательное, обозначающее возраст, следует после эпитета;

\section{a handsome young man}

3. Прилагательное, обозначающее цвет, следует за прилагательным, обозначающим возраст:

$$
\text { a dirty old brown hat }
$$

4. Прилагательному, обозначающему национальность (происхождение), предшествует прилагательное, обозначающее цвет:

\section{a beautiful green Chinese carpet}

5. Прилагательное, обозначающее вещество, из которого сделана вещь (предмет), стоит перед определяемым существительным:

\section{How big}

2. How old

3. What colour

4. Where from

5. What is it made of

\section{a blue and white silk tie}




\section{Числительное}

\section{Количественные числительные}

Количественные числительные, обозначающие единицы:

$\begin{array}{ll}\text { one } & \text { six } \\ \text { two } & \text { seven } \\ \text { three } & \text { eight } \\ \text { four } & \text { nine } \\ \text { five } & \text { ten }\end{array}$

Количественные числительные от 13 до 19 образуются от соответствующих единиц при помощи суффикса -teen, на который падает ударение.
11 eleven
12 twelve
13 thirteen
14 fourteen
15 fifteen
16 sixteen
17 seventeen
18 eighteen
19 nineteen

Числительные, обозначающие десятки от 20 до 90, образуются при помощи суффикса -ty, который прибавляется к числительному, обозначающему единицы: two - twenty, three - thirty, four - forty, five - fifty, six - sixty, seven - seventy, eight eighty, nine - ninety.

Количественные числительные 100 - a hundred, 1000 - a thousand, 1000000 - a million не принимают окончания $-\boldsymbol{s}$, если им предшествует числительное.

The population of London is about 9 million people.

Если эти числительные употребляются как существительные, то они принимают окончания множественного числа, а следующие за ними слова вводятся предлогом - of: thousands of students.

\section{Порядковые числительные}

Порядковые числительные образуются от соответствующих количественных при помощи суффикса $-\boldsymbol{t h}$, кроме числительных $1^{\text {й }}, 2^{\text {й }}, 3^{\text {й }}$. 
Перед порядковым числительным употребляется определённый артикль.

one - the first, two - the second, three - the third, four - the fourth,

five - the fifth, six - the sixth, seven - the seventh, eight - the eighth.

nine - the ninth, twenty - the twentieth, forty-one - the forty-first

\section{Дробные числительные \\ Простые дроби}

Числитель простых дробей - количественное числительное, а знаменатель порядковое числительное.

$\frac{1}{6}-$ one sixth $\frac{1}{2}-$ a half $\frac{1}{4}-$ a quarter

Если числитель простой дроби больше единицы, то порядковое числительное в знаменателе принимает окончание множественного числа. Существительное, следующее за простой дробью, употребляется в единственном числе с предлогом - of

$\frac{2}{3}$-two thirds of a kilometre, но $2 \frac{1}{2}-$ two and a half tons.

Существительное, следующее за целым числом или смешанным, употребляется во множественном числе без предлога. 24.75 - two four point seven five tons

\section{Десятичные дроби}

В десятичных дробях целое число отделяется от дроби точкой, которая читается point [point]. Каждая цифра читается отдельно.

3.04 - three point nought [no:t] four

0.25 - nought point twenty five (or two five)

Проценты обозначаются: 2\% или two per cent

В телефонных номерах каждая цифра читается отдельно.

98-4-41 - nine eight double four one

98-1-06 - nine eight one o (ou) six

Ноль в английском языке может читаться:

1. nought [no:t] - nought, one, two, three, four и в десятичной дроби

four

2. 0 [ou:] в телефонных номерах, при обозначении года 98-1-04 - nine eight one о

3.zero ['zirou] - при обозначении температуры и в математике

4. nil [nil] or nothing - в футболе Dynamo won 4-0 four nil (four to nothing)

5. love - в теннисе

Ivanov leads by 30:0 (thirty love)

Иванов ведет со счётом 30:0. 
Чтение хронологических дат и времени

at 5 - at five (o'clock)

at 5.15 - at five fifteen или at a quarter past five

5.30 - at five thirty или at half past five

5.50 - at five fifty, at ten to six

5 May 1990 (British English)

May $5^{\text {th }} 1990$ (American English)

On the fifth of May, nineteen ninety

On May the fifth

On May fifth 


\section{Глагол}

Глагол в английском языке имеет три вида - неопределённый (Indefinite), продолженный (Continuous) и совершенный (Perfect).

3 времени - настоящее (Present), прошедшее (Past) и будущее (Future);

2 залога - действительный (Active Voice) - страдательный (Passive Voice);

2 наклонения - изъявительное и сослагательное.

При употреблении в предложении английский глагол может выступать как:

1. Смысловой глагол (простое глагольное сказуемое)

I do my morning jerks every day.

2. Модальный глагол (составное модальное глагольное сказуемое).

I must finish the work in time.

3. Глагол-связка (составное именное сказуемое).

In autumn leaves turn red and gold.

I am a first-year student.

4. Вспомогательный глагол. Самостоятельного значения он не имеет. В сочетании со смысловым глаголом образует простое глагольное сказуемое.

The text was translated by one student.

I have just translated the text.

\section{Повелительное наклонение}

Повелительное наклонение выражает приказание или просьбу, побуждение к действию или запрещение, которые могут быть переданы в утвердительной или отрицательной форме. Глагол в повелительном наклонении для второго лица единственного и множественного числа по форме совпадает с инфинитивом без частицы - to.

Read the text once more.

Go and fetch a piece of chalk, please.

Отрицательная форма образуется при помощи вспомогательного глагола $\boldsymbol{d o}$ и отрицательной частицы $\boldsymbol{n o t}$.

\section{Don't be late.}

Форма повелительного наклонения для всех остальных лиц образуется при помощи: глагола let + личного местоимения в объектном падеже (him, her, us, them $)+$ инфинитива смыслового глагола без частицы - to. 
Let him read the text once more. Let us discuss the question now. Глагол let может переводиться - позвольте, разрешите, можно, пусть.

\section{Модальные глаголы}

Модальные глаголы показывают отношение говорящего к действию, выраженному смысловым глаголом (возможность, способность, необходимость совершения действия). Они также называются недостаточными, так как они не имеют неличных форм глагола (инфинитива, причастия, герундия), не изменяются по лицам, числам, (в третьем лице единственного числа не имеют окончания), образуют вопросительные и отрицательные формы без вспомогательного глагола.

\section{Can}

Модальный глагол can выражает умственную, физическую возможность выполнить действие, возможность или невозможность выполнить действие в силу обстоятельства.

I can speak, read, write English.

I can't carry this bag, it is too heavy.

В Past Indefinite глагол can имеет форму - could.

I could not go to the Institute yesterday as I was ill.

В тех случаях, когда глагол can не может употребляться, его заменяют эквивалентом - to be able to

I shall be able to finish the work in time.

Глагол can выражает сомнение в предложениях типа:

Не can't be at home now. Нe может быть, чтобы он был дома сейчас.

Can he know Chinese so well? Неужели он знает китайский так хорошо?

May

Этот модальный глагол выражает возможность выполнить действие в силу разрешения.

You may take any book you like. Вы можете взять любую книгу, которая вам нравится.

Форма Past Indefinite глагола may - might, эквивалентом глагола may являются сочетания to be allowed, to be permitted. May может выражать предположение. В этом случае он переводится - возможно, может быть.

\section{Must}

Модальный глагол must выражает долженствование - должен, нужно, надо. Глагол must имеет только форму настоящего времени и два эквивалента - to be to - если действие 
заранее запланировано, ожидаемо; to have to, который переводится - пришлось. Он употребляется, когда действие необходимо выполнить в силу обстоятельств.

He is to come at five. I had to work hard last month. Why did you have to work so hard? I was to take five exams.

Глагол must может выражать предположение, граничащее с уверенностью.

He must be at home now. Он, (должно быть) вероятно, дома сейчас.

\section{Времена неопределённого вида \\ (Indefinite Tenses)}

Времена этого вида обозначают:

I. Действительный факт, неопровержимую истину.

II. Часто повторяющиеся действия.

III. Последовательность действий.

I. Present Indefinite образуется от инфинитива смыслового глагола без частицы to и без личных окончаний во всех лицах, кроме третьего лица единственного числа. Глагол-сказуемое в Present Indefinite в 3 лице единственного числа принимает окончание $-\boldsymbol{s}(\boldsymbol{e s})$.

Единственное число:

$\left.\begin{array}{l}\text { I } \\ \text { He } \\ \text { She }\end{array}\right\}$ is $\quad \begin{array}{lll}\text { do, } & \text { study, } & \text { finish } \\ \text { does, } & \text { studies, } & \text { finishes }\end{array}$

\section{Множественное число:}

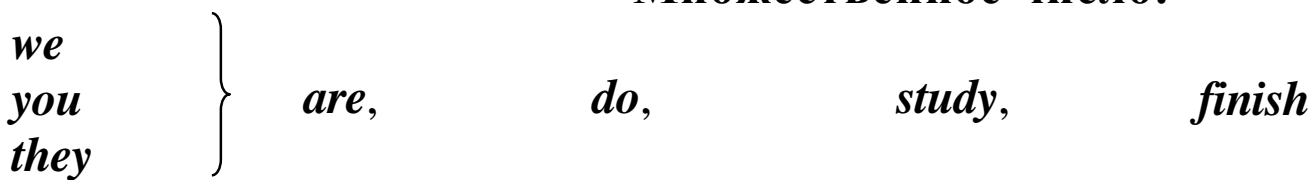

He is an employee. He has a lot of English books. He often works in the library. We go to the library twice a week.

Обстоятельство в предложениях с глаголом-сказуемым в Present Indefinite выражено наречием неопределённого времени:

часто - often

всегда - always

обычно - usually

или словосочетаниями: every day (week, Monday), once a week (year), twice a month.

Вопросительные и отрицательные предложения образуются при помощи вспомогательного глагола do (does), который в вопросительных предложениях стоит перед подлежащим.

Do you study at the Institute?

В отрицательных предложениях вспомогательный глагол и отрицательная частица not стоят после подлежащего.

I don't live at the hostel. 
II. Past Indefinite правильных глаголов образуется при помощи суффикса -ed, который читается:

$[t]$ - после глухих согласных

[d] - после звонких согласных и гласных

worked, finished

[id] - после звуков /t/,/d/

$$
\text { answered, played }
$$

divided, invited

Орфографические изменения, происходящие в глаголе при прибавлении суффикса-еd:

a) permit - permitted, prefer-preferred

but: visit - visited, suffer-suffered;

б) label-labelled, quarrel-quarrelled, signal - signaled;

в) глаголы на -ic в Past Indefinite принимают букву $-\boldsymbol{k}$ : panic-panicked, picnic-picnicked.

Неправильные глаголы можно условно разделить на 3 группы по образованию формы Past Indefinite:

1. Глаголы, имеющие одну и ту же форму в Present Indefinite, Past Indefinite, и Past Participle: cut, put, hit, let, cast, burst, spread.

2. Глаголы, в которых одинаковы формы только в Past Indefinite, $n$ в Past Participle:

to hear-heard, heard; to leave - left, left;

to feel-felt, felt; to have - had, had;

to catch-caught, caught; to bring - brought, brought.

3. Глаголы, имеющие различные формы и в Past Indefinite, и в Past Participle:

to write - wrote, written; to begin - began, begun; to give - gave, given.

Обстоятельство в предложении в Past Indefinite выражено наречием - yesterday и словосочетаниями last year (month, week), a year ago, 2 years ago.

Вопросительные и отрицательные предложения образуются при помощи вспомогательного глагола - did.

Did you live at the hostel last year?

Did they go to the library yesterday?

III. Future Indefinite образуется при помощи вспомогательных глаголов - shall для 1 лица единственного и множественного числа, и will - для всех остальных лиц.

I shall graduate from the Institute in 5 years.

В предложениях со сказуемым в Future Indefinite обстоятельство выражено: наречием - tomorrow, словосочетанием с next, и предлогом in- через.

I shall finish this work in an hour. 


\section{Времена продолюенного вида}

Они обозначают длительное действие, происходящее в момент речи или в определённый отрезок времени. Формула образования сказуемого - вспомогательный глагол to be в соответствующем времени и Present Participle (причастие настоящего времени) смыслового глагола.

\section{Present Continuous}

I am reading $\underline{\text { now }}$

He is

She

reading at this moment

$\left.\begin{array}{l|l}\begin{array}{l}\text { We } \\ \text { You } \\ \text { They }\end{array} & \begin{array}{r}\text { are reading } \\ \text { I } \\ \text { He } \\ \text { She }\end{array}\end{array}\right\} \begin{aligned} & \text { Past Continuous } \\ & \text { was reading at that moment }\end{aligned}$

We

You

They

I

We

were reading when he came

Future Continuous

shall be reading at this moment

$\left.\begin{array}{l}\text { He } \\ \text { She } \\ \text { You } \\ \text { They }\end{array}\right\}$

will be reading when he comes

Вопросительные предложения:

Is your sister reading in the library now?

What is your sister reading now?

Is she reading a book or a magazine?

Your sister is reading in the library, isn't she?

Отрииательные предложения:

I am not reading. She is not waiting for her sister.

\section{Времена совершенного вида}

Этот вид обозначает действие, закончившееся к определённому моменту речи. Формула образования сказуемого: вспомогательный глагол to have в соответствующем времени и Past Participle (причастие прошедшего времени) смыслового глагола.

Aутлева Ф.А., Читао И.А., Хатхе А.А., Симбулетова Р.К. 


\section{Present Perfect}

может употребляться, когда обстоятельство времени выражено наречиями:

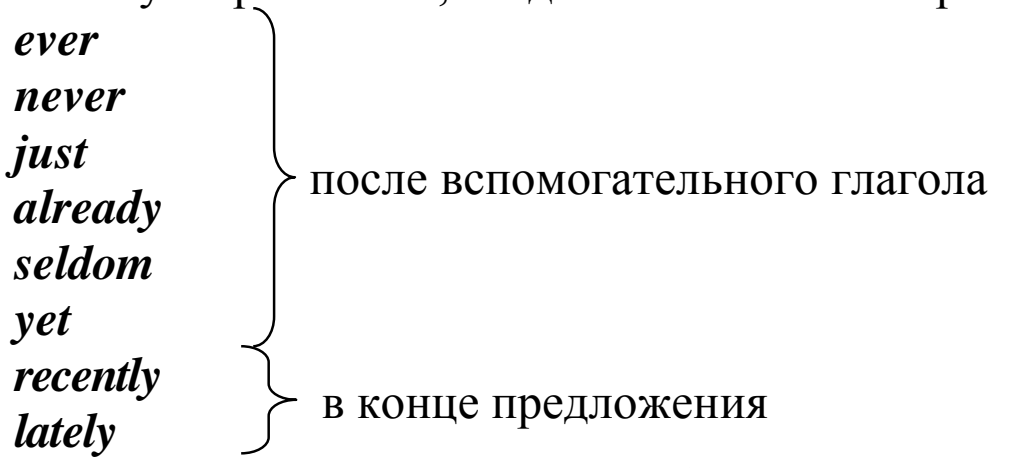

I have never seen this man.

She has just finished the work.

и словосочетанием с предлогом for - в течение или since - с. Глагол-сказуемое в таких предложениях часто переводится настоящим временем.

We have known each other for 2 years (since our childhood).

Мы знаем друг друга 2 года (с детства).

I have already finished the work.

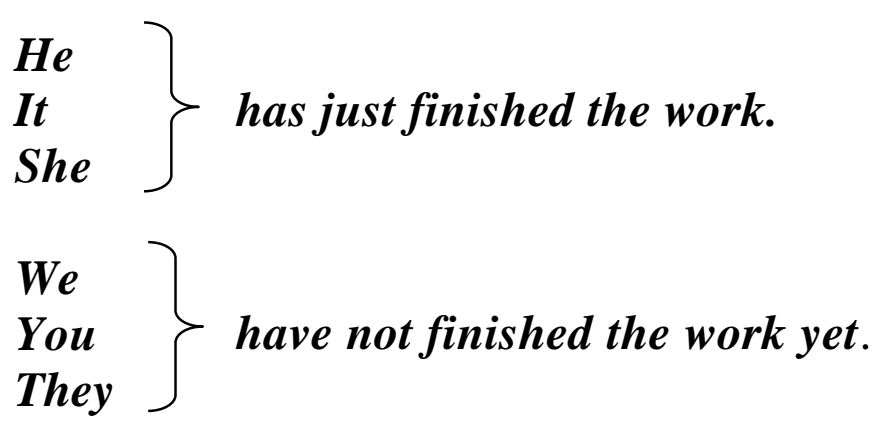

\section{Past Perfect}

выражает действие, закончившееся до начала другого действия или указанного момента в прошлом, и часто вводится союзами: after, when, before предлогом by.

I had finished the work before he came I (she, he, it, we, you, they) had finished the work by 5 o'clock yesterday (when he came).

В вопросительных предложениях вспомогательный глагол have (has, had) ставится перед подлежащим.

Where have you been all this time?

Why have you put on your coat? It's warm today.

\section{Future Perfect}

обозначает действие, которое закончится к определенному моменту в будущем или до начала другого действия. Глагол-сказуемое образуется при помощи вспомогательного глагола have в Future Indefinite (shall have, will have) и Past Participle смыслового глагола.

I (we) shall have finished the work by 5 o'clock tomorrow.

You, (he, she, they) will have finished the work after we come.

Обстоятельство выражено словосочетанием с предлогом by или другим действием в Present Indefinite. 


\section{Страдательный залог}

Страдательный залог обозначает, что действие производится над действующим лицом, а не выполняется им.

Формула образования - вспомогательный глагол to be в соответствующем времени и виде и Past Participle смыслового глагола.

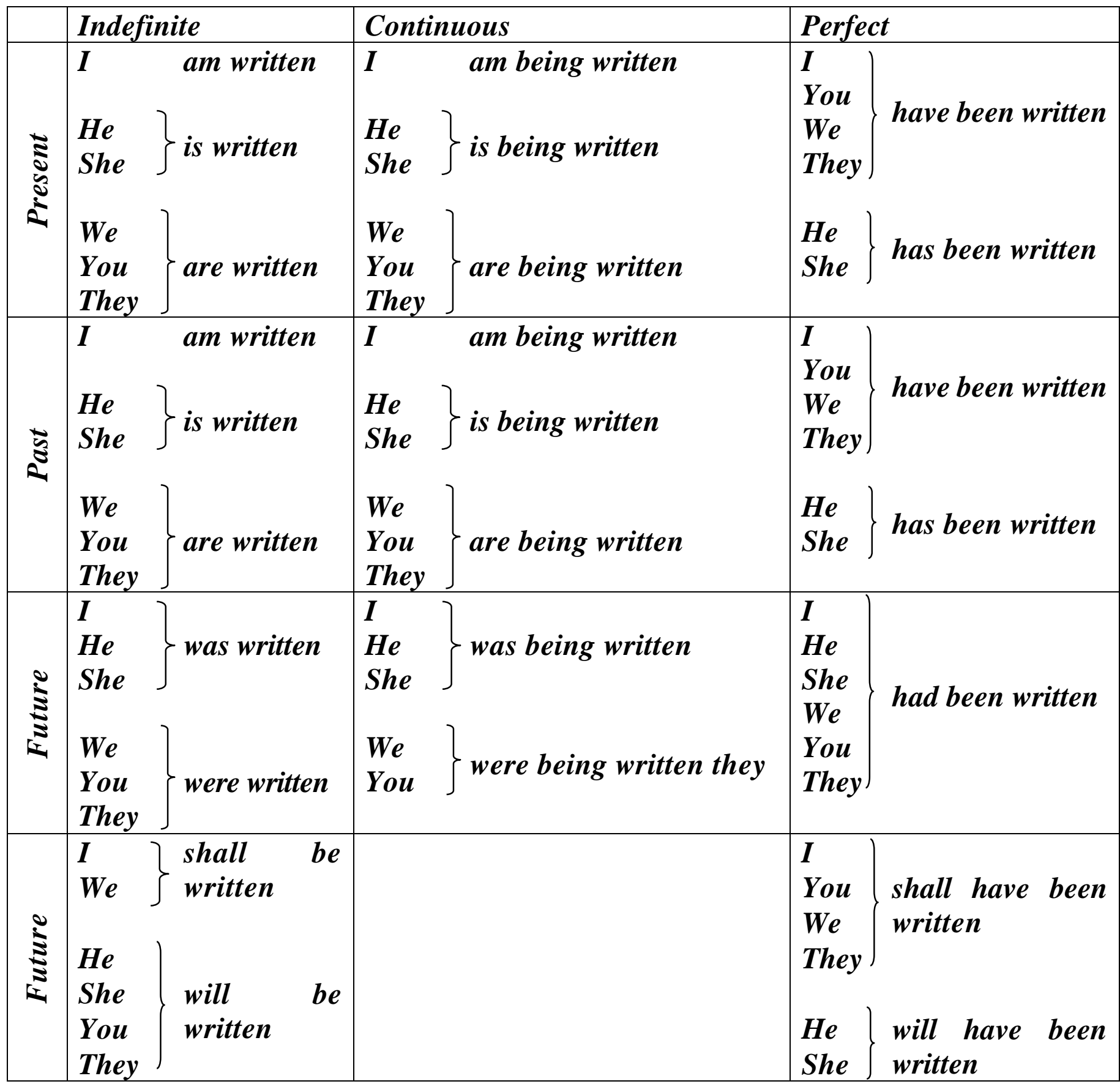




\section{Способы перевода на русский язык}

1. $\quad$ Глагол - быть - плюс краткая форма причастия.

This house was built last year.

Этот дом был построен в прошлом году.

2. Неопределенно-личными предложениями.

One more kindergarten is being built in our street.

На нашей улице строят еще один детсад.

3. Глаголами на-ся-.

Gerrald Durrel's books are read with great interest.

Книги Даррела читаются с большим интересом.

Если указывается, кем или чем производится действие, то употребляется существительное с предлогами $\boldsymbol{b} y$ или with, выражающими отношение творительного падежа. В английском языке подлежащим пассивной конструкции может быть:

1. прямое дополнение

The book was given to her.

2. косвенное дополнение

She was given the book.

3. предложное дополнение. При этом предлог ставится непосредственно после смыслового глагола.

The doctor was sent for a few minutes ago.

Перевод такой конструкции следует начинать с предлога.

За доктором послали несколько минут назад. 


\begin{tabular}{|l|l|}
\hline \multicolumn{1}{|c|}{ Личные формы } & \multicolumn{1}{|c|}{ Неличные формы } \\
\hline $\begin{array}{l}\text { 1. К личным формам относятся } \\
\text { формы глагола в трёх лицах } \\
\text { единственного и множественного числа } \\
\begin{array}{l}\text { во всех временах действительного и } \\
\text { страдательного залога. }\end{array}\end{array}$ & $\begin{array}{l}\text { 1. К неличным формам относятся: инфинитив } \\
\text { the Infinitive }) \text { причастие (the Participle }) \\
\text { герундий (the Gerund })\end{array}$ \\
\hline $\begin{array}{l}\text { 2. В предложении всегда служат } \\
\text { сказуемым и употребляется при } \\
\text { наличии подлежащего. }\end{array}$ & $\begin{array}{l}\text { 2. Самостоятельно они не служат } \\
\text { сказуемыми; они выражают действия без } \\
\text { указания лица, числа и наклонения. В } \\
\text { предложении они могут выполнять функции } \\
\text { подлежащего, определения, обстоятельства, } \\
\text { части сказуемого. }\end{array}$ \\
\hline $\begin{array}{l}\text { 3. Выражают грамматические } \\
\text { категории: лицо, число, время, залог, } \\
\text { наклонение. }\end{array}$ & $\begin{array}{l}\text { 3. Они не выражают грамматические } \\
\text { категории лица, числа, наклонения, поэтому } \\
\text { неличные формы не спрягаются }\end{array}$ \\
\hline
\end{tabular}

\section{Причастие настоящего времени}

(Present Participle)

Это неличная форма глагола, имеющая особенности глагола и прилагательного. Образуется причастие от основы глагола при помощи суффикса-ing

\begin{tabular}{|c|c|c|}
\hline $\begin{array}{l}\text { 1. если основа глагола оканчивается } \\
\text { На -е-, то буква - е- опускается. } \\
\text { Но: }\end{array}$ & $\begin{array}{l}\text { sing } \\
\text { take } \\
\text { write } \\
\text { singe } \\
\text { dye }\end{array}$ & \begin{tabular}{|l} 
singing \\
taking \\
writing \\
singeing \\
dyeing
\end{tabular} \\
\hline $\begin{array}{l}\text { 2. Буква - у- сохраняется вне зависимости от } \\
\text { того, какая буква перед ней. }\end{array}$ & $\begin{array}{l}\text { play } \\
\text { study }\end{array}$ & $\begin{array}{l}\text { playing } \\
\text { studying }\end{array}$ \\
\hline 3. Буквосочетание- $\boldsymbol{i}$ - меняется на - у-. & $\begin{array}{l}\text { lie } \\
\text { die }\end{array}$ & \begin{tabular}{|l|} 
lying \\
dying
\end{tabular} \\
\hline $\begin{array}{l}\text { 4. Конечная согласная в односложном глаголе } \\
\text { и двусложном (если ударение падает на 2- ой } \\
\text { слог) удваивается, если ей предшествует } \\
\text { краткая гласная. }\end{array}$ & begin & $\begin{array}{l}\text { beginning } \\
\text { occurring }\end{array}$ \\
\hline $\begin{array}{l}\text { 5. Глаголы, оканчивающиеся на -ic-, } \\
\text { имеют в форме на -ing- окончание -icking. }\end{array}$ & \begin{tabular}{|l} 
panic \\
traffic
\end{tabular} & $\begin{array}{l}\text { panicking } \\
\text { trafficking }\end{array}$ \\
\hline $\begin{array}{l}\text { 6. Конечные буквы -1- и -р- удваиваются в } \\
\text { Британском английском, но не в Американском } \\
\text { варианте. }\end{array}$ & $\begin{array}{l}\text { label } \\
\text { signal }\end{array}$ & \begin{tabular}{|l} 
labelling \\
signalling
\end{tabular} \\
\hline
\end{tabular}


Как глагол Participle имеет формы времени и залога.

\begin{tabular}{|l|l|}
\hline \multicolumn{1}{|c|}{ Active Voice } & \multicolumn{1}{c|}{ Passive Voice } \\
\hline $\begin{array}{l}\text { Present Participle }- \text { writing } \\
\text { Perfect Participle }- \text { having written }\end{array}$ & $\begin{array}{l}\text { being written } \\
\text { having been written }\end{array}$ \\
\hline
\end{tabular}

В предложении причастие настоящего времени может быть:

1. определением.

The reading student is a good sportsman.

The student sitting at that table is our monitor.

На русский язык причастие в этой функции переводится причастием на -ущ-, -ющили определительным придаточным предложением.

2. частью сказуемого:

а) простого глагольного (времена Continuous);

He is translating the text without a dictionary.

б) составного именного;

She is charming. The book is interesting.

в) составного глагольного сказуемого после глаголов, выражающих движение come, run, go.

On seeing his mother the child came running.

3. обстоятельством. В этой функции причастие может употребляться с союзными словами when и while. На русский язык Present Participle в этой функции переводится обстоятельственным придаточным предложением или деепричастием.

Being my friend he helped me a lot.

Так как он был моим другом, он много помогал мне.

While doing the exercise he made some mistakes.

Выполняя упражнение, он сделал несколько ошибок.

\section{Сложные конструкции с причастием настоящего времени}

После глаголов, выражающих восприятие органов чувств, желание, причастие настоящего времени может употребляться в функции сложного дополнения в сочетании с существительным или личным местоимением в объектном падеже.

\section{I heard them speaking in the library.}

На русский язык такое простое предложение переводится сложноподчинённым предложением с придаточным дополнительным.

Я слышал, как они разговаривали в библиотеке. 


\section{Независимый причастный оборот}

Иногда причастие I может иметь своё подлежащее в предложении, помимо главного подлежащего, которое согласуется с глаголом-сказуемым:

\section{My friend being ill, I went to see him.}

Так как мой друг болен, я пошёл навестить его.

Такая конструкция называется "независимый причастный оборот". Он может стоять в начале главной части предложения или в конце её и отделяться запятой. Оборот, стоящий в начале предложения, переводится обстоятельственным придаточным предложением.

The weather being fine, we went for a walk.

Так как погода была хорошая, мы пошли гулять.

Если причастный оборот стоит в конце предложения, то он переводится сложносочинённым предложением, которое вводится союзами $a, u$, причём.

There is always water vapour in air, the amount depending on various conditions.

В воздухе всегда присутствуют водяные пары, причём количество их зависит от разных условий.

\section{Причастие прошедчего времени (Past Participle)}

Причастие прошедшего времени правильных глаголов образуется так же, как в Past Indefinite при помощи суффикса -ed, который читается так:

$$
\begin{aligned}
& \text { [t] - (the) finished (story) } \\
& \text { [d] - (the) closed (shop) } \\
& \text { [id] - (the) defeated (army) }
\end{aligned}
$$

В некоторых глаголах происходят орфографические изменения, когда они принимают суффикс -ed в Past Participle. способами:

1.Неправильные глаголы (нестандартные) образуют Past Participle разными

а) без изменения неопределенной формы глагола:

$$
\text { cast, cut, put, hit, burst; }
$$

б) изменением формы в Past Indefinite и Past Participle:

$$
\text { to leave - left, left; to teach-taught, taught. }
$$


В предложении причастие II может быть:

\section{1. Определением}

The injured man was taken to hospital.

Причастие II в этой функции часто употребляется с отрицательной приставкой -un: Antarctica is an uninhabited continent.

В сочетании со словами well, badly, half причастие II становится сложным словом. This is a half-finished work (Job)

Если нет соответствующего глагола, то суффикс $-\boldsymbol{e d}$ - может присоединяться к существительному. Такое слово имеет обычно определение:

a blue-eyed baby

a long-legged animal

an absent-minded man

\section{2. Частью сказуемого:}

a) простого глагольного со вспомогательным глаголом - to be - во временах страдательного залога:

The dictation was written without a single mistake.

со вспомогательным глаголом - to have во временах группы Perfect;

I have just finished the translation;

б) составного именного

\section{I am interested in the art of healing.}

\section{3. Обстоятельством.}

Иногда перед причастием в этой функции могут стоять предлоги или союзные слова: if, when, whenever, after, before, since.

I will gladly come to your house if (when, whenever) invited.

После предлогов: before, after, on, in, since,by причастие прошедшего времени употребляется с глаголом - being.

After being invited, I have been told the party was cancelled.

После глагола have причастие прошедшего времени может употребляться в функции сложного дополнения в сочетании с существительным или местоимением.

I must have (get) my hair cut. 


\section{Герундий}

(The Gerund)

- неличная форма глагола, имеющая особенности существительного и глагола. Образуется он при помощи окончания - ing, которое прибавляется к основе глагола.

to sing - singing, to lie - lying

to begin - beginning, to singe - singing

Как глагол, герундий имеет формы времени и залога.
Active Voice
Passive Voice
Indefinite Gerund - writing
- being written
Perfect Gerund - having written
- having been written

Как существительное герундий может быть:

\section{1). Подлежащим:}

\section{Reading is useful.}

На русский язык герундий переводится существительным или инфинитивом.

Читать полезно.

Чтение полезно.

\section{2). Частью сказуемого:}

a) составного именного:

His favourite occupation is reading.

Его любимое занятие - чтение.

б) составного видового глагольного сказуемого после глаголов, выражающих начало, продолжение или конец действия (begin,start, continue):

\section{I began reading some minutes ago.}

в) составного глагольного после глаголов, имеющих модальное значение - can't help, to intend, to try, to attempt

\section{3). Дополнением:}

а) прямым дополнением после глаголов:

$$
\begin{aligned}
& \text { избегать - avoid } \\
& \text { задержать - delay } \\
& \text { откладывать - put off, postpone } \\
& \text { возражать - mind } \\
& \text { прощать - excuse }
\end{aligned}
$$

The book is worth reading.

а также глаголов, требующих или герундий или инфинитив to like, to deslike, to hate, to prefer, to remember, to forget и выражений: can't bear, can't afford

б) предложным дополнением:

после глаголов типа: to think of, to rely on, to thank for, to depend on, to prevent from или после прилагательных, причастий $u$ существительных, производных глаголов и прилагательных - to be fond of, tired of, proud of, hope, intention, necessity, possibility. 
Thank you for coming.

4). Определением после существительных типа: risk, habit, idea, method, way, custom

\section{He gave up the habit of smoking.}

5).Обстоятельством. В этой функции герундий всегда употребляется с предлогом.

He left the room without saying good-bye.

Герундий по форме совпадает $c$ причастием настоящего времени, но имеет отличительные признаки в различных функциях.

\section{Сравнительная таблица функций герундия и причастия}

\begin{tabular}{|l|l|}
\hline \multicolumn{1}{|c|}{ Герундий } & \multicolumn{1}{|c|}{ Причастие настоящего времени } \\
\hline 1. Подлежащее & 1. Не может быть подлежащим \\
\hline 2. Часть составного сказуемого & 2. Часть простого сказуемого \\
\hline $\begin{array}{l}\text { 3. Дополнение (с существительным в } \\
\text { притяжательном падеже или } \\
\text { притяжательным местоимением). }\end{array}$ & $\begin{array}{l}\text { 3. Дополнение (с личным местоимением } \\
\text { в объектном падеже). }\end{array}$ \\
\hline 4. Определение (чаше с предлогом). & 4. Определение (без предлога). \\
\hline 5. Обстоятельство (всегда с предлогом) & 5. Обстоятельство (без предлога) \\
\hline $\begin{array}{l}\text { 6. На русский язык чаще переводится: } \\
\text { существительным, инфинитивом }\end{array}$ & $\begin{array}{l}\text { 6. На русский язык чаще переводится: } \\
\text { прилагательным, причастием, } \\
\text { деепричастием. }\end{array}$ \\
\hline $\begin{array}{l}\text { 7. Ударение падает на герундий } \\
\text { boiling-point } \\
\text { changing - room } \\
\begin{array}{l}\text { living-room } \\
\text { a bathing costume } \\
\text { writing paper. }\end{array}\end{array}$ & $\begin{array}{l}\text { 7. Ударение на обоих словах } \\
\text { long-playing } \text { record } \\
\text { hard - working student } \\
\text { fast } \text { - moving traffic }\end{array}$ \\
\hline
\end{tabular}




\section{Инфинитив}

- неличная форма глагола, имеющая особенности существительного и глагола. Как глагол, инфинитив имеет формы времени и залога.

\begin{tabular}{|l|l|l|}
\hline \multicolumn{2}{|c|}{ Active Voice } & \multicolumn{1}{c|}{ Passive Voice } \\
\hline Indefinite Infinitive & to write & to be written \\
\hline Infinitive & Continuous Infinitive & - \\
Infinitive & to be writing & \\
\hline Perfect Infinitive & to have written & to have been written \\
\hline
\end{tabular}

Показателем инфинитива является частица - to. Но часто инфинитив употребляется без неё:

1. после модальных глаголов.

Can you give me a lift to the airport?

2. после выражений had better, would rather, would sooner, might just as well. If you feel unwell you had better take some medicine.

3. после глагола let.

Let us go to the cinema.

4. после глагола know в Perfect Tenses.

I have never known him lose his temper.

5. после глагола-make в значении заставлять.

\section{Hot weather makes me feel tired.}

Но если эти глаголы в страдательном залоге, то инфинитив после них употребляется с частицей

Функции в предложении:

\section{1. Подлежащее}

It is useful to read much.

\section{2. Часть сказуемого:}

To read much is useful.

a) составного именного

My aim is to master English.

б) составного модального глагольного

Soho is the district where one can see people of different types.

в) составного видового глагольного после глаголов, выражающих начало, продолжение или конец действия (begin, start, go on, keep on, continue, finish)

\section{3. Дополнение}

после глаголов, выражающих приказание, просьбу, разрешение, восприятие органов чувств: to ask, to allow, permit, to help, to forget, to prefer, to like, to be afraid.

I am sorry to be late. 


\section{4. Определение}

часто после the first, the second, the next, the last, the only.

Here is the article to be translated.

Вот статья, которую нужно перевести.

(для перевода).

I was the only one to arrive on time.

В этой функции инфинитив имеет модальный оттенок. Переводится на русский язык:

1) определительным придаточным предложением, выражающим долженствование, возможность или будущее время;

2) существительным с предлогом или существительным в родительном падеже.

He was the first to answer.

Он был первым, кто должен отвечать (он отвечал первым).

\section{5. Обстоятельство;}

а) цели

I've come to help you.

To know English well one must work hard.

б) следствия после наречий too, enough, sufficiently: I was too tired to go for a walk.

\section{Сравнение инфинитива и герундия}

Advise, recommend, encourage, allow, permit, forbid

глагол + дополн. + to глагол + ing

She didn't allow us to smoke. Where would She doesn't allow smoking in the house the you recommend me to go for my

holiday?

\section{Remember}

Please remember to lock the door.

I clearly remember saying locking the door

Пожалуйста, не забудь запереть дверь.

Я точно помню, что запер дверь.

\section{Regret}

We regret to inform you that we are unable I regret saying what I said. I shouldn't have to offer you the job.

Сожалеем, но приходится сообщить (сказать, информировать) said it.

Я сожалею, что сказал это. Мне не следовало говорить.

\section{Go on}

After discussing the economy the minister

The minister went on talking for 2 hours. went on to talk about foreign police.

Делать или говорить что-то новое

I was very tired. I tried to keep my eyes open but I couldn't.

Попробовать что-либо сделать сделать, приложить усилие.

\section{Try}

Продолжать делать то же самое.

The device doesn't seem to be working. Try pressing the green button.

Попытаться что-либо сделать ради эксперимента. 


\section{Need}

I don't need to come to the meeting, do I? He needs to work harder if he wants to make progress. I (he, we, you, they) need to do something.
My jacket needs cleaning. The problem needs thinking about.

Some thing needs doing.

\section{Prefer}

I prefer to drive rather than travel by train. I prefer driving to travelling by Train. Prefer to do something rather than.

\section{Help}

Prefer doing something to doing something.

I can help you do the washing. Can you help me move this table?
She tried to be serious but couldn't help laughing.

Interested, surprised, delighted, sorry for

+ to (hear, see. know, read, learn)

+ предлог. + ing

I was interested to hear that your niece has I am interested in buying a car. got a new job.

To be afraid

+ to do something потому что опасно, вредно, холодно

+ ing, боюсь упасть (простудиться, опоздать)

A lot of people are afraid to go out at night

Sorry

The path was icy so we walked very carefully. We were afraid of falling потому что могли упасть

+to, извиняюсь, прежде чем что-то $+f o r+i n g$ извиняемся за то, что сделано сделаем раньше

I'm sorry to bother you, but I need to talk to Sorry for shouting at you yesterday. you

\section{Used}

+ to + инфинитив

Tom used to drink a lot of coffee. Now he prefers tea.

to be (get) used + to + ing

She was not used to driving on the left. She had to get used to driving on the left.

When we were small children we used to go swimming every day. Do you get a bit lonely sometimes? Yes, I am used to sharing the room with some students. 


\section{ЛИТЕРАТУРА}

1. Аксененко Б.Н. Предлоги английского языка. Упражнения: Пособие для студентов пед. институтов и филол. факультетов ун-тов / Ред. Э.Г. Андреева: худ. ред. В.Б. Михневич; техн. ред. К.И. Беляева; кор-ор Ф.Н. Аврушина. - Л.: Учпедгиз, 1962.

2. Войтенок В.В. Войтенко А.И. Разговорный английский. - М.: Рольф, 1999. $480 \mathrm{c.}$

3. Годлинник Ю.М., Малишевская Е.В., Федосеева Д.А. Пособие по синонимике англ, языка для сту-тов педагогических инс-тов / Ред. Э.Г. Андреева. - Л.: Просвещение, 1965. - 256 с.

4. Клементьева Т.В. Повторяем времена английского глагола. - М: Дрофа, 1995. $208 \mathrm{c}:$

5. Клоуз РА. Справочник по грамматике для изучающих английский язык: Пособие для учителя на анг. языке / Ред. В.И. Синюков. - М.: Просвещение, 1979. $-352 \mathrm{c}$

6. Корнеева Е.А., Баграмова Н.В., Чарекова Е.П. Практика английского языка: Сборник упражнения по устной речи / Ред. А.Н. Драчев. - Спб.: Союз, 1997. - 336 c.

7. Лич Д, Свэртвик Я. Коммуникативная грамматика английского языка: Пособие для учителя на английском языке. - М.: Просвещение, 1983. - 304 с.

8. Эккерсли К.Э. Учебник английского языка: [в 4-х кн.]. - Баку: Изд-во «Азербайджан», 1993. - 330 с.

9. Эльянова Н.М., Лейн М.Д. Некоторые трудности английского языка Лексический справочник: Пособие для ст-дов пед. инс-тов и филол. ф-тов / Ред. И.Б. Комарова. - Л.: Учпедгиз, 1963. - 248 с.

10. Murphy Raymond. English Grammar in Use: A self-study reference and practice book for intermediate students. - Second edition. - Cambridge: University Press, 1994. $-350 \mathrm{c}$

11. Ruppeldiova Jean. British Life and Institutions / Redaktorka Libusa Takacova,Bratislava: VYALO slovenske pedagogecke nakladatel 'stvo, 1967. - 280 c

12. Stankova Elena. English Phonetic Exercises: Учебное пособие / Отв. ред. Е. Наумова. - Sofia.: Naouka i izkoustvo, 1966. - 146 c. 
Аутлева Фатима Аскербиевна

Читао Ирина Айтечевна

Хатхе Асиет Асланбечевна

Симбулетова Римма Казбековна

\title{
УЧЕБНО-МЕТОДИЧЕСКОЕ ПОСОБИЕ
}

\author{
ПО АНГЛИЙСКОМУ ЯЗЫкУ \\ ДЛЯ СТУДЕНТОВ 1-2 КУРСОВ \\ НЕЯЗЫКОВЫХ ФАКУЛЬТЕТОВ
}

ООО «Электронные издательские технологии»

385020, Республика Адыгея, г. Майкоп, а/я 09

e-mail: elit-publishing@yandex.ru

Объем: 3,8 Мб

Подписано к использованию 01.07.2016 г. 